INTER NATIONAL MONETARY FUND
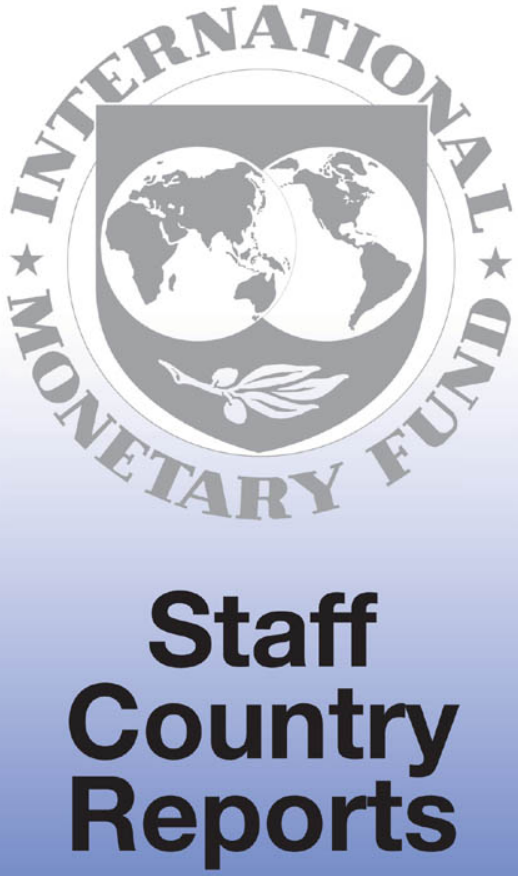


\section{Mongolia: 2002 Article IV Consultation-Staff Report; Public Information Notice on the Executive Board Discussion; and Statement by the Executive Director for Mongolia}

Under Article IV of the IMF's Articles of Agreement, the IMF holds bilateral discussions with members, usually every year. In the context of the 2002 Article IV consultation with Mongolia, the following documents have been released and are included in this package:

- the staff report for the 2002 Article IV consultation, prepared by a staff team of the IMF, following discussions that ended on October 1, 2002, with the officials of Mongolia on economic developments and policies. Based on information available at the time of these discussions, the staff report was completed on October 11, 2002. The views expressed in the staff report are those of the staff team and do not necessarily reflect the views of the Executive Board of the IMF.

- a Public Information Notice (PIN) summarizing the views of the Executive Board as expressed during its October 25, 2002 discussion of the staff report that concluded the Article IV consultation.

- a statement by the Executive Director for Mongolia.

The document listed below will be separately released.

Selected Issues and Statistical Appendix Paper

The policy of publication of staff reports and other documents allows for the deletion of market-sensitive information.

To assist the IMF in evaluating the publication policy, reader comments are invited and may be sent by e-mail to Publicationpolicy@imforg.

Copies of this report are available to the public from

International Monetary Fund - Publication Services

$70019^{\text {th }}$ Street, N.W. - Washington, D.C. 20431

Telephone: (202) 623-7430 • Telefax: (202) 623-7201

E-mail: publications@imf.org Intemet: http://www.imf.org

Price: $\$ 15.00$ a copy

\section{International Monetary Fund}

Washington, D.C. 


\section{INTERNATIONAL MONETARY FUND}

\section{MONGOLIA}

\section{Staff Report for the 2002 Article IV Consultation}

Prepared by the Staff Representatives for the 2002 Consultation with Mongolia

Approved by R. Anthony Elson and Shigeo Kashiwagi

October 11,2002

- The Article IV consultation discussions were held in Ulaanbaatar during December 1-17, 2001 and May 28-June 11, 2002 and in Washington during the Annual Meetings. The staff team met with Finance Minister Ulaan, Bank of Mongolia (BOM) Governor Chulunbaat, other senior officials, and representatives of Parliament, the private sector, trade unions and NGOs.

- The staff team included Messrs. Molho (head), Jang, and Nishigaki (all APD), Dodzin and Hur (PDR), Lueth (EP, FAD), Menshikov (MAE), and Ms. Pollard (assistant, APD). The team was assisted by Mr. Martin, the Fund Resident Representative, and worked closely with the World Bank. Ms. Baasankhu! (OED) attended some of the meetings.

- The last Article IV consultation was concluded in January 2000, and a new PRGF arrangement for Mongolia was approved in September 2001. The 2002 Article $\Gamma V$ consultation was initially planned to be carried out jointly with the first PRGF review. However, the PRGF review discussions have yet to be completed, resulting in a delayed issuance of this report for a stand-alone Article IV consultation.

- Mongolia's macroeconomic data are broadly adequate for surveillance, but there are serious deficiencies in some areas of the real, external, and fiscal sectors.

- A data ROSC module, which assessed Mongolia's data dissemination practices in relation to the GDDS, was published in May 2001, and a fiscal ROSC module was published in November 2001.

- An on-site safeguards assessment of the BOM was completed on March 5, 2002.

- Mongolia has accepted the obligations of Article VIII, Sections 2, 3, and 4 of the Articles of Agreement.

- The authorities intend to publish this report.

- The principal authors of this report are Messrs. Molho and Jang, with substantial inputs from other team members. 


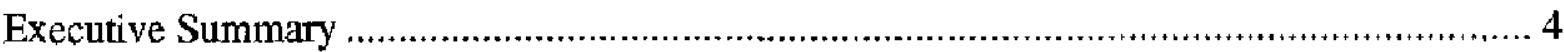

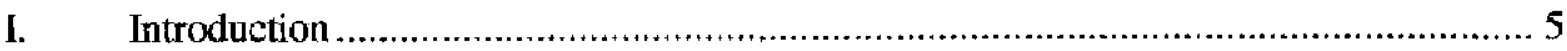

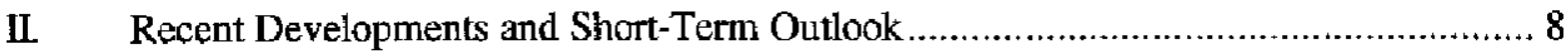

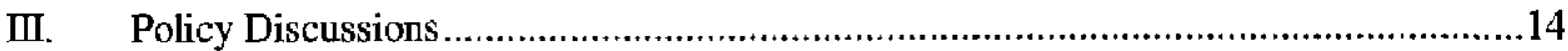

A. $\quad$ Fiscal Policy and Reforms .....................................................................15

B. Monetary Policy and Banking System Reforms ..........................................19

C. External Sector Policies ........................................................................21

IV. Medium-Term Outlook and Debt Sustainability Analysis ......................................23

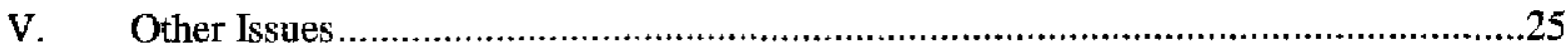

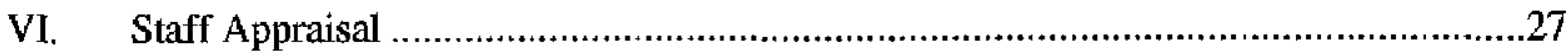

Boxes

1. Performance under Recent PRGF Arrangements ................................................ 6

2. Growth and Recovery During Transition ........................................................... 9

3. Issues in the National Accounts and Trends in Sectoral Growth..............................10

4. Government's Fiscal Reform Agenda and Implications for Fiscal Sustainability.........17

5. External Performance and Short-Run Prospects in an Uncertain Global

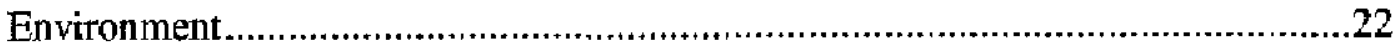

6. Status of Implementation of Measures to Strengthen Statistical Data .........................26

$\underline{\text { Tables }}$

1. Selected Economic and Financial Indicators, 1998-2002 ......................................30

2. Summary Operations of the General Government, 1998-2002 ….........................31

3. Quantitative Performance Criteria and Indicative Targets Under the PRGF

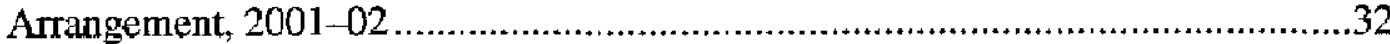

4. Monetary Aggregates, 1998-2002 ....................................................................33

5. Balance of Payments, 1998-2002 …….................................................................

6. External Debt and Debt Service, 2000-07 ........................................................35

7. Structural Benchmarks and Performance Criteria Under the PRGF

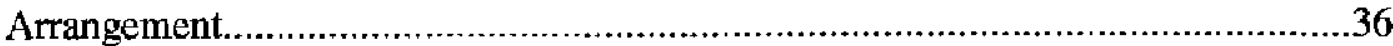

8. Medium-Term Macroeconomic Framework, 1999-2007 ..................................38

9. Fund Position and Indicators of Fund Credit, 2000-07 .............................................39 
$\underline{\text { Figures }}$

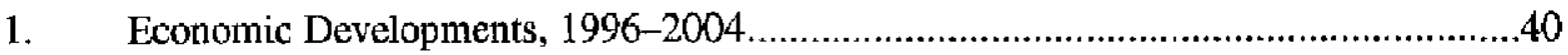

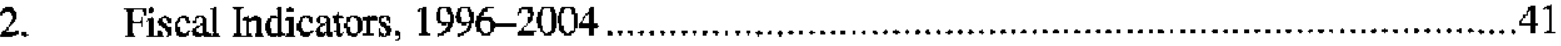

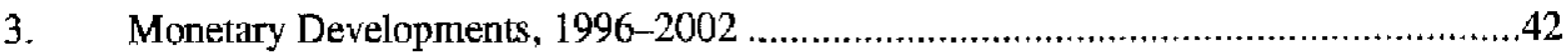

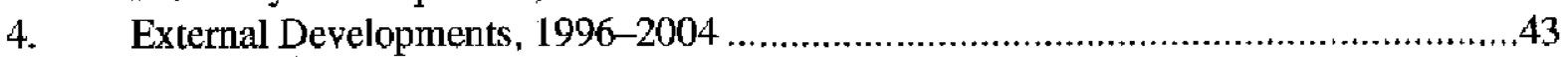

\section{Annexes}

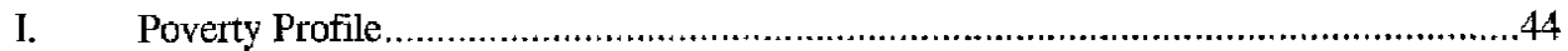

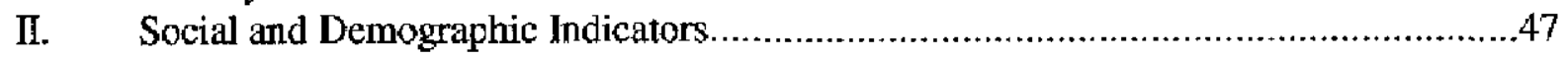

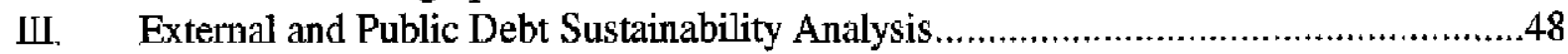

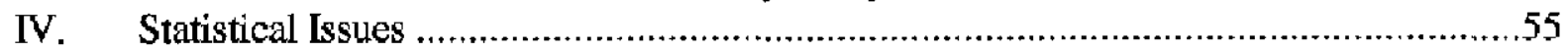

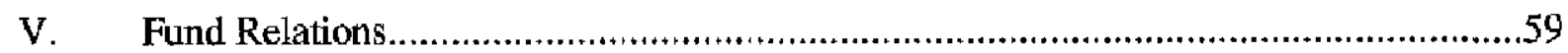

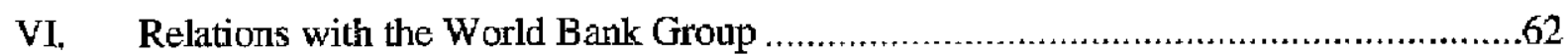

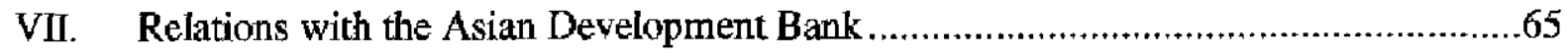




\section{EXECUTIVE SUMMARY}

\section{Background}

- Mongolia has made gond progress since the early 1990s in its transition to a market-based system, but its policy performance under successive Fund arrangements has been mixed, and its prospects for sustainable growth and poverty reduction remain uncertain. With the help of determined efforts to stabilize the macroeconomic situation and introduce basic market institutions, output recovered quickly from the collapse suffered in the early 1990 s. However, weak economic governance has continued to distort incentives for private investment and has posed a threat to fiscal sustainability, as a surge in government expenditure gave rise to a very large build-up of public debt.

- Domestic economic performance has been mixed since the last Article IV consultation. Real GDP growth is estimated to have fallen to about 1 percent a year in $2000-01$, owing to two consecutive harsh winters, which led to large losses in the herd stock. Inflation rose to $11 \frac{1}{2}$ percent in 2000, but it fell back to the single digit range in 2001 and has continued to decline so far in 2002.

- The overali balance of payments has been strong in recent years, but Mongolia's external sustainability has remained under threat. Gross international reserves have remained at a comfortable level since 2000 . However, the stock of post- 1991 external debt remains well above 80 percent of GDP, while the much larger stock of pre-1991 debt to Russia has yet to be resolved.

\section{Policy Issues}

- The overall government deficit was contained in 2000-01 with the help of an extraordinary improvement in revenue performance, but a continued increase in current outlays could lead to an unsustainable widening of the overall government deficit in the period ahead. To protect fiscal sustainability, the authorities have been urged to defer or suspend their plans to grant large civil service wage and pension increases until they are in a position to adopt and implement a comprehensive civil service reform that will protect fiscal sustainability without adversely affecting public investment and the delivery of essential social services for the poor.

- Monetary and credit aggregates have expanded sharply in 2001 and the first half of 2002 . While these developments have not yet had any apparent adverse effects on inflation and the external accounts, the authorities may reed to take more decisive steps to tighten monetary conditions and slow the growth of reserve money in the period ahead.

- Exchange rate nexibility will need to be enhanced to guard against any significant erosion in external competitiveness. To maintain donor and investor confidence, sound macroeconomic policies will need to be complemented with continued prudent external debt management and market-friendly structural reforms.

- The government has recently introduced a number of measures to strengthen fiscal governance, but progress towards reducing the public sector's dominant role in the economy has been slow. The implementation of measures to enhance fiscal transparency and accountability needs to be stepped up in the period ahead, including through improved fiscal data reporting and steadfast implementation of treasury reforms. In addition, the government will need to make faster progress towards rationalizing the civil service, restructuring and privatizing large state-owned enterprises, and establishing a market-friendly trade and investment regime. 


\section{INTRODUCTION}

1. Mongolia has made great strides since it initiated its transition to a market-based system in the early $1990 \mathrm{~s}$, but it continues to face important challenges. With sustained support from the official donor community, determined efforts were launched from the early years of the transition to stabilize the macroeconomic situation and introduce basic market institutions. These efforts led to a quick recovery from the collapse in output suffered in the early 1990s, with the help of significant gains in productivity and robust performance in the newly privatized livestock sector. However, with the government retaining a dominant role in key economic activities, the incentives for private investment remained weak and the recovery was fragile. As the domestic economy was also beset by volatile terms of trade and severe weather conditions in recent years, the prospects for sustainable growth have come under threat, the incidence of poverty remained high, and some indicators of income inequality worsened (Annexes I and $\mathrm{I}$ ).

\section{Mongolia's overall performance under three successive ESAF/PRGF} arrangements approved, respectively, in 1993, 1997, and 2001 has been mixed. On the positive side, the exchange and trade system was liberalized, the Bank of Mongolia (BOM) gradually replenished its stock of international reserves, and the rate of inflation was progressively reduced. However, successive governments have been unable to implement the reforms required to curb unproductive government spending. The adoption of measures to privatize large state-owned enterprises and strengthen the governance of the banking system has also been slow and uneven. In these circumstances, the pressures generated by a large public sector and a generous pension and social insurance system, together with large quasifiscal deficits, led to a ratcheting up of government expenditures in relation to GDP, distorted incentives for pirivate activity, and gave rise to a very large build-up of public debt. This mixed record of performance under Fund arrangements has tended to prevent timely completion of program reviews (Box 1).

\section{The last Articje IV consultation was concluded in January 2000 in conjunction} with the last completed review under the three-year PRGF arrangement approved in July 1997. In concluding the consultation, Directors observed that fiscal consolidation would remain essential to ensure public debt sustainability, and emphasized that the large increase in civil service wage levels implemented under the 2000 budget had to be accompanied by vigorous implementation of public sector administrative reform. They also stressed the need to strengthen tax administration, and encouraged the authorities to pursue reforms that would improve the delivery of government services, rationalize the size of the public sector, and enhance the transparency of its operations. Directors recommended continuation of a tight monetary policy stance to ensure the achievement of program targets for inflation and the external sector. They observed that the market-led depreciation of the exchange rate had 


\section{Box 1. Performance under Recent PRGF Arrangements}

The Executtve Board approved a three-year PRGF arrangement for Mongolia on July 31, 1997. The arrangement envisaged a rapid rechiction in inflation and a build-up of international reserves through monetary and fiscal tightening. The fiscal tightening was to be driven by rapid reductions in unproductive expenditures, with the expenditure-to-GDP ratio expected to be significantly reduced by the end of the program period. Structural reforms were envisaged in a number of areas, including the implementation of a broad-based VAT, elimination of subsidies for public enterprises, liberalization of energy prices, and an aggressive privatization program.

Performance under the first annual arrangement initially exceeded expectatious, but the program reviews could not be completed, as macroeconomic performance deteriorated in 1998. As export commodity prices declined steeply, the external current account shifted into a large deficit, growth slowed, and the exchange rate came under severe downward pressure. Just as budget revenue contributions of the large copper mine (Erdenet) slipped, the government was unable to restrain wage pressures. In addition, large expenditures were necessary to clear arrears on utility bills from the winter of 1997 . Thus, the govemment deficit, excluding privatization receipts, surged to more than 14 percent of GDP in 1998. For its part, the BOM tightened monetary policy and initially tried to maintain a stable exchange rate. While this policy stance resulted in significant reserve losses, it helped keep inflation in check. During the first year of the program, most structural targets were met: energy prices were liberalized, most small to medium-size businesses were privatized, and a VAT was introduced. However, a continued decline in export prices, together with poor management and lax regulatory oversight of the banking system, strained the weak financial position of a number of banks and slowed the reform of the banking system.

The second annual arrangement was approved in mid-1999, following the adoption of a package of measures to bolster fiscal revenues, enhance exchange rate flexibility, and revive the process of bank reform, but policy implementation faltered in the run-ap to the parliamentary elections of mid-2000. Macroeconomic conditions stabilized and reserves rose to more comfortable levels during the second half of 1999. A fresh round of banking sector reforms was also undertaken, with two insolvent banks being put under receivership in December 1999 and slated for closure, while a third (the Agricultural Bank) was slated for restructuring. In the fiscal area, while declining export prices weakened the budget's revenue performance, lower capital expenditures kept the budget deficit broadly on track. The Board completed the first review in early 2000. Thereafter, however, some of the revenue measures introduced in mid-1999 were rolled back, energy prices were again kept at an artificially low level, and there was a large accumulation of budgetary and inter-enterprise arrears. In the meantime, fissures in the three-party government coalition deepened, and the government was unable to secure parliamentary approval for key reform measures in the area of state enterprise privatization. The arrangement lapsed in mid-June and the commitment period expired on July $29,2000$.

The government that took office in August 2000 embarked on a new adjustment program aimed at restoring macroeconomic stability and reinvigorating the reforms required to promote a more rapid pace of private sector led growth and poverty reduction, with support from a new three-year PRGF arrangement approved in September 2001 (EBS/01/160). A key element of this program was to be a sustained fiscal adjustment effort aimed at placing the ratio of public debt to GDP on a clearly declining path while protecting the financing of priority public investment and pro-poor social services. While fiscal consolidation was to be achieved during 2001 primarily by enhancing revenue mobilization, from 2002 onwards, it was to rely on an enduring reduction in lower-priority expenditure. While some progress has been made over the last year towards the introduction of reforms to enbance fiscal transparency and accountability, fiscal sustainability has come under threat as populist measures are under way to raise public wages and pensions beyond what would be affordable. Given a lack of agreement between the authorities and the staff on a fiscal policy framework for 2002 and the medium term and the government's mixed performance in meeting the program's performance criteria to date, the discussions for the first PRGF review have not yet been completed. 
facilitated an appropriate adjustment to the large external terms of trade shock of the late $1990 \mathrm{~s}$, and encouraged the authorities to continue their flexible exchange rate policy while maintaining a sufficient level of international reserves. Directors encouraged the authorities to persevere in their efforts to further strengthen the banking system. In light of little recent change in poverty indicators, Directors encouraged the authorities to refocus their efforts on poverty alleviation, including by developing a Poverty Reduction Strategy Paper (PRSP).

4. The government has taken important steps to implement some of the above recommendations, but performance in a few key areas has been disappointing. In the area of budgetary management, notable efforts are under way to enhance fiscal transparency and accountability, in line with the recommendations of a fiscal ROSC. Steps have also been taken to strengthen tax administration, including by introducing legislation to rationalize intergovernmental tax-sharing arrangements. Reflecting the effects of increases in indirect taxes and intensified collection efforts, revenue growth has risen sharply in recent years. However, the high burden of taxation has reportedly acted as a disincentive to private investment. Moreover, the needed reforms to rationalize the size of the public sector and improve the delivery and targeting of government services to the poor have yet to be adopted. Monetary and exchange rate policies also appear to have deviated from Directors' recommendations, as continued rapid growth in monetary and credit aggregates has been accompanied by a somewhat more rigid exchange rate policy, which could hinder external performance in the period ahead. In the banking system, notable progress has been made towards improving the regulatory and supervisory environment, restructuring the Agricultural Bank, and privatizing the Trade and Development Bank. However, the resulting improvement in indicators of banking system soundness may be threatened by recent trends towards an excessive easing in monetary and credit conditions.

5. The key challenge for the government in the period ahead is to establish a medium-term policy framework that consolidates progress towards macroeconomic stabilization while also creating a more favorable environment for sustainable, pro-poor growth. In the fiscal area, the government's strategy will need to be focused primarily on bringing about a sustained decline in the overall government deficit consistent with public debt sustainability, while also aiming to reorient tax and expenditure policies to make them more pro-growth and pro-poor. Decisive fiscal consolidation should also serve to increase the room for maneuver in the conduct of monetary and excbange rate policies consistent with the need to promote broad-based export-led growth and private sector development. At the same time, emphasis will need to be placed on reforms to enhance public expenditure management and reduce the dominance of the public sector in the economy. These efforts will need to inciude the expedited privatization and restructuring of large state-owned enterprises and utilities, continued efforts to strengthen the regulatory environment in the banking system, and accelerated steps to establish a more market-friendly trade and investment regime. 


\section{RECENT DEVELOPMENTS AND SHORT-TERM OUTLOOK}

6. Domestic economic performance was mixed during $2000-01$ and the first half of 2002, raising questions as to whether the pattern of economic growth recorded during the 1990 s can be replicated in the period ahead. As indicated in Box 2, Mongolia's recovery from the collapse in output suffered in the early years of its transition was driven primarily by the efficiency gains generated by the introduction of market-oriented reforms. These gains were associated in large part with the favorable performance of the livestock sector, which became a principal source of economic growth following its privatization in the early 1990s (Box 3). ${ }^{1}$ Nevertheless, after two consecutive years of summer drought (in 1999 and 2000 ) followed by unusualty harsh winter weather (dzud), the animal husbandry sector and rural incomes have suffered heavy losses in recent years, which have become a drag on overall output performance. Thus, despite a sustained pick-up in domestic demand in the industrial and service sectors, real GDP growth is officially estimated to have fallen to about 1 percent a year in 2000-01 from over 3 percent in 1998-99. ${ }^{2}$ While developments so far in 2002 point to an increase in growth to $3 \frac{1}{2} 2-4$ percent, a recurrence of drought conditions in much of the country over the last few months does not bode well for the performance of the agricultural sector in the period ahead.

7. Mongolia has made good progress towards disinflation in recent years, although the gains in this area may also be difficult to sustain in the period ahead. While the annual average rate of inflation picked up to $11 / 2$ percent in 2000 , as the effects of the weather-related increases in food prices and higher water user fees and energy prices were compounded by a 25 percent general increase in civil service wages, domestic food supplies reverted to a more normal level in 2001 while the togrog remained virtually stable vis-à-vis the U.S. dollar. As a result, inflation fell to 8 percent in 2001 and the pressures on domestic prices continued to recede in the first half of 2002. However, with the real effective exchange rate of the togrog having appreciated by 9 percent since end 1999 in the midst of a deteriorating external environment, the disinflationary influence of developments in traded goods prices may prove difficult to sustain in the period ahead. Moreover, the recent drought conditions may well lead to renewed shortages in food supplies, and a spike in domestic food prices, in the period ahead. In these circumstances, the recent decline in the rate of inflation could be rapidly reversed, especially if there is an extended easing of fiscal and monetary policies.

\footnotetext{
${ }^{1}$ For a more detailed analysis of the sources of economic growth during the 1990 s, see Chapters I and II of forthcoming Selected Issues paper.

${ }^{2}$ The official GDP estimates for 2000-01 are subject to a considerable margin of error, and they may need to be revised downwards once the authorities decide on the methodological treatment of the recent weather-related losses in the herd stock.
} 


\section{Box 2. Growth and Recovery During Transition}

As in many other former socialist economies, a painful "transformational recession" was experienced during the first few years of Mongolia's transition to a market economy in the early 1990s; then the economy recovered as a result of efficiency gains from market-oriented reforms. In fact, both real GDP and capital productivity are estimated to have bottomed out in 1993 and improved afterwards. By 1995, capital productivity had started to surpass jts 1990 level, and by 2001, real GDP had reverted to the level prior to the transition. Labor productivity, however, is still slightly below that of 1990 , possibly reflecting sluggishness in the shedding and reallocation of labor employed in the lower-productivity state-controlled sector of the economy.

Compared with other transition economies, Mongolia's speed of recovery has been moderately high. The cumulative growth of real GDP during 1990-2001 is around 1 percent (compared with highly negative numbers in some other transition economies), and the length of decline before initial recovery during transition is around three years (compared with over four years in some other transition economies). ${ }^{1}$

The sources and pattem of Mongolia's growth during the transition resemble those in most other transition economies. Capital accumulation appears to have been the key engine for economic growth

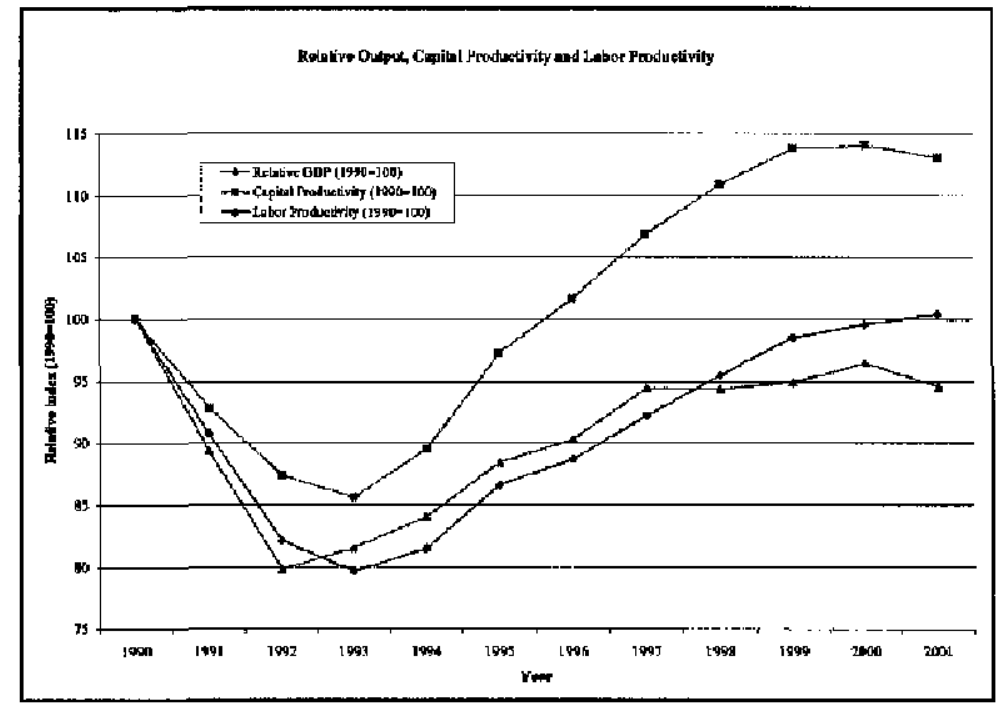
in Mongolia before transition; however, its role diminished following the launching of market-oriented reforms. Similarly, neither education nor employment appears to have made a considerable contribution to economic growth during the transition. Therefore, factor inputs are unimportant explanations for Mongolia's economic growth during the transition, while total factor productivity (TFP) is of paramount importance. In the 1980s, TFP was largely negative, reflecting resource misallocation typical of all planned economies. Then, TFP declined even further at the initial stages of the transition, becoming the primary factor accounting for the collapse in Mongolia's real GDP in the early 1990s. But as the market system developed further, TFP tumed positive for the first time. Hence, consistent with most research findings about other transition economies, efficiency gains, as measured by TFP, are the main factor accounting for the pick-up of growth in Mongolia as the transition took root. With steadfast market-friendly reforms, TFP should be expected to continue to rise over the medium term.

Annualized Output Growth and Its Sources (In percent)

\begin{tabular}{rrrrrr}
\hline Year & Output & Capital & Employment & Education & $T F P$ \\
\hline $1980-84$ & 7.11 & 7.34 & 0.50 & 0.43 & -1.17 \\
$1985-89$ & 5.51 & 4.98 & 2.08 & 0.43 & -1.98 \\
$1990-94$ & -4.99 & -1.60 & -0.24 & 0.43 & -3.58 \\
$1995-2001$ & 2.54 & -0.03 & 0.42 & 0.43 & 1.72 \\
\hline
\end{tabular}

${ }^{\rfloor}$For a detailed comparison with other transition economies, see Chapter 1 in the Selected Issues Paper. 


\section{Box 3. Issues in the National Accounts and Trends in Sectoral Growth}

\section{The treatment of animal losses}

The unusually harsh winters (dzud) experienced by Mongolia for two years in a row in $2000-01$ led to exceptionally large losses in the livestock sector, which bave greatly complicated the derivation of national accounts estimates. The number of lost animals for each of these two years exceeded 10 percent of the beginning-of-year stock. Output of the livestock sector, which accounts for about 25 percent of GDP in Mongolia, has so far been calculated by the National Statistical Office (NSO) as a sum of the value produced in the forms of meat, milk, bair, and skin, and the change in the value of the animal stock. During 2000-01, while the former decreased significantly, the latter became a large negative number, resulting in a big overall decline.

The SNA methodology leaves room for discretion for the treatment of such animal losses in the compilation of GDP data. If the harsh winters are viewed as one-time catastrophic occurrences, then the whole or part of the resulting exceptional losses may be excluded from the calculation of GDP. However, in the case of Mongolia, harsh winters can be expected to occur with some regularity. In addition, the animal losses resulting from adverse weather are not totally exogenous but may also depend on the extent to which herders make adequate preparations to prepare for winter.

In these circumstances, the authorities are considering three options for the methodology to account for animal losses:

- Option A: Distinguish between animals employed as fixed assets (i.e., used for production year after year) and work in progress (i.e., those in the process of being fattened for future slaughter or future employment as productive assets but still in their growth period), and exclude losses of animals employed as fixed assets from the GDP cstimates.

- Option B: Distingujsh between losses that are recurrent or accidental and those that can be deemed as exceptional catastrophic losses, and exclude exceptional/catastrophic losses from the GDP estimates.

- Option C: Treat the losses that occurred in 2000-01 like the losses that occurred in previous years, and adhere to the same national accounts methodology used by the NSO for previous years.

As illustrated below, the GDP growth estimates for $2000-01$ are highly sensitive to the choice from among the three options.

\begin{tabular}{|lrrrr|}
\hline \multicolumn{5}{c|}{ Annual Growth Rates (In percent) } \\
\hline & \multicolumn{3}{c|}{2000} & \multicolumn{2}{c|}{ 2001 } \\
\cline { 2 - 5 } & GDP & Of which: livestock & GDP & Of which: livestock \\
\hline Preliminary official estimates & 1.1 & -15.7 & 1.1 & -18.5 \\
Option A & 3.6 & -8.3 & -1.6 & -24.3 \\
Option B & 1.6 & -14.3 & -1.4 & -26.2 \\
Option C & -1.4 & -22.5 & -5.2 & -42.1 \\
\hline
\end{tabular}

Sectoral composition of growth and implications for the medium term

Mongolia's agricultural sector has historically been an important source of economic growth, accounting for more than half of the growth recorded during the 1990s. Despite the large losses of the livestock sector during 2000-01, a pickup in the growth of the secondary and tertiary sectors is provisionally estimated to have helped keep overall growth at a positive level. Looking ahead, the staff's latest estimates suggest that, on current trends, real GDP could rise by $31 / 2-4$ percent in 2002. Thereafter, if Mongolia's economic policies arc along the lines recommended by the staff, the growth objectives established in the government's I-PRSP ( 5 percent in 2003 and 6 percent in 2004) could be achieved, with the help of sustained strong performance in the secondary and tertiary sectors and resumed growth in agriculture (albeit at more modest rates than in the 1990s). However, the attainment of these objectives could come under threat if the agricultural sector remains more vulnerable in the period ahead than it had been over the last fifty years.

\begin{tabular}{|c|c|c|c|c|}
\hline Contributplon to the grow th (In percest) & $1996-99$ & $\begin{array}{r}\text { Est. } \\
2000 \\
\end{array}$ & $\begin{array}{r}\text { Est. } \\
2001 \\
\end{array}$ & $\begin{array}{r}\text { Proj } \\
2002 \\
\end{array}$ \\
\hline Agriculture, Hunting and Foresiry & 1.9 & -5.8 & -5.9 & 0.1 \\
\hline $\begin{array}{l}\text { Secondary Sector } \\
\text { Mining and Quarrying } \\
M \text { anufacturing }\end{array}$ & $\begin{array}{r}-0.1 \\
0.6 \\
-0.8\end{array}$ & $\begin{array}{r}0.3 \\
0.8 \\
.0 .3\end{array}$ & $\begin{array}{l}2.8 \\
1.1 \\
1.5\end{array}$ & $\begin{array}{l}1.5 \\
0.9 \\
0.5\end{array}$ \\
\hline $\begin{array}{l}\text { Tertiary Seter } \\
\text { Whole szle and retail trade } \\
\text { Hotels and Restaurants } \\
\text { Trsesponi, Storage and Commutiention } \\
\text { Financial Intermediation }\end{array}$ & $\begin{array}{l}1.5 \\
0.6 \\
0.0 \\
0.5 \\
0.0\end{array}$ & $\begin{array}{l}6.6 \\
4.4 \\
0.1 \\
1.9 \\
0.1\end{array}$ & $\begin{array}{l}4.2 \\
2.4 \\
0.1 \\
1.2 \\
0.5\end{array}$ & $\begin{array}{l}2.3 \\
1.0 \\
0.0 \\
0.7 \\
0.3\end{array}$ \\
\hline Real GDP & 3.3 & 1.1 & 1.1 & $\$ 9$ \\
\hline
\end{tabular}


8. Fiscal developments in $2000-01$ were dominated by an unrelenting rise in current expenditure, although the resulting threat to fiscal sustainability was masked by reduced capital expenditures and an extraordinarily rapid growth of revenues. Weak accounting, internal control, and auditing procedures, together with unrealistic budgeting, resulted in large overruns on wages and goods and services, a substantial accumulation of government arrears, and a sharp increase in current expenditures in relation to GDP. ${ }^{3}$ While delays in the implementation of foreign-financed projects served to slow the growth of capital expenditure and net lending, total expenditure rose to about 431/2 percent of GDP in 2001 . However, the increase in spending was more than offset by a sharp increase in revenues, which were bolstered by the full-year effect of the tax measures adopted in mid-1999 and a new package of indirect tax increases adopted in 2001 (including an increase in the VAT rate and a temporary introduction of a 2 percent import duty surcharge), as well as a rebound in commodity export prices during 2000 and improved collection efforts. The overall fiscal deficit (including grants) thus fell from more than 12 percent of GDP in 1999 to about 5\%/2 percent in 2001, while the stock of post-1991 government debt (excluding a much larger stock of unresolved pre-1991 debt to Russia) declined from a peak of 100 percent of GDP in 1999 to 871/2 percent of GDP (60 percent in NPV terms) in 2001 (Tables 1 and 2). However, the pickup in commodity export prices turned out to be temporary, while Mongolia's high tax burden has become a serious disincentive to private activity. In these circumstances, the recent deficit reduction may be difficult to sustain in the absence of decisive action to rein in expenditure pressures.

9. Fiscal developments so far in $\mathbf{2 0 0 2}$ point to a worrisome continuation of recent expenditure trends. With civil service wages and pensions budgeted to increase by 20 percent with effect from October 1, 2002, current expenditure could rise by as much as 1 percentage point of GDP in 2002, after having surged by more than 5 percentage points of GDP in 200001. At the same time, revenue growth is projected to weaken markedly following the removal of the 2 percent import duty surcharge and the decline in profits of the copper mining sector. As a result, on current policy trends, the overall deficit could widen to at least 8 percent of

${ }^{3}$ The recent overruns on wages and goods and services are to a large extent attributable to expenditures by semi-autonomous budget entities in the education and health sectors that have discretion over the use of windfalls in their own revenues. The surge of both revenues and expenditures in relation to GDP since 1999, and their persistent overruns with respect to budget, raise questions about the reliability of the official budgetary data and GDP estimates.

${ }^{4}$ Around 65 percent of Mongolia's external debt (which accounts for 95 percent of total public debt) has been contracted on concessional terms.

${ }^{5}$ The initial budget's expenditure estimates for 2002 as presented in Table 2 understated the increase in spending associated with the higher public wages and pensions by excluding the accounts of 26 budgetary entities in the social sectors slated to be devolved under the government's social sector privatization program. These entities' accounts were reincorporated in the amended budget for 2002 approved in August, as discussed below. 
GDP in 2002, thus placing the NPV of total public debt again on an upward trend in relation to GDP. Moreover, the carry-over effects of the wage and pension increases wonld exert further upward pressure on current expenditure and the overall government deficit in 2003, crowding out public investment and straining the government's limited borrowing capacity. Budgetary developments during the first half of 2002 led to a significant pick-up in net government borrowing from the banking system (Table 3).

10. Monetary and credit aggregates have risen sharply over the last two years, reflecting the combined effects of structural changes in the banking system and a sustained easing of monetary conditions. On the structural front, the rehabilitation efforts following the banking system crises of the 1990 s finally appear to have borne fruit, with a welcome increase in confidence in the banking system apparently leading to reintermediation and a sustained increase in money demand (Box 2, EBS/00/3 and paras. 37-39, Attachment II, EBS/01/166). However, the growth of money and credit also appears to have been fueled by an accommodating monetary policy, as sales of BOM bills have fallen far short of sterilizing the monetary impact of a large increase in the BOM's net international reserves (NIR). As a result, the growth of credit to the private sector surged to 142 percent during 2001, spurred by a drawing down of excess bank liquidity to meet the private sector's pent-up demand for bank credit, and a compression of interest rate margins stemming from increasing competition among banks (Table 4). As net sales of BOM bills declined during the first eight months of 2002, the net domestic assets (NDA) of the BOM rose sharply, and the twelve-month rate of growth of reserve money picked up to 211/2 percent as of end-August 2002. Reflecting also the operations of three new domestic banks, which were licensed in 2001, and lending by a large foreign-owned bank branch which opened in March 2002, the year-on-year rate of growth of credit to the private sector has remained above 100 percent through end-August 2002, while broad money growth rose to about 35 percent.

11. Mongolia's balance of payments recorded significant overall surpluses during 2000-01 and the first half of 2002, but its external position has nevertheless remained vulnerable. Exports rose briskly in 2000 under the impetus of rising world prices for copper and cashmere exports, but they leveled off in 2001, as the earlier improvement in the terms of trade was largely reversed, and China imposed a ban on exports of raw materials of animal origin following the outbreak of foot-and-mouth disease in Mongolia (Table 5). Import growth also rebounded in 2000 , but it was subdued during 2001 . With receipts from emigrants" remittances reported to remain buoyant, the current account deficit was kept within a range of $5 \frac{1}{2}-71 / 2$ percent of GDP in 2000-01, and gross official reserves have risen to well over $\$ 200$ million or the equivalent of about 14 weeks of imports. Notwithstanding these developments, the large real effective appreciation of the togrog that has occurred since 2000 in the face of deteriorating terms of trade has raised questions about external 
competitiveness and the sustainability of the incipient economic recovery. Further adding to these concerns, the BOM's Monetary Policy Guidelines for 2002 stipulated that the togrog should not be allowed to depreciate by more than 3 percent during the course of 2002 .

12. While the stock of Mongolia's post-1991 external debt showed signs of leveling off in 2001 and the debt service ratio has so far remained manageable (Table 6), continuing heavy reliance on foreign assistance to finance a large current account deficit makes the economy highly vulnerable to changes in donor and investor sentiment. Moreover, $a$ settlement has yet to be reached on the TR 10.5 billion stock of pre-1991 convertible ruble debt (equivalent to 10 times Mongolia's GDP), which could have significant implications for Mongolia's future debt service burden and external sustainability. While some steps were taken in 2002 to establish the principles that should guide the initial negotiations on this issue, Mongolia's tendency to accrue arrears on its much smaller post-1991 debt to Russia may complicate the settlement on its pre-1991 debt. ${ }^{6}$

13. On the structural front, while important steps have been taken to strengthen the legal framework for tax administration and budgetary management, there has been no tangible progress in the key area of public administrative reform. On the positive side, following the recommendations of recent FAD missions, legislation was adopted in the context of the 2002 budget to rationalize the assignment and intergovernmental revenue-sharing arrangements relating to the VAT, the corporate income tax, and the excise on alcohol (Table 7). ${ }^{7}$ A new Public Sector Management and Finance Law (PSMFL), which is to provide an overall legal framework to strengthen governance within the public sector, was approved in June 2002. The PSMFL could become a milestone in governance reforms in Mongolia, although it will need to be implemented with caution, especially as regards the envisaged introduction of an output-based system of resource management, which could complicate the task for expenditure control. In the area of fiscal reporting, a system for the monthly monitoring of government arrears has been established, but the compilation of fiscal accounts in accordance with GFS methodology has fallen behind schedule, although the authorities recently completed the preparation of annual estimates for 2001 . The implementation of a Treasury Single Account (TSA) was disappointingly slow through the first half of 2002, reflecting the authorities' capacity constraints, as well as political resistance to the reforms from some quarters.

14. In the areas of public enterprise reform and bank restructuring, the authorities have made notable progress, but important challenges remain. Consistent with the Fund's

\footnotetext{
${ }^{6}$ Mongolia reached an agreement with Russia for the clearance of overdue debt service payments as of end-1999, and for the payment of debt service due in 2000 and 2001, in November 2000 . However, debt service arrears reemerged at end-2001 and have yet to be settled, although a new schedule for their clearance was agreed in March 2002.

${ }^{7}$ An FAD mission evaluated the new revenue sharing arrangements in September 2002.
} 
advice during the last Article IV consultation, the Trade and Development Bank (TDB) has been privatized and is to be transferred to a consortium of foreign investors before end- 2002 . Impressive progress has also been made in the restructuring of the Agricultural Bank, which has been operated over the last two years under a donor-funded external management contract. However, the privatization of other large enterprises which are still carrying out loss-making quasi-fiscal activities has been delayed, while the energy sector's persistent financial imbalances continue to pose a threat to medium-term fiscal and external sustainability. ${ }^{8}$

15. The recent policy trends, together with the weak global environment, have douded Mongolia's medium-term prospects for sustained economic growth. In the short run, continuing robust growth in the industrial and service sectors could help raise teal GDP growth to $3 \frac{1}{2}-4$ percent in 2002 , provided that the drought-related losses in the agricultural sector can be contained. Given the considerable lags with which the incipient loosening of monetary and fiscal policies may affect domestic demand, inflation could remain within the single-digit range during 2002 . While the current account deficit is projected to widen somewhat in 2002 , its financing should be facilitated by the private capital inflows resulting from the privatization of TDB. Nevertheless, with the recovery in major export markets remaining timid, and with external competitiveness coming under threat, the medium-term outlook for exports is highly uncertain. Moreover, unless prompt steps are taken to reverse the recent trend towards easier monetary and fiscal policies, investor and donor confidence could tend to be eroded, further weakening the outlook for sustainable private sector-led investment and growth.

\section{Policy Discussions}

16. The authorities and the staff agreed that the fragility of the domestic and global environment called for redoubled efforts to protect macroeconomic stability and maintain the momentum of market-oriented structural reform in order to achieve the authorities' objectives for sustainable growth and poverty reduction. It was agreed that enduring fiscal consolidation would have to remain a centerpiece of the government's medium-term macroeconomic stabilization strategy. More specifically, rigorous pursuit of expenditure-saving reforms would be essential to enable the authorities to gradually reduce unproductive expenditures in relation to GDP, pave the way for an eventual reduction of the tax burden on the private sector, and increase the room for maneuver in the conduct of

\footnotetext{
${ }^{8}$ For a more detailed review of recent developments in public enterprise reform and privatization, see Chapter III of forthcoming Selected Issues paper.
} 
monetary and exchange rate policies. Nevertheless, there was considerable debate on the detailed aspects of fiscal, monetary and external sector polices and related reforms that would be consistent with the achievement of the above objectives.

\section{A. Fiscal Policy and Reforms}

17. The staff cautioned that the authorities' continued lax expenditure policies posed by far the greatest threat to macroeconomic stability and the government's mediumterm growth and poverty reduction goals. The slump in the earnings of the copper mining and cashmere sectors, together with declining dividends from enterprises that have been, or are about to be, privatized, suggested that overall revenue growth could no longer be counted on to restrain the overall government deficit. In these circumstances, the implementation of the government's planned increases in wages and pensions would likely exert further strong upward pressure on current outlays, which are already very high in relation to GDP. The resulting pressure on the overall government deficit would likely lead to resumed growth in the NPV of public debt in relation to GDP, which would not be sustainable, and/or would lead to costly cuts in public investment. Last but not least, the continuing recourse to heavy external borrowing to finance a large government deficit would continue to tilt the policy mix required to maintain short-term macroeconomic stability in favor of a tighter monetary policy, and could also exert upward pressure on the exchange rate, with potentially damaging effects for competitiveness, export growth, and medium-term balance of payments stability.

18. As a first step towards the restoration of fiscal sustainability, the team urged the authorities to adopt as soon as possible a realistic and transparent amended budget for 2002, which should be centered on expenditure restraint. Consistent with the objective of placing the NPV of public debt on a clearly declining path, and to partially accommodate the fall in tax receipts stemming from the decline in the world prices of copper and cashmere, the team recommended that the amended budget aim to contain the government deficit to $61 / 2$ percent of GDP. Such a target would require the adoption of measures to reduce government expenditure to no more than $42 \frac{1}{2}$ percent of GDP. To meet this objective without having to make drastic cuts in capital expenditures, the average increase in civil service wages and pensions to take effect during the last quarter of 2002 would need to be reduced to no more than 10 percent. The team also recommended that any general salary increase be limited to what would be required to compensate for the effects of expected inflation; the remainder should be differentiated on the basis of productivity, in consultation with the World Bank. Outlays on goods and services should be restrained to the extent possible, but should still be realistically budgeted to avoid any new accumulation of arrears. It would also be important to protect the government's credit-worthiness and reassure investors and donors about its future debt-servicing capacity by making adequate allocations for a continued reduction in domestic

${ }^{9}$ In the context of its Public Expenditure and Financial Management Review (PEFMR), the World Bank fielded a mission to Ulaanbaatar in September 2002 to discuss alternative options for civil service wage policies and reform strategies. 
and external arrears, especially in connection with post-1991 debts to Russia. The team emphasized the need to fully reintegrate into the amended budget the accounts of the 26 social sector entities that were excluded from the initial budget and to keep them on-budget thereafter as long as they conduct any fiscal or quasi-fiscal operations.

19. An amended budget for $\mathbf{2 0 0 2}$ was approved by an extraordinary session of Parliament on August 30, 2002. Consistent with the staff's advice, the amended budget reincorporated the accounts of the aforementioned 26 social sector entities, included more conservative revenue estimates, and aimed to restrain the overall deficit to $61 / 2$ percent of GDP. To achieve this deficit target, the projected increase in net lending for capital projects was revised downwards. However, there are doubts about the realism of the budget's other expenditure estimates. Wage and salary allocations, in particular, seem barely adequate to cover the overruns in evidence so far in 2002, and would likely fall short of what would be needed to fund the budgeted 20 percent increase from October 1 . The allocations for goods and services are lower by 1 percentage point of GDP relative to the 2001 outturn and could prove insufficient to meet budgetary entities" ordinary needs. In addition, a sharp rednction in domestic net lending, which is envisaged for the latter part of 2002, is to be funded through large net repayments of previously loaned funds, which may well fail to materialize. Finally, no allocations appear to have been made for the repayment of external arrears. In all, to meet the sustainability objective, domestically financed capital expenditures would probably have to be sharply curtailed, while existing plans for wage and pension increases would have to be deferred or suspended.

20. It was agreed that a credible public sector reform program to gradually reduce the ratio of current expenditure to GDP would have to be the centerpiece of Mongolia's fiscal consolidation strategy over the medium term, so as to eliminate pressures for further increases in taxes and/or cuts in capital expenditures down the road. In this context, the team expressed concern that the authorities' existing plans to grant further civil service wage and pension increases in 2003-04 were inconsistent with the attainment of the above objectives. The authorities maintained that their planned wage increases were necessary to ensure adequate remuneration of civil servants and would be offset by the outsourcing of social sector functions and a downsizing of the civil service (Box 4). However, the team noted that the measures proposed by the government to accommodate the wage increases appeared to be neither credible nor desirable. A downsizing of the public sector achieved through the contracting out or privatization of social services was unlikely to generate any real savings and might only lead to an increase in contingent government 


\section{Box 4. Government's Fiscal Reform Agenda and Implications for Fiscal Sustainability}

The Government of Mongolia has endorsed an ambitious fiscal reform agenda with the overriding aims of improving the pro-business orientation of the tax system while also providing for the funding of the increases in public wages and pensions envisaged in its Action Program. While the details on these measures have yet to be worked out pending their consideration by Parliament, this box describes the highlights of the reform agenda, and the staff's assessment of the implications for fiseal sustainability, based on available information.

\section{Revenue Side}

Reduction in Income tax rates. The top rate of the corporate income tax (CIT) and the personal income tax (PIT) is to be reduced from 40 percent to 30 percent from January 2003 and would be lowered further toward a unified rate in the medium term. While the loss of PIT revenue would be small, the resulting loss in CIT revenues is projected to be on the order of 0.6 percentage points of GDP.

Increase in tax exemptions. A set of tax incentives for promoting exports and investment is to take effect in 2003. As a first step, in June 2002, legislation was passed to establish a free-trade zone in Altarbulag aimag. In addition, the PIT tax credit is to be increased in two stages (estimated revenue loss of 0.1 percentage points of GDP a year in 2003-04), and VAT exemptions are to be introduced for processors of agricultural products, to offset cascading and bring the processing industries' tax liabilities more in line with actual value added.

Broadening of the tax base. To make up for the revenue losses from the above measures the authorities plan to eliminate a large number of tax exemptions, including most notably, the temporary tax relief for industries with foreign investment or substantial exports and the exemption of domestic beer from the excise tax.

\section{Expenditure Side}

Wage and pension Increases. Under the 2002 budget, public wages and pensions would rise by 20 percent from October 2002. However, according to a tripartite agreement signed by trade unions, the employer's federation, and the government in June 2002, the increase would be 25 percent in 2002 and would be followed by another increase of 30 percent in 2003, while the government's draft Medium-Term Budget Framework (MTBF) envisages an increase of 20 percent with effect from October 2003 , followed by a further inerease of 27 percent, with effect from April 1, 2004. As a result of these increases, the ratio of current expenditures to GDP would rise by $1 \frac{1 / 2}{2} 2$ percentage points of GDP in 2003 and another $3 \frac{1 / 2}{2}$ percentage points in 2004 .

Social sector privatization and civil service reform. To contain its wage bill during 2003-04, the government intends to privatize in a phased manner 90 institutions in the health and education sectors, while also introducing reforms to streamline the civil service. As a result, 16 percent of current government employees would have their civil service status revoked, and another 12 percent would be laid off.

Social security reform. Further saving would be generated by increasing the female retirement age of 55 by half a year annually, up to 60, abolishing early retirement, and expanding the coverage of the pension scheme to herders and self-employed starting in 2003. The authorities estimate that the combined annual savings generated through these measures would amount to 0.5 percentage points of GDP in 2003.

In the stafrs view, the government's wage and pension policies and reform agenda would pose a serious threat to fiscal sustainability. On the revenue side, the uncertain benefits from the broadening of the tax base would be unlikely to make up for the losses resulting from the reduction in tax rates. In addition, while most of the new tax exemptions aim at newly established enterprises, the tax base could be significantly eroded over time owing to abuse and increased administrative costs. On the expenditure side, layoffs of the suggested magnitude would be difficult to implement in a timely manner in the light of other countries' experiences, and the planned social sector privatization would either undermine service delivery or would be unlikely to yield any true budgetary savings. While some of the envisaged pension reform measures could generate welcome savings in the long run, their impact on the budget would likely be negligible over the medium term. 
liabilities which would undermine fiscal transparency. Moreover, existing proposals for largescale civil service layoffs did not seem realistic, nor did the government's plans for across-theboard wage increases appear justifiable on the basis of economic considerations. ${ }^{10}$

21. To minimize the threat to macroeconomic stability, lessen any adverse impact on service delivery, and enhance the pro-growth orientation of fiscal policy, the team urged the authorities to suspend their existing plans for civil service wage and pension increases for $2003-04$. The authorities were also encouraged to postpone any decisions on their future wage and pension policies until they have had a chance to reconsider their options for civil service and pension reforms in a systematic and realistic manner, in consultation with the World Bank. The government's final wage policy decisions would need to be clearly justified, articulated and costed in the final version of the MTBF, which is now expected to be submitted to Parliament in May 2003. The authorities indicated a willingness to review these matters in collaboration with the World Bank's PEMFR team, which was tentatively scheduled to return to Ulaanbaatar for follow-up discussions on civil service reform issues in November 2002.

\section{The authorities and the staff agreed that the high burden of taxation on the} private sector was a drag on investment and growth, which needed to be reduced over the medium term. Nevertheless, given the risks on the expenditure side, the team cautioned against the planned introduction of any new tax cuts and incentives under the 2003 budget. The authorities' preliminary plan was to reduce income tax rates and introduce new tax incentives to promote exports and the processing of agricultural products, while taking some steps to broaden the tax base. While the government believed that this tax reform agenda would be revenue-neutral, the team questioned the reliability of the estimated short-run benefits from the broadening of the tax base. Instead, the team considered it appropriate to aim to stabilize the revenue-to-GDP ratio over the medium term, with a progressive expansion of the tax base making room for a gradual reduction of tax rates. However, pending the approval of a sound and credible wage and pension policy, the team recommended that the government postpone any reduction in tax rates, abstain from the

\footnotetext{
${ }^{10}$ While the average monthly wage of civil servants was equivalent to about US\$50 during 2001 , which was $10-20$ percent below the average wage level in the private sector, wage data are likely to understate the total compensation of civil servants. In addition, civil service wage increases in recent years-including those implemented in October 2002-have been skewed in favor of lower-level staff. Thus, while unskilled civil servants' wages have probably caught up with those of their private sector counterparts, the salaries of managerial staff have lagged. Given the overriding need to protect fiscal sustainability, the challenge for the government will be to restrain its overall wage bill, while also taking steps to decompress its wage structure, attract quality civil servants, and shed unproductive employees.
} 
granting of new tax holidays, and suspend plans to establish free trade zones. While the legislation to establish Mongolia's first free trade zone has since been approved by Parliament, the authorities indicated a willingness to withdraw their other tax proposals.

23. The team urged the authorities to step up their efforts to improve fiscal transparency in the period ahead in line with the recommendations of the fiscal ROSC. The authorities explained that the compilation of semi-annual general government accounts in accordance with GFS methodology had been delayed, largely because of technical constraints and questions about the division of responsibilities within the MOFE. Following the recent presentation of the fiscal accounts for 2001, significant progress was being made towards producing data for general government operations for the first half of 2002 . Given the discontinuities in the budgetary data resulting from the exclusion of 26 social sector entities from the 2002 budget, the team emphasized the importance of producing properly consolidated semi-annual accounts for the full general govermment as a matter of priority.

24. After substantial delays in its pilot phase, the authorities decided to expand the TSA program on an accelerated basis, following participation in an IMF-sponsored conference on treasury reform in Kazakhstan. Although the staff team cautioned that it might be more prudent to first complete and assess the pilot phase, the government began a country-wide roll-out of the TSA arrangement in July 2002, including by establishing local treasury offices in all provinces, closing most budget entities' bank accounts outside the TSA arrangement, and beginning to process payments exclusively through treasury ledger accounts. To minimize political resistance at the early stages of reform, the social insurance authority (SIA) and the Mongolian National University (MNU), which had been included in the TSA pilot, as well as nonpilot budget entities with considerable own revenues, have been excluded from the TSA for the time being. To address technical difficulties in remote locations in which there is no BOM branch, each local budgetary office would maintain a separate TSA at a commercial bank of its choice, provided that the selected bank meets a specified set of prudential standards. The staff urged the authorities to implement the rephased TSA program with determination. A key pending issue was the future treatment of the SIA. Another difficulty related to the TSA bank accounts for the Ulaanbaatar City municipality. These accounts should, in principle, be maintained at the BOM, but are temporarily maintained with Ulaanbaatar City Bank, which has long-established economic and political links with the Ulaanbaatar City government.

\section{B. Monetary Policy and Banking System Reforms}

25. While monetary and credit developments may have been influenced by an upward shift in money demand in the face of the ongoing rehabilitation of Mongolia's banking system, it was agreed that monetary growth needed to be moderated over the medium term to achieve the government's disinflation and external reserve objectives. In the authorities' view, the rapid expansion of bank lending to the private sector that 
occurred in 2001 should not be a cause for concern as their efforts to improve the legal environment to facilitate loan recovery had made the banking system more resilient and better able to manage credit risks. Nevertheless, following the continuing rapid growth of money and credit during the first half of 2002 , the authorities recognized the need to guard against an overly rapid expansion of bank liquidity and undertook to contain reserve money growth to well below 20 percent over the full year. Accordingly, beginning in July 2002 , the BOM took steps to raise the rates and placement of BOM bills. However, the staff cautioned that the authorities would need to take much stronger action in the period ahead if they are to adhere to their monetary targets, especially if there is a continuing increase in net bank credit to government.

26. The discussions recognized that a continuing increase in the BOM's NIR could necessitate large-scale sterilization operations in order to contain reserve money growth within a prudent range. In these circumstances, it was agreed that other monetary policy instruments needed to play a supportive role in the short run to ensure that the issuance of BOM bills does not place an undue burden on the BOM's profit and loss accounts. The BOM agreed that it would need to monitor closely its on-lending undertaken with concessional external assistance and avoid injecting funds into the banking system through the use of other instruments. To ease concerns about the possible implications of the 2002 Monetary Policy Guidelines, which stipulated that the BOM would offer new rediscounting facilities and preferential credit schemes for selected enterprises, the BOM issued a circular to commercial banks in June indicating that it would not engage in any such operations during 2002. Over the medium term, with fiscal consolidation and the orderly servicing of public debt gradually enhancing the government's creditworthiness, the BOM could begin to convert its holdings of government debt into marketable securities and substitute these or other government debt instruments for BOM bills in monetary management operations.

27. The mission emphasized that the development of a sound and efficient banking system was essential to prevent a reemergence of new contingent liabilities for the budget over the medium term and would be key to promoting the private sector as the main engine of economic growth. In this context, the team welcomed the introduction of legislation which had facilitated bank seizures of collateral on nonperforming loans. The rehabilitation of the Agricultural Bank, together with the privatization of the TDB and the commencement of operations in Mongolia by a number of foreign-based credit institutions, all pointed to significant improvements in bank competition and efficiency. However, some preliminary indications suggested that rapid credit growth in the face of a compression of bank profit margins was beginning to lead to a decline in some institutions' loan quality and a reduction in the banking system's aggregate risk-based capital adequacy ratio, while the widespread bank practice of repetitive roll-over of loans tended to understate the level of nonperforming loans. The authorities were urged to take steps to tighten enforcement of loan classification and provisioning standards in line with recent MAE mission recommendations. In the case of problem banks, the team stressed that decisive actions should be taken to 
ensure compliance with existing memoranda of understanding (MOUs) and, if needed, the MOUs should be amended to foster the build-up of liquidity required to fund expected deposit outflows following TSA implementation. The team was informed that the BOM had recently issued new anti-money laundering recommendations to banks in line with Financial Action Task Force (FATF) guidelines, although new legislation would need to be enacted to require banks to file reports on suspicious accounts and empower the authorities to freeze such accounts.

\section{External Sector Policies}

28. The authorities and the staff agreed that exchange rate flexibility needed to be enhanced in the period ahead to support Mongolia's strategy of export-led investment and growth. It was noted that the sustained inflows of foreign assistance, including in connection with the budget, together with the recent pickup in emigrants' remittances, had probably been among the factors underlying the recent strength of Mongolia's balance of payments (Box 5). In this context, the BOM's intervention practices, together with the system used every week to set its official exchange rate, had resulted in the maintenance of a virtually stable nominal exchange rate vis-à-vis the U.S. dollar between late 2000 and mid-2002. In the team's view, the consequent real effective appreciation of the togrog in the face of a weakening of export growth and a worsening of the global environment was a potential cause for concern. The authorities believed that the recent developments basically reflected market forces, which had enabled the BOM to maintain exchange rate stability while accumulating reserves and comfortably meeting its NIR targets. However, the team observed that, to the extent that some of the continuing large capital inflows, including in connection with the privatization of TDB, cannot be sustained over the medium term, an upward adjustment in the BOM's NIR target might be warranted in the short run.

29. It was agreed that policy vigilance would be required to guard against an excessive erosion of external competitiveness, especially in light of China's recent accession to the WTO, which could place Mongolia's manufacturing exports under new competitive pressures. To improve the responsiveness of the exchange rate to market forces, the BOM took steps to widen the buy-sell margin around its mid-point market intervention rate beginning in July 2002 and agreed to consider adjusting the mid-point rate on a daily rather than weekly basis in the period ahead to allow for greater exchange rate flexibility. To address concerns regarding the exchange rate clause of the Monetary Policy Guidelines for 2002, the BOM undertook an exchange of letters with the Chairman of the Parliament's Economic Standing Committee, which clarified that that clause will not bind BOM policies during the rest of 2002 .

30. It was also agreed that Mongolia's continued heavy reliance on deht inflows to cover its current account deficit, together with its vulnerability to terms of trade and climatic shocks, might constrain the country's future debt servicing capacity. Against this background, external debt management policies would have to remain prudent and the authorities should not provide new public guarantees on private-sector external borrowings 


\section{Box 5. External Performance and Short-Run Prospects in an Uncertain Global Environment}

The recent slowdown of the world economy has led to unusually large uncertainties and downside risks for both developed and emerging economies. The downside risks reflect the possibility of a prolonged or double-dip slowdown in activity in major industrial countries, coupled with an apparent increase in risk aversion among investors, which could put a damper on both commodity trade and international capital flows, thus discouraging investment and growth in capital importing countries.

Mongolia's export performance is vulnerable to changes in global demand conditions and terms of trade losses, but it has so far enjoyed some measure of protection from the recent slowdown, owing in part to the geographical pattern of its trade. Its main exports include copper, gold, processed and unprocessed cashmere products, hides and skins, meat, and other animal products. The outlook for exports of copper has worsened markedly in the last year, as the slowdown in high-technology industries depressed international copper prices. Moreover, demand for finished cashmere products in major industrial countries, especially the U.S. and Japan, has slowed. However, the impact of these developments on Mongolia's export earnings has been moderated, so far, by a rise in gold prices, increased gold production from newly developed mines, and compensating increases in the volume of exports of copper and raw cashmere. The vulnerability of Mongolia's export perfonmance may have been limited so far by continued strong economic growth in Russia and China, which are Mongolia's largest trading partners. Russia absorbs most of the meat exports from Mongolia; although Mongolia's major exports to China are globally traded commodities (copper, other metals, and raw and partially processed cashmere), which may be ultimately destined for export to industrial countries, the demand for these products is also influenced by China's domestic demand, which has so far been robust.

The short-term impact of a worsening external environment on Mongolia's current acconut has also been moderated by the sustained growth in receipts from emigrants' remittances. While not all of these inflows are recorded in official balance of payments statistics, there is considerable anecdotal evidence suggesting that receipts from emigrants to Korea alone have become a steady source of foreign exchange and are among the factors accounting for the recent strength of the togrog. In all, the net effect of a weakening global outlook on Mongolia's current account should be modest during 2002. The staff's baseline scenario now projects a current account deficit during 2002 that exceeds the projection in the last staff report (EBS/01/166) by US\$15 million or 1.2 percent of GDP.

Mongolia's limited reliance on private capital makes it less exposed to the risks stemming from a possible drying op of commercial loans. While foreign direct investment (FDI) is likely to decline in response to the worsening prospects for the copper and cashmere industries, the inflows associated with the recent privatization of TDB alone are projected to be on the order of at least US\$12 million (1 percent of GDP) in 2002 and another US $\$ 28$ million ( 2.2 percent of GDP) during 2003-04. While a major tisk is that the decline in new FDI inflows may be exacerbated by a reduction in official loan disbursements if the government does not take timely action to bring its reform program back on track, this is a risk that is unrelated to the global enviromment.

The upshot of this analysis is that, if domestic policies are brought into line with staff recommendations, the effect of the worsening global environment on Mongolia's external finances should be manageable in the short run. A modest widening of the current account deficit could be readily covered by the significant inflows of concessional financing and private capital, which are already in the pipeline. In the event that a larger than expected widening of the current account deficit threatens the achievement of the BOM's reserve objectives, a market-driven depreciation of the exchange rate could serve to restore balance of payments equilibrium without adversely affecting investment and medium-term growth prospects. 
nor contract any new nonconcessional external debts. The authorities were also intent on maintaining orderly relations with all creditors and had reached agreement on a schedule for the settlement of arrears on post-1991 debt to Russia. In addition, they noted their readiness to reach early agreement with Russia on the large stock of pre-1991 transferable ruble debt. Steps were also under way to resolve other outstanding claims by foreign creditors on the order of US $\$ 30-40$ million, which had arisen from the past issuance of guarantees on nonconcessional external loans to public and private enterprises.

31. The authorities recognized that a liberal trade and investment system would have to remain a linchpin of Mongolia's export-oriented growth strategy. While Mongolia's formal trade regime is among the least restrictive in Asia, inconsistent application of customs regulations and a lengthy customs clearance process, together with an excessive number of required licenses, inspections, and certificates may still discourage trade and foreign direct investment. ${ }^{11}$ The team urged the authorities to simplify customs controis, licensing, and regulations, especially in connection with quality certification for the import and export of raw materials and minerals. Equally important, steps should be taken to ensure that laws and regulations are enforced in a transparent and nondiscriminatory fashion by the national courts and regulatory authorities. Given the large investment requirements for the rehabilitation and upgrading of essential infrastructure, a special effort may be required to increase private participation in infrastructure projects. The authorities noted that they had recently established a one-stop agency for foreign investors, and were taking steps to remove laws or regulations that protected the BOM's dominant role in the marketing of gold exports.

\section{MEDIUM-TERM OUTLOOK AND DEBT SUSTAINABILITY ANALYSIS}

32. Mongolia's debt-to-GDP ratio is very high, even with the assumption that the pre-1991 transferable ruble debt to Russia can be rescheduled on terms that are relatively favorable. In this context, it is difficult to identify the conditions that would ensure medium-term fiscal and external sustainability with any degree of certainty. For illustrative purposes, the staff has made a preliminary attempt to estimate the potential impact of alternative terms of settlement of the transferable ruble debt (Annex III). The results indicate that, even with an up-front discount rate of 90 percent, both the stocks of Mongolia's public debt and external debt would exceed 180 percent of GDP by end-2002, while the ratio of public debt to general government revenue would exceed 500 percent of GDP and the ratio of external debt to exports of goods and services would be higher than 250 percent (see Table below). To ensure fiscal and external sustainability in these circumstances, in conjunction

\footnotetext{
${ }^{11}$ For a summary of Mongolia's trade regime, see Annex of the forthcoming paper on Selected Issues and Statistical Appendix.
} 
with the policies recommended above, Mongolia might need to secure better terms for the restructuring of its debt to Russia and/or approach the Paris Club to request a formal rescheduling on the whole stock of its official debt.

\begin{tabular}{|c|c|c|c|c|c|c|}
\hline \multicolumn{7}{|c|}{$\begin{array}{l}\text { Mongolia: Summary Indicators of Fiscal and Extemal Sustainability } \\
\text { (In percent) }\end{array}$} \\
\hline & \multicolumn{6}{|c|}{ Frojections } \\
\hline & 2002 & 2003 & 2004 & 2005 & 2006 & 2007 \\
\hline \multicolumn{7}{|l|}{ I. Baseline Scenarlo If } \\
\hline \multicolumn{7}{|l|}{ A. Excluding pre-1991 transferable ruble debt to Russia } \\
\hline Phublic debt/General government revenues & 248.2 & $24 \mathbf{5 . 4}$ & 243.3 & 236.5 & 227.7 & 218.4 \\
\hline Public debu/GDP & 88.8 & 87.9 & 87.0 & 84.6 & 81.4 & 78.1 \\
\hline Extemal debuExports of goods and services & 127.9 & 127.6 & 127.5 & 123,9 & 121.7 & 119,4 \\
\hline Extemal debt/GDP & 87.0 & 87.7 & 87.0 & 84.6 & 8].3 & 77.7 \\
\hline Public Debt Service/General government revenues & 16.0 & 10.6 & 8.3 & 6.8 & 6.4 & 6.5 \\
\hline Extemal Debt Service/Expotts of goods and services & 4.7 & 4.2 & 4.1 & 4.1 & 4.0 & 4.0 \\
\hline \multicolumn{7}{|l|}{$\begin{array}{l}\text { B. Incluêing pre-1991 transferable ruble debt to Russia, with settlement } \\
\text { at end-1002 at } 90 \text { percent dlscount }\end{array}$} \\
\hline Public debt'Gencral government revenues & 514.2 & 489.7 & 468.0 & 442.9 & 416.9 & 380.2 \\
\hline Public deb/GDP & 184.1 & 175.9 & 167.9 & 158.9 & 149.6 & 136.4 \\
\hline External deht/Exports of goods and services & 268.0 & 255.7 & 246.0 & 232.8 & 223.7 & 209.1 \\
\hline Extemal deht/GDP & 182.2 & 175.8 & 167.9 & 158.9 & 149.5 & 135,0 \\
\hline Public Debt Serwice/General goventment tevenues & 15.0 & 24.8 & 21.4 & 18.8 & 17.5 & 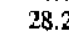 \\
\hline Extermal Debt ServicerExports of goods and services & 4.7 & 11.7 & 11.0 & 10.5 & 9.9 & 16.0 \\
\hline II. Sensituvity analysis (excluding pre-1991 transferable ruble debt to Russia) & \multicolumn{6}{|c|}{$\begin{array}{l}\text { A. Public debt-to-GDP ratio } \\
\text { 1. Interest rate, real GDP growih rate, primary balance and non-debt flows }\end{array}$} \\
\hline (in petcent of GDP) are at average levels of past sewen years & 92.6 & 96,0 & 100.2 & 102,9 & 105.0 & 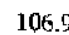 \\
\hline 2. Real GDP growth shock in 2002 and 2003 (two standard deviations) & 92.5 & 96.0 & 94.4 & 91.3 & 87.6 & 83.7 \\
\hline 3. Primary balance shock in 2002 and 2003 (two standard deviations) & 97.6 & 104.8 & 102.4 & 98.6 & 94.2 & 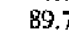 \\
\hline \multicolumn{7}{|l|}{ B. Extemal debt-to-GDP ratio } \\
\hline $\begin{array}{l}\text { 1. Interest rate, real GDP growth rale, US\$ GDP deflator growth. non-interest } \\
\text { current account, and non-debt flaws (in percent of GDP) are at average levels } \\
\text { of past seven years. }\end{array}$ & 85.0 & 84.6 & 84.2 & 83.0 & 80.8 & 77.5 \\
\hline $\begin{array}{l}\text { 2. Combined stocks on interest rate, real GDP gouwth rate, US\$ GDP deflator } \\
\text { growth, non-interest current account, and non-debt flows in } 2002 \text { and } 2003 \\
\text { (one standari deviation). }\end{array}$ & 96.4 & 103.4 & 101.6 & 98.2 & 93.9 & 89.4 \\
\hline 3. One-time 30 percent depreciation sbock in 2002 & 124.1 & 122.4 & 119.3 & 114.6 & 09.2 & 103.6 \\
\hline
\end{tabular}

33. Pending a settlement on the above issues, the staff has developed a framework to assess Mongolia's fiscal and external debt dynamics under a number of alternative scenarios. The baseline scenario suggests that, if the authorities adopt reforms to progressively lower the ratio of current government expenditure to GDP as needed to reduce the overall budget deficit to 4-41/2 percent of GDP by 2006-07, the external current account deficit (including official transfers) would be manageable, and the stocks of both external debt and public debt would peak in 2002-03 and decline steadily thereafter (Table 8). However, the levels of extemal and public debt would remain high, with post-1991 debt amounting to 80 percent of GDP by 2006 and total debt, including the pre-1991 transferable debt to Russia on the assumption that it is settled in 2002 at a 90 percent discount, amounting to 150 percent of GDP. These results underscore the vulnerability of Mongolia's fiscal and external positions and reinforce the need for steadfast adherence to a sound medium-term policy framework along the lines discussed in the preceding sections. 
34. Abstracting from the potential new bardens on the budget and the balance of payments that may result from a settlement on the pre-1991 debt to Russia, the baseline scenario shows considerable resilience to external shocks, although a number of risks need to be highlighted. As illustrated in Annex III, which details the results of a number of stress tests, the pursuit of policies along the lines envisaged in the baseline scenario should help to improve Mongolia's debt dynamics over the medium term even if the economy is subject to a variety of external shocks. Indeed, the biggest risk would be faced in the case of policy slippages, especially in the fiscal area. Thus, a widening of the government's primary deficit towards the average level observed over the last few years, together with a worsening outlook for growth, could lead to continuing increases in Mongolia's post-1991 public debt, which would rise to more than 105 percent of GDP by 2006-07. Beyond this, the results also highlight Mongolia's exposure to the risks associated with a large depreciation of the exchange rate and/or a real GDP shock. Mongolia has experienced both types of shocks in the recent past, and its continuing vulnerability to the effects of potentially volatile terms of trade and climatic conditions reinforces the need for prodent fiscal and external debt management policies and a flexible exchange rate policy.

\section{OTHER ISSUES}

35. The discussions followed up on the recommendations of recent Fund technical assistance on economic and financial statistics (Box 6 and Annex IV). To remove the uncertainties relating to recent national accounts data, the authorities were urged to finalize their decision relating to the appropriate treatment of extraordinary weather-related losses to the herd stock as soon as possible and implement it in a transparent manner. In the fiscal area, the authorities would need to take decisive steps to ensure the timely compilation and reporting of semi-annual fiscal data in accordance with GFS methodology, as noted earlier.

36. The recently completed on-site safeguards assessment of the BOM identified several vulnerabilities, particularly in the areas of its financial reporting framework and system of internal controls (Annex V). In accordance with staff recommendations, the BOM at the end of 2001 unwound its credit guarantees to domestic gold mining companies provided under its deposit and trading agreement with a foreign metals trading company. Consistent with the safeguards assessment's recommendations, the BOM had recently published its audited financial statements for 2000 and 2001, obtained an independent appraisal to support the fair value of its property, and enhanced its monthly reconciliation procedures for data on NIR. The BOM was also taking steps to fully adopt International Accounting Standards (IAS), so as to provide a transparent accounting for its gold and foreign exchange option and derivative transactions in its financial statements. In the meantime, the BOM agreed to provide the staff with monthly data on its off-balance sheet transactions along with NIR data. The $\mathrm{BOM}$ is also considering ways to amend the central bank law to provide independent oversight of its operations.

37. The government circulated its first draft of a full PRSP to the donors attending the Mongolia Consultative Group meeting held in Ulaanbaatar in July 2002. The staff's preliminary view is that, while progress has been made towards broadening participation in 


\section{Box 6. Status of Implementation of Measures to Strengthen Statistical Data}

A Data ROSC mission, which visited Mongolia in May 2000, prepared an assessment of data dissemination practices in Mongolia against the GDDS, and the data module of the ROSC was posted on the Fund's external web site in May 2001. The ROSC mission found that the data produced generally met, and in many instances exceeded, the recommendations of the GDDS with respect to periodicity and timeliness of dissemination. However, further improvements were recommended with respect to data quality and policy value. Specific recommendations for improvements in fiscal data quality were subsequently provided by a joint FAD/STA mission in March 2001, which also initiated the preparation of a fiscal ROSC; the status of implementation of these recommendations has been covered in the discussion on fiscal policies above. The steps that have been taken to follow up on some of STA's other recommendations are summarized below.

\begin{tabular}{|c|c|}
\hline Areas for Further Development & Status \\
\hline $\begin{array}{l}\text { Real Sector } \\
\text { The national accounts are weak in coverage of the } \\
\text { informal sector and small-scale activity, and the } \\
\text { methodology for dealing with catastrophic losses in } \\
\text { the animal husbandry sector remains under question. } \\
\text { - Labor market statistics need to be developed } \\
\text { through the establishment of quarterly sample } \\
\text { surveys. } \\
\text { The methodology for the derivation of the GDP } \\
\text { deflator is questionable. } \\
\text { There is no Producer Price Index (PPI). } \\
\text { There is no national Consumer Price Index (CPI). } \\
\text { The capital city CPI is used as the national CPI. } \\
\text { GDP data on the expenditure side are not available } \\
\text { - }\end{array}$ & $\begin{array}{l}\text { A working group has been set up to assess the } \\
\text { options for the treatment of catastrophic losses, but } \\
\text { the decision on this issue has been delayed, owing to } \\
\text { the political sensitivity attached to GDP data. } \\
\text { - Preparatory work for a Labor Force Survey was } \\
\text { conducted in } 2002 \text { under joint NSO-ADB project, } \\
\text { but follow-up steps have not yet been taken. } \\
\text { The NSO plans to introduce a double-deflation } \\
\text { method for } 2002-04 \text {. } \\
\text { The industrial sector has started using the Central } \\
\text { Product Classification codes with a view to } \\
\text { developing them as a base of PPI. } \\
\text { Data collection is under way to develop a national } \\
\text { CPI. }\end{array}$ \\
\hline
\end{tabular}

- Raw data need to be refined with a view to producing reliable quarterty estimates of GDP.

Fiscal Sector

- Actual annual data that are publicly disseminated are limited to general government operations.

- The classification detail is insufficient. No data on the overall balance and its financing are disseminated.

- Only a total figure on central government debt is published without disaggregation.

- Some detailed information on the central and local government has been made available in annual and monthly publications.

- Monthly reports now cover the overall balance, and the authorities are considering electronic publication on monthly fiscal data including financing data.

\section{Financial Sector}

- The range of interest rates needed for policy evaluation is not published.

\section{External Sector}

- Data on merchandise trade are subject to significant end-of-year revisions by the General Customs Administration, which raise questions about the accuracy and reliability of monthly and quarterly data.

- Private sector transactions related to services, emigrants' remittances, foreign direct portfolio investments, and short-term capital flows are inadequately covered and there are significant gaps in the measurement of private sector external debt.

- An internetional investment position statement is not produced.
- The BOM is ready to disseminate data on interest rates on government bonds.

- The Customs Administration has begun to implement a system of verification of trade data through comparison of Mongolian data with data of major partner countries.

- The BOM has introduced an enterprise survey to improve the measurement of foreign direct investment. A draft Law on Foreign Exchange Regulation has been prepared to set the legal obligations for residents to provide the BOM with the necessary information to compile the balance of payments statistics. 
the consultative process and enhancing national ownership, significant gaps will need to be filled in the macroeconomic framework, the policy matrix, and poverty indicators before the PRSP is ready to be considered by the Fund and Bank Boards.

\section{V1. STAFF APPRAISAL}

38. Mongolia has made progress towards stabilizing and reforming its economy in recent years, but it continues to face important challenges. Since the conclusion of the last Article IV consultation in January 2000 , the overall balance of payments has recorded significant surpluses, external reserves have been built up to more comfortable levels, and inflation has been reduced to the single-digit range. On the structural front, the banking system has continued to be restructured and rehabilitated, privatization is in the process of being revived, and steps are being taken to improve fiscal transparency and accountability. However, economic growth was depressed in $2000-01$ by the extraordinarily large weather-related losses in the animal husbandry sector, and progress towards reducing poverty has been disappointingly slow. Moreover, the outlook for growth and poverty reduction in the period ahead is clouded by uncertainties regarding the government's commitment to the pursuit of sound macroeconomic policies and market-oriented reforms.

39. The biggest policy challenges are in the fiscal area. Decisive action to arrest, and begin to reverse, the recent years' sharp increase in the ratio of public expenditure to GDP will be essential to reduce the budget deficit to a sustainable level, eliminate government arrears, and place Mongolia's large public debt burden on a clearly declining path. The consequent reduction in the government's borrowing requirement should go a long way towards easing the burden of adjustment on monetary and exchange rate policies, increasing business confidence, and eliciting contimued donor support. A sustainable fiscal position would also be key to protecting the funding of essential public investment, the provision of basic health and education services, and social safety nets, as needed to meet the government's poverty reduction objectives. But the achievement of these objectives is now seriously threatened by the prospect of excessive, and economically unjustifiable, increases in civil service wages and pensions, coupled with an erosion in the government's revenue base. The government's existing plans to generate offsetting savings through drastic cuts in the size of the civil service lack credibility, and it is doubtful whether such cuts could be implemented without endangering the delivery of essential public services. Moreover, the granting of large general wage increases prior to the launching of civil service reform would tend to increase the costs of the reform, and decrease its perceived fiscal benefits, thereby diminishing its political viability and likelihood of implementation.

40. While the recent approval of an amended budget for $\mathbf{2 0 0 2}$ entails welcome steps towards the reintegration of all budgetary entities into the government's accounts, it falls short of what would be required to prevent a reversal of the recent progress towards fiscal consolidation. Although the budget's revised revenue estimates have been scaled down to more realistic levels, allocations for key categories of spending appear to be inadequate. To prevent any significant overshooting of the amended budget's overall deficit 
target without excessively compressing domestically financed capital expenditure, the authorities are urged to defer or suspend the implementation of the budgeted wage and pension increases during the last quarter of 2002.

41. Orer the medium term, fiscal policy will need to continue to be geared primarily to protecting macroeconomic stability, while also aiming to improve public sector efficiency. To these ends, the authorities are urged to suspend their existing plans for further wage and pension increases for 2003-04. To reassure investors and donors that political considerations will not shake the government's commitment to fiscal sustainability, the government's final decisions on wage and pension policies for 2003-04, together with the accompanying expenditure-saving reforms, should be clearly articulated, justified, and costed in a realistic MTBF, which should be considered by Parliament as soon as possible. The government, in collaboration with the World Bank, is also urged to develop and adopt a longerrun reforn program to establish a more productive and merit-based civil service while taking steps to protect access to basic health and education services.

42. To ensure that scarce public resonrces are put to the best use, continued efforts should be made to improve fiscal transparency and accountability. In the area of fiscal data monitoring and reporting, the preparation of timely semi-annual consolidated fiscal accounts in accordance with GFS methodology should be undertaken as a matter of priority. To protect the integrity of fiscal data, the budget for 2003 and future years, and the monthly monitoring systems for revenues, expenditure and arrears, should continue to cover the entire general government sector as defined under the 2001 budget. The staff welcomes the recent progress in the implementation of the government's rephased treasury reform program. To restore the program's credibility, the authorities need to adhere strictly to their revised timetable for the key measures, including through the timely extension of the TSA to the social security system. These efforts would warTant continued FAD technical assistance.

\section{While the last year's extraordinary expansion of credit to the private sector is} partly due to a welcome return of public confidence in the banking system, great vigilance will be needed to prevent macroeconomic difficulties and credit quality problems down the road. The recent effort to increase the placement and yields of BOM bills has been an important step in this direction. The authorities are encouraged to take additional action in the period ahead to protect the achievement of the BOM's revised monetary program targets for the remainder of 2002. In addition, any new on-lending programs undertaken with concessional external assistance should be carefully screened and paced, and the BOM should abstain from offering any new rediscounting facilities or guarantees for nonconcessional Ioans. In the area of bank supervision, the BOM is urged to tighten the enforcement of prudential standards, including by gathering information on early-warning indicators of loan impairment and by instructing banks to apply stricter loan appraisal and classification and provisioning criteria, especially for loans rolled over more than once. In order to improve the transparency of its own operations and financial statements, the BOM should fully adopt and implement IAS as soon as possible as recommended by the on-site safeguards assessment. 
44. The flexibility of exchange rate policy needs to be enhanced in the period ahead. Relatively large and persistent inflows of official and private capital, coupled with the BOM's intervention practices, may have exerted undue upward pressure on the real effective exchange rate in recent years, and steps need to be taken to guard against an excessive erosion of competitiveness. To that end, pending the reduction of the foreign-financed portion of the government deficit to a sustainable level, the BOM may need to consider adopting a more ambitious short-term target for its NIR. To enhance the responsiveness of the exchange rate to market forces, the BOM is also urged to adjust its mid-point rate on a daily basis.

45. Mongolia's large public debt and its dependence on foreign aid to cover a large current account deficit make it highly susceptible to shifts in donor and investor sentiment. To maintain donor confidence and attract FDI inflows, the authorities will need to complement sound macroeconomic policies with prudent external debt management and market-friendly reforms, including by attaching the highest priority to the maintenance of orderly relations with all creditors and instituting a level playing field for all investors.

46. The privatization of TDB marks an important milestone in Mongolia's ongoing program to establish a more competitive and efficient banking system. The progress towards the privatization of the Agricultural Bank has also been laudable. Building on these achievements, the authorities are now encouraged to address with new urgency the economic and financial problems of other large state-owned enterprises, including in the strategically important energy sector, with a view to their early privatization.

47. Mongolia has made significant progress towards developing its statistical base in recent years, but continued efforts are required to improve data quality and reliability. The authorities, with the assistance of the resident advisor on real sector statistics, should adopt without delay a consistent and transparent methodology for the treatment of extraordinary losses in the animal husbandry sector and, on that basis, finalize and publish GDP data for 2000 and 2001 . The staff also encourages the authorities to take steps to address remaining weaknesses in the areas of real sector, fiscal, and balance of payments data in line with the recommendations of STA and FAD technical assistance.

48. It is recommended that the next Article IV consultation with Mongolia be held on the 24-month cycle that is applicable for program countries, subject to the provisions of the decision on consultation cycles approved on July 15, 2002. 
Table 1. Mongolia: Selected Economic and Financial Indicators, 1998-2002

Namirel GDP (2001): \$1030 million

Poptiation (2001) 2.37 million

Quota: SOR 51.1 milition

\begin{tabular}{|c|c|c|c|c|c|c|c|}
\hline & \multirow[t]{2}{*}{1998} & \multirow[t]{2}{*}{1999} & \multirow{2}{*}{ Est. } & \multicolumn{2}{|c|}{2001} & \multicolumn{2}{|c|}{2002} \\
\hline & & & & Prog. & Est & $\begin{array}{c}\text { Prog. } \\
\text { mositoj/165 } \\
\end{array}$ & Proj. $:$ \\
\hline & \multicolumn{7}{|c|}{ (Peroent ohange) } \\
\hline Real GDP & 3.5 & 3.2 & 1.1 & 1.4 & l.j & 4.0 & 3.9 \\
\hline 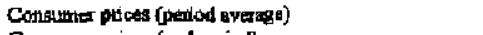 & 9.4 & 7.6 & 11.6 & 8.8 & 8.0 & 6,0 & 5.0 \\
\hline \multirow[t]{2}{*}{ Consumer pmices (end pariod) } & 5.0 & 10.0 & 8.1 & 8.0 & 8.0 & 6.0 & 60 \\
\hline & \multicolumn{7}{|c|}{ (tri pureent of GDP) } \\
\hline General goversmerd reveraue & 27.6 & 272 & 33.6 & 33.6 & 38.0 & 32.7 & 35.8 \\
\hline Genaral governmente expenditure & 41.9 & 39.4 & 40.5 & 41.0 & 43.3 & 39.8 & 42.4 \\
\hline Curtent bulines & -0.7 & -22 & 3.1 & 2.7 & 4.7 & 3.1 & 2.1 \\
\hline Overall belonot & -14.3 & -122 & -6.8 & -7.3 & 5.3 & .21 & -6.6 \\
\hline Net dorneatic credit to governanat & 4.1 & 0.0 & -0.7 & .1 .5 & -1.9 & .23 & -1.9 \\
\hline \multirow{3}{*}{$\begin{array}{l}\text { Total poblic debt } 2 / 3 \\
\text { NPV of total pubtic debt }\end{array}$} & 86.0 & 100.1 & 94.7 & 94.9 & 87.6 & 56.7 & 86.8 \\
\hline & $\cdots$ & 71.8 & 64.3 & 63.1 & 60.2 & 62.4 & 58.9 \\
\hline & \multicolumn{7}{|c|}{ (Pencent chenge) } \\
\hline Net forgegrn assets & .31 .6 & 96.9 & 39.6 & 13.0 & 8.5 & 16.8 & 18.0 \\
\hline Net domestic assets & 36.5 & -23.6 & -17.9 & 23,4 & $\$ .1$ & -7.6 & 24.2 \\
\hline Dornestic erteit & 60.1 & -11.1 & 8.0 & 0.8 & 41.6 & -4.4 & 18.4 \\
\hline Crethit to anteppises & 18.5 & $\$ \$$ & 20.5 & 383 & 141.9 & 33.9 & 40.5 \\
\hline Broed money & 8. & 31.7 & 17.5 & 13.3 & 28.0 & 15.1 & 20.1 \\
\hline Reserve moniey & 13.5 & 31.8 & 19.4 & 11.1 & 8.4 & 10.8 & 12.9 \\
\hline \multirow{3}{*}{ 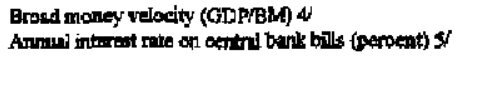 } & 5.0 & 4.3 & 4.1 & 40 & 3.5 & 39 & 3.2 \\
\hline & 23.3 & 11.4 & 8.5 & - & 8.8 & $\ldots$ & 13.0 \\
\hline & \multicolumn{7}{|c|}{ (In millians of Us dollars, undess otherwise indivaled) } \\
\hline 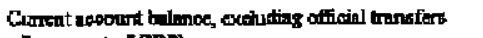 & -128 & -127 & -153 & -170 & -164 & -199 & -174 \\
\hline (m perent of GDP) & .3 .2 & -14.1 & .35 .8 & -167 & -159 & -14.7 & -15.8 \\
\hline 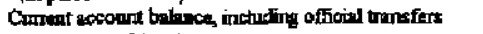 & .73 .3 & $-\infty 0.3$ & 54,4 & -74.6 & -76.8 & -76.5 & -91.4 \\
\hline (ln perdent of GDP) & $-7,8$ & 6.7 & -5.6 & .7 .3 & -75 & -7.1 & $-\mathbf{8 . 3}$ \\
\hline Trade balance & -128 & .113 & 140 & $-1 \leqslant 0$ & .170 & -132 & .168 \\
\hline (In perbent of $C D P$ ) & .124 & -12.5 & -14.4 & -147 & -16.5 & -123 & -152 \\
\hline Expents, fob & 462 & 454 & $\mathbf{5 3 6}$ & 549 & 523 & 601 & 630 \\
\hline (Percent change) & .18 .7 & -18 & 180 & 2.3 & -2.4 & 9.4 & 20.4 \\
\hline Inports, dif tor & 582 & 567 & 676 & 699 & 693 & 733 & 798 \\
\hline (Perpear chenpe) & 8.2 & -2.6 & 19.2 & 1.7 & 2.5 & 4.9 & 15.1 \\
\hline 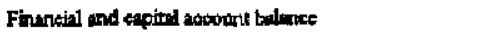 & 116 & 62 & B & $\pi$ & $m$ & B! & 111 \\
\hline (In percent of GDP) & 12.0 & 69 & 7.0 & 7.1 & 7.7 & 7,5 & 10.0 \\
\hline 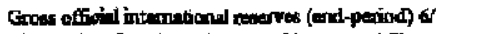 & 123.2 & 156.8 & 190.9 & 209.2 & 206.8 & 237.1 & 240.4 \\
\hline (th wecks of neat yearprajected inporti cif) & 11.3 & 121 & 14.3 & 14.8 & 13.5 & 16.0 & 14.9 \\
\hline 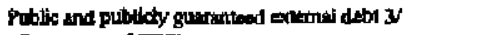 & 739 & 828 & 897 & 912 & 854 & 1.009 & 960 \\
\hline (h percent of GDP) & 78.1 & 91.4 & 863 & 89.4 & 82.9 & 93.6 & 87.0 \\
\hline NPV of poblific and publicly guarartited extemal debr $y$ & ... & 371 & 502 & \$1 & 571 & 699 & 630 \\
\hline (In pereant of GDP) & 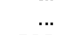 & 63.0 & 539 & $5 \pi 9$ & 555 & 59.2 & 57.1 \\
\hline Dest vervies of & 36.2 & 319 & 24.2 & 45.8 & 33.9 & 37,4 & 35.1 \\
\hline (in percertit of exports of poods \& sarvices) & 6.7 & 3.7 & 3.8 & 7.0 & 53 & 5.3 & 4.7 \\
\hline \multicolumn{8}{|l|}{ Exaturge and } \\
\hline 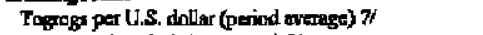 & BH1 & $\mathbf{i}, 022$ & 1,077 & 1,130 & 1,098 & 1,179 & 1,104 \\
\hline NEER, foldperind $(1995=100) \mathrm{g}$ & 69 & 61 & 59 & ... & 62 & t. & 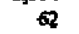 \\
\hline REER ad-pariod $(1995-100) \&$ & 118 & 107 & 108 & - & 117 & 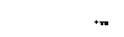 & 118 \\
\hline NEFR, paciod therage $(9995=100) 8$ & 65 & 63 & 6] & $\ldots$ & 61 & ... & 62 \\
\hline REER, period avenge $(1995=100) \&$ & 119 & 110 & 115 & .- & 118 & $\ldots$ & $\$ 19$ \\
\hline Expart prices (U.S. doller, percent chernge) & -18.1 & -7.0 & 13.6 & -4.3 & -119 & 4.7 & 1.6 \\
\hline Copper prive (uS dofler, percent charige) & -38.1 & 5.8 & 18.4 & -11.0 & -12.7 & 13.3 & .7 .0 \\
\hline Impor paices (U.S. doller, percont charger) & -6.8 & -2.4 & 2.5 & $-\$ .2$ & -1.6 & 0.3 & 1.6 \\
\hline Temo of tonde (percent chentig) & -12.1 & 4.9 & 10.8 & 0.9 & -10.4 & 4.4 & 0.0 \\
\hline 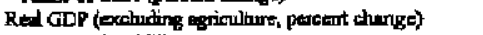 & 1.7 & 2.6 & 11.5 & & 10.7 & . & 5.3 \\
\hline Nominal GDP (billion togrogay) & 817 & 925 & 1,045 & 1,192 & $\$, 131$ & 1,270 & 1,245 \\
\hline Nomtirs GDP (millison U.S. dollens) & 972 & 906 & 970 & 1.020 & 1,030 & 1.078 & 1.104 \\
\hline
\end{tabular}

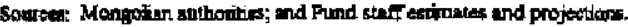

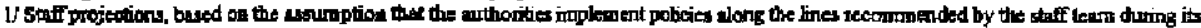

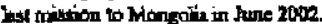

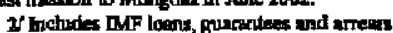

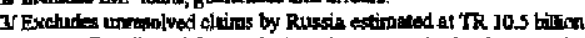

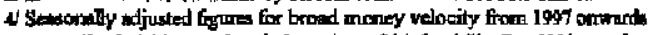

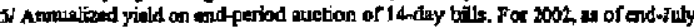

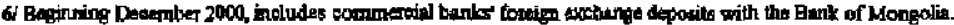

7) For 2002, is of June

a for 2002, as of Aprit 
Table 2. Mongolia: Summary Operations of the General Government, 1998-2002

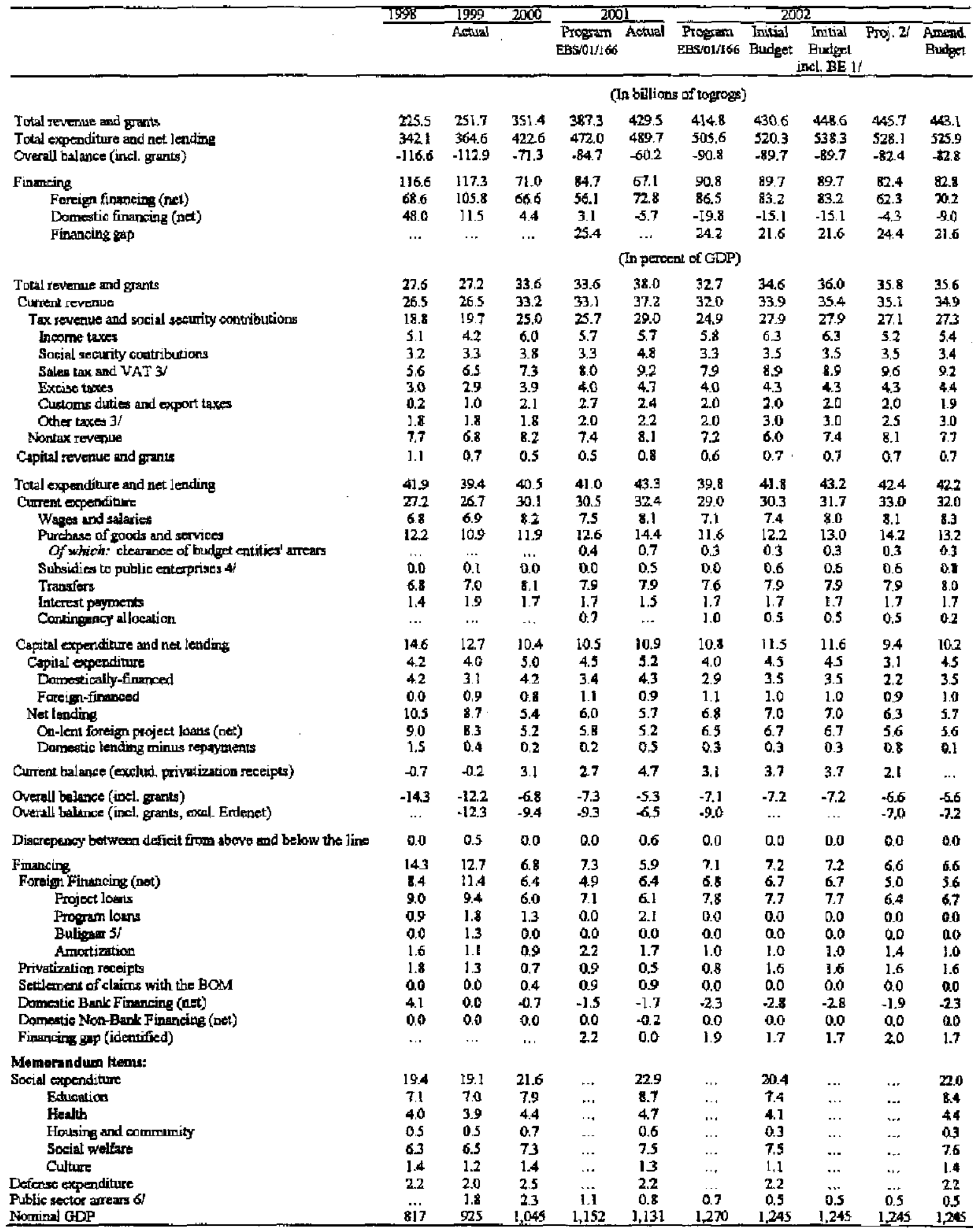

Soures: Ministry of Finaree, and Find staff cotinates and projecticus

$1 /$ Incluales 26 budget entities in the social sectors siated to be dewolved under the governments soeial secter privatization program.

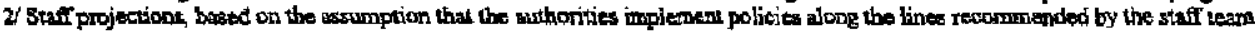

during its lest mission to Mongolia in Junc 2000 .

3 In 2002 the VAT on gold was replaced by a revenue-neutral inirease in the royghy on gold mining, which is included under other taxes.

However, the 2002 budget continnes to reporl the additional revanie from the royraly under the line item domextic VAT.

4'Ecgiman with the projections for 2001 this item includes subsidies to SOE for quasi-fiscal activities which previousiy bad becn neconded under purcheses of goods and sesvicter.

5/ Equals transfer from BOM for acceptance of contingent liahility.

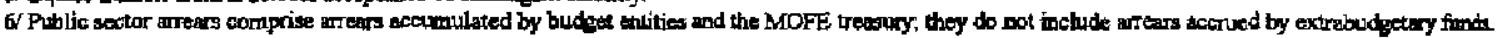


Table 3. Mongolis: Quantitative Performance Criteria and Indicative Targets Under the PRGF Arangement, 2001-02 1/

\begin{tabular}{|c|c|c|c|c|c|c|c|c|c|c|c|c|}
\hline & \multicolumn{7}{|c|}{2001} & \multicolumn{5}{|c|}{2002} \\
\hline & \multirow{2}{*}{$\begin{array}{r}\text { End-Juns: } \\
\text { Aetual }\end{array}$} & & \multirow{2}{*}{ 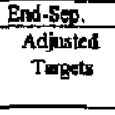 } & \multirow[b]{2}{*}{ Aetunl } & \multicolumn{3}{|c|}{ End-Dex. } & \multicolumn{3}{|c|}{ Ead-Jine } & \multirow{2}{*}{ 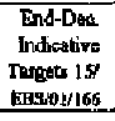 } & \multirow{2}{*}{$\begin{array}{l}\text { Ėnd-Dow } \\
\text { Fтoj. } 16\end{array}$} \\
\hline & & 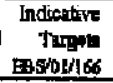 & & & 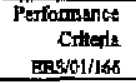 & $\begin{array}{l}\text { Adjusled } \\
\text { Tatgets }\end{array}$ & Actud & 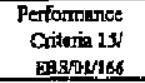 & $\begin{array}{l}\text { Adjusted } \\
\text { Turgets }\end{array}$ & Astual & & \\
\hline 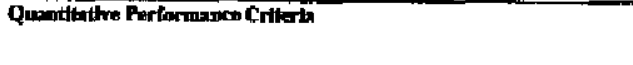 & \multicolumn{12}{|c|}{ (In billions of togrago) } \\
\hline 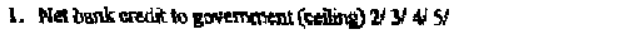 & -8.0 & .7 .1 & 12.5 & .1 .3 & .16 .8 & 46.2 & .18 .7 & 3.8 & 1.0 & 9.3 & .29 .6 & 29.8 \\
\hline 2. Net domestis absots of the Baaks of Monsolit (stock, cosiline) $46 / 7 / \approx$ & -2.7 .7 & -24.8 & -13.2 & -22.0 & -29.9 & -27.3 & -30.4 & .29 .4 & .27 .7 & -10.1 & -40.4 & -53.5 \\
\hline \multirow[t]{2}{*}{ 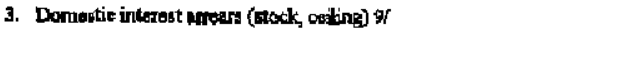 } & 0.0 & 8.0 & 0.0 & e.0 & 0.0 & 0.0 & 0.0 & 0.0 & 0.0 & 0.0 & 0.0 & 0.0 \\
\hline & \multicolumn{12}{|c|}{ (fn millions of U.S. dollars, unitess otherwise indicnted) } \\
\hline 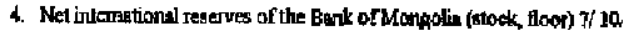 & 1320 & 148.2 & 130.9 & $1+0,1$ & $\$ 60.6$ & 159.7 & 158.9 & 978.0 & J66.8. & 169.3 & 185.6 & 196.0 \\
\hline \multicolumn{13}{|l|}{ 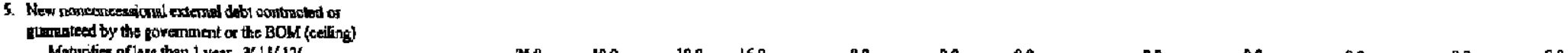 } \\
\hline 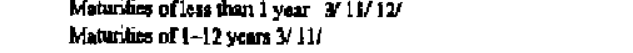 & $\begin{aligned} 250 \\
0.0\end{aligned}$ & $\begin{array}{r}10.0 \\
0.0\end{array}$ & $\begin{array}{r}10.0 \\
0.0\end{array}$ & $\begin{array}{r}16.0 \\
0.0\end{array}$ & $\begin{array}{l}0.0 \\
0.0\end{array}$ & $\begin{array}{l}0.0 \\
0.0\end{array}$ & $\begin{array}{l}0.0 \\
0.0\end{array}$ & 0.0 & $\begin{array}{l}0.0 \\
0.0\end{array}$ & $\begin{array}{l}0.0 \\
0.0\end{array}$ & $\begin{array}{l}0.0 \\
0.0\end{array}$ & $\begin{array}{l}0.0 \\
0.0\end{array}$ \\
\hline 6. Extemal paymethe arears (stock, ceiline) \& IV & D. D & 00 & 0.0 & 0.0 & D.0. & 0.0 & 4.8 & 0.0 & 0.0 & 0,0 & 0.0 & o: 0 \\
\hline \multicolumn{13}{|l|}{ Indleattre Iarnot } \\
\hline 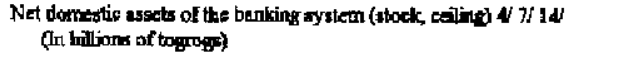 & 91.1 & 84.3 & 104.0 & 98.1 & 70.0 & 71.7 & 113.2 & 89.2 & 93.1 & 178.3 & 64.7 & 1393 \\
\hline \multicolumn{13}{|l|}{ Memantadum tormu: } \\
\hline 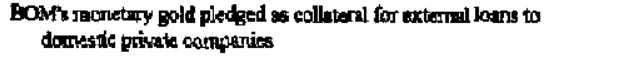 & 30.0 & 12.0 & & 19.2 & 0.0 & & 00 & 0.0 & & 0.0 & 0.0 & 0.0 \\
\hline 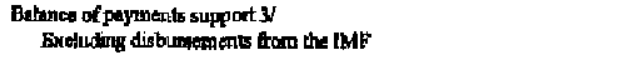 & 5.2 & 24.5 & & 52 & 22.5 & & 21.6 & 5.2 & & 2.0 & 20.5 & 21.6 \\
\hline 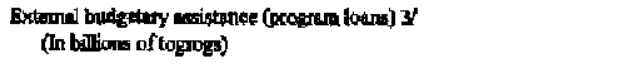 & 5.7 & 25.4 & & 2.7 & 25.4 & & 23.8 & 6.1 & & 2.2 & 242 & 24.4 \\
\hline 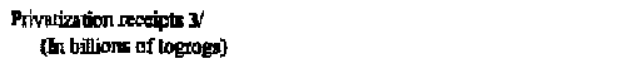 & 1.1 & 3.4 & & 1.4 & 10.2 & & 5.6 & 0.0 & & 1.6 & 9.7 & 19.5 \\
\hline $\begin{array}{l}\text { Transfift forn the BOM to gavernment } 3 \text {, } \\
\text { (In billions of togrogs) }\end{array}$ & 9.8 & 9.8 & & 9.8 & 113 & & 123 & 0.0 & & 3.1 & 1.7 & 5.0 \\
\hline Rescrve rnouey (th tillions of togrags) & 154.3 & 1513 & 153.3 & 153.1 & 197.6 & 147.6 & 144.1 & 157.4 & 158.0 & 176.0 & 163.6 & 162.7 \\
\hline
\end{tabular}

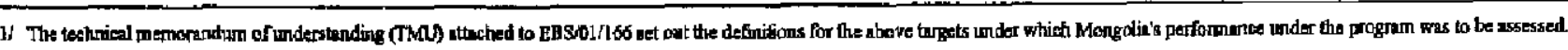

21. Defined as Jel claims of gevertument in the mometary servey.

3. Curnulative from the begining of the year.

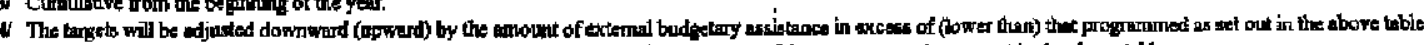

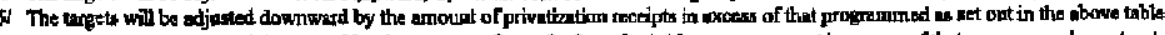

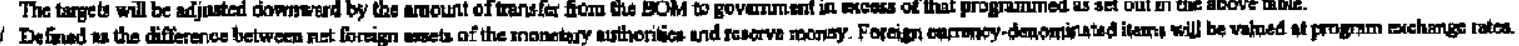

7 The

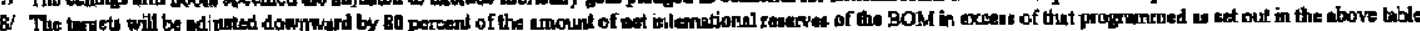

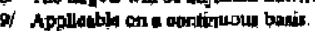

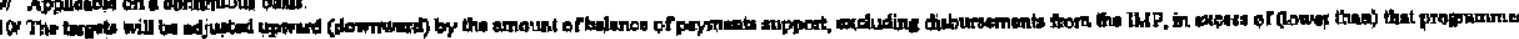

in wot cat in the aboves trible.

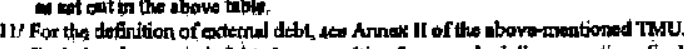

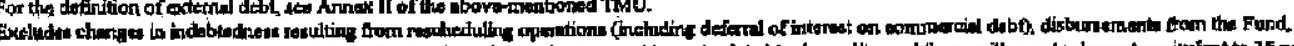

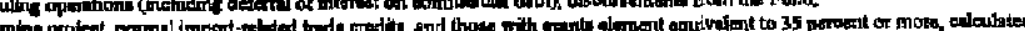

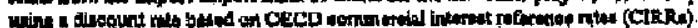

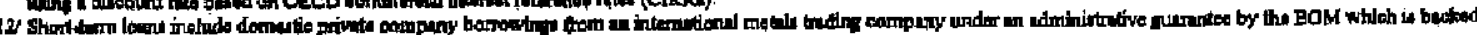

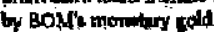

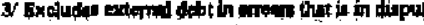

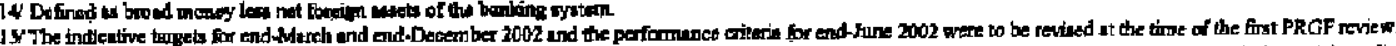

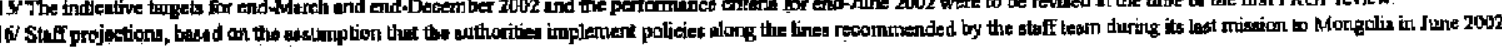


Table 4. Mongolia: Monetary Aggregates, 1998-2002 I/

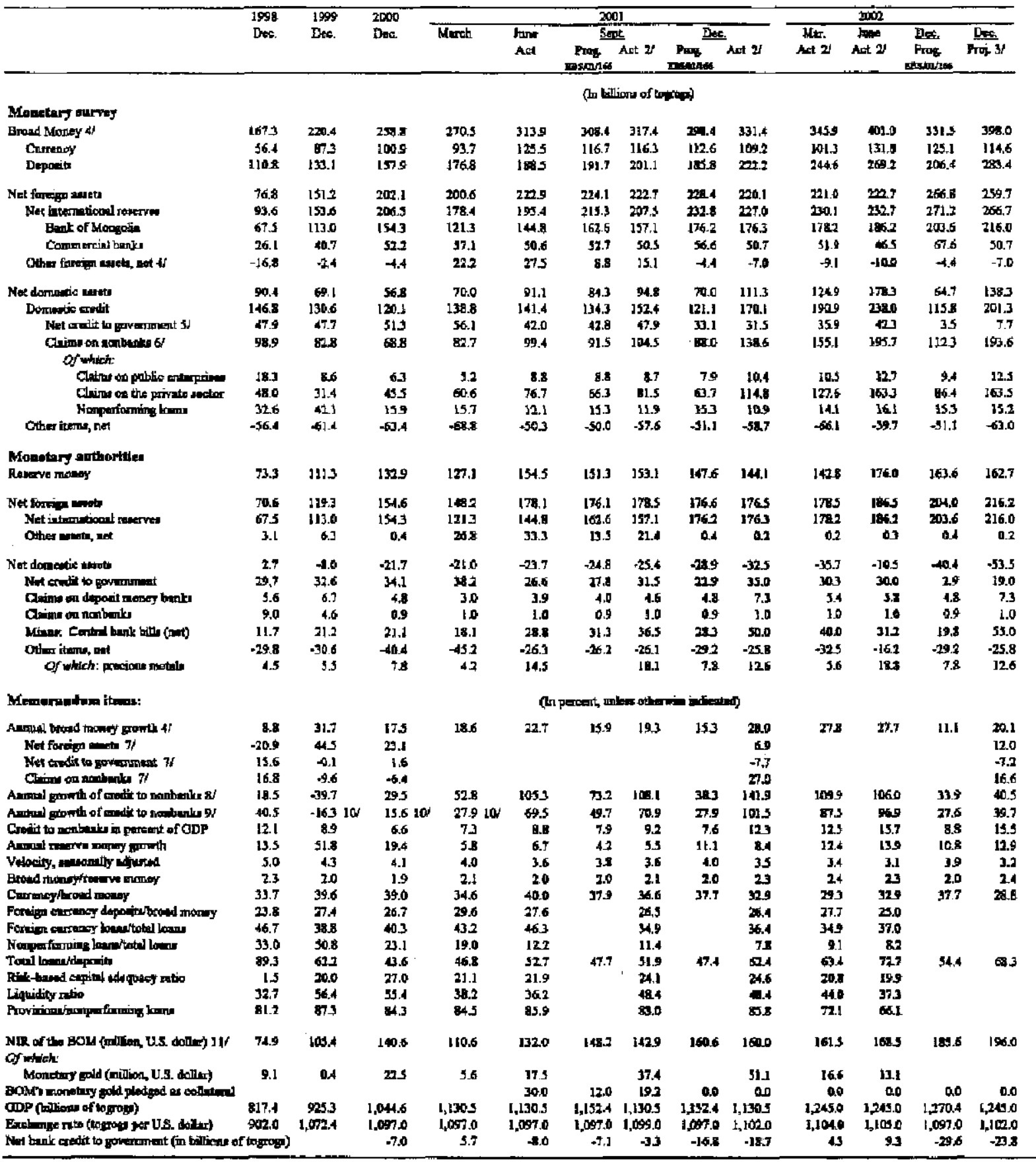

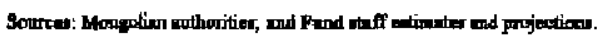

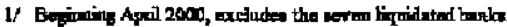

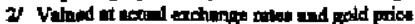

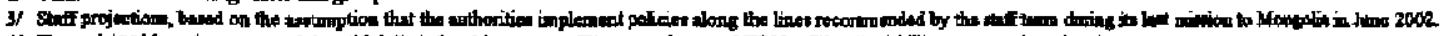

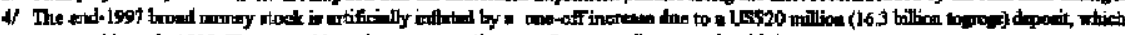

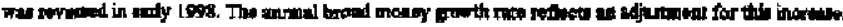

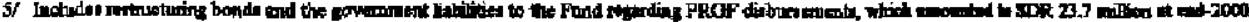

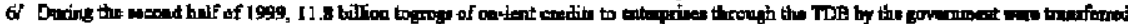

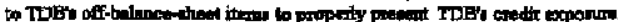

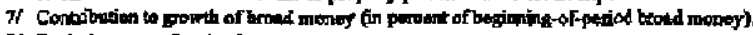

8 Exciledes nespertaraing lean.

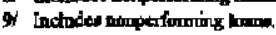

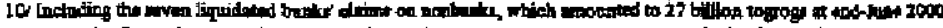

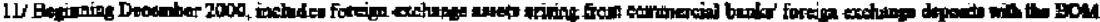

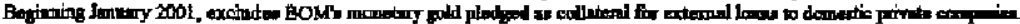


Table 5. Mongolia: Balance of Payments, 1998-2002

\begin{tabular}{|c|c|c|c|c|c|c|c|}
\hline \multirow[t]{2}{*}{$:$} & \multirow[t]{2}{*}{$1,99 \mathrm{~s} \mathrm{~W}$} & 1999 & 2000. & 3001 & rag1 & 20002 & 2002 \\
\hline & & Act & \multicolumn{2}{|c|}{$\begin{array}{r}\text { Prog } \\
\text { ActEes/0u/166 } \\
\end{array}$} & \multirow{2}{*}{$\frac{\text { Fint. }}{2170.0}$} & 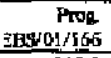 & \multirow{2}{*}{$\frac{\text { Proj. } 2 f}{-168.0}$} \\
\hline Trade halmen & -120.1 & -173.1 & .140 .2 & -149.7 & & +1322 & \\
\hline Expocts, fib. & $\$ \mathbf{6 2 . 3}$ & $45+2$ & 535.8 & 549,2 & 523.2 & Gal.0 & 630.0 \\
\hline Copper & 124.8 & 119.2 & 1603 & 151.2 & $147 !$ & 176.5 & 143.6 \\
\hline Importh, a.if. $\mathrm{k} /$ & $+382,4$ & .567 .3 & -576.9 & -698.9 & -693.1 & .733 .2 & .798 .0 \\
\hline Servieen, net & - & -7.4 & 8.5 & -13.2 & -22.2 & -15.7 & -26.1 \\
\hline Reseipt & 77,9 & 100.6 & 104.2 & 507.9 & 113.5 & 106.0 & 120.5 \\
\hline Paymantu & -89.8 & -108.0 & $-\$ 12.7$ & -116.0 & -135.7 & -121.7 & $-146,6$ \\
\hline Incosme, aut & 0.4 & -12.8 & -12.4 & -16.2 & 2.9 & +19.6 & -5.4 \\
\hline Offistal in tortur paytiveque $4 J$ & -9.2 & -7.9 & -9.3 & -9.0 & -9.0 & -119 & -108 \\
\hline Private turteqnited truafors & 25 & 5.9 & 8.8 & 9.0 & 250 & 9.0 & 250 \\
\hline $\begin{array}{l}\text { Current mecount baleace, } \\
\text { erejudiug anciul tranufers }\end{array}$ & -138.8 & -127.4 & $-i 53.0$ & -50.1 & -164.2 & -138.5 & -174 \\
\hline \multirow{2}{*}{$\begin{array}{l}\text { Publie paroquiled tranfers, weth } \\
\text { Offieral grand }\end{array}$} & 53.2 & 67.1 & 98.6 & 95.5 & 87.4 & 62.0 & 83.0 \\
\hline & 45.8 & 60.2 & 36.2 & 85.3 & $\tau 2 . \mathrm{I}$ & 75.0 & 74.9 \\
\hline 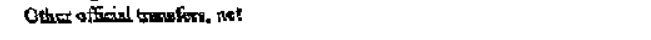 & 7.4 & 6.9 & 12.4 & 102 & 15.3 & 7.0 & 9,8 \\
\hline Flancial and capdial moconnt & 116,4 & 0.2 .4 & 68.3 & 72.0 & 79.0 & 81.2 & 1105 \\
\hline \multirow{2}{*}{$\begin{array}{l}\text { Disect invertrumt } \\
\text { Losst }\end{array}$} & IB.9 & 34.2 & \$O.0 & 45.3 & 43.0 & 14.4 & $5 B .2$ \\
\hline & 93.7 & 109.1 & 90.5 & 79.1 & T7.8 & 97.3 & 85.5 \\
\hline Medium- and long-teris, net & $\$ 3.7$ & 97.2 & 80.5 & 70.3 & 6a.s & 50.3 & 79.5 \\
\hline $\begin{array}{l}\text { Disburjementh } \\
\text { Pnthis enctor }\end{array}$ & 1225 & 173.7 & 151.0 & 153.6 & 367.2 & 163.8 & 172.8 \\
\hline Pablic acter & 93.7 & 101.8 & 71.0 & 72.6 & B4.2 & 83.8 & 72.3 \\
\hline Pringte wector & 28.8 & $\pi .9$ & 80.0 & 81.0 & 80 & 82.0 & 100.5 \\
\hline Amortizention & $-28,8$ & -75.6 & -70.5 & 80.5 & -98.4 & -75.6 & $-93,3$ \\
\hline Peblic mector & -18.6 & -226 & -8.5 & -21.4 & $-1 B .0$ & -16.1 & -16.7 \\
\hline Privite sector & -10.2 & -540 & -120 & -62.2 & -80.5 & -59.1 & -36.6 \\
\hline Short-tem, net & 0.0 & Il, 9 & 10.0 & 5.0 & 9.0 & 7.0 & 7.0 \\
\hline 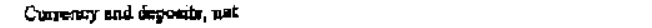 & 40.0 & -227 & -125 & -3.5 & 3.6 & -10.0 & alo \\
\hline 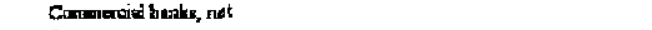 & 40.0 & -229 & $\cdot 13.5$ & $-1,0$ & 3.6 & -10.0 & 00 \\
\hline Oeder & $\ldots$ & 0.2 & 1.0 & 0.5 & 0.0 & 0.0 & a.a \\
\hline 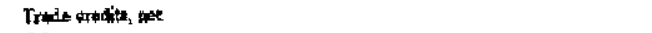 & 6.6 & -129 & -9.7 & -90 & -15.3 & $-10,0$ & $-16 a$ \\
\hline $\begin{array}{l}\text { Others, net } \\
\text { Errurs and ominiteas }\end{array}$ & -42.9 & $\begin{array}{r}-15.3 \\
12.7\end{array}$ & +0.0 & $\begin{array}{r}39.9 \\
0.0\end{array}$ & $\begin{array}{r}-30.0 \\
12.5\end{array}$ & -40.5 &.+8.18 \\
\hline Oworall balance & -28.8 & 14.7 & 34.1 & -1.6 & 14.7 & 4.7 & 19.1 \\
\hline Financiag & $\mathbf{7 8 , 8}$ & -14.7 & -34.1 & 2.6 & -14.7 & 4.7 & -19.1 \\
\hline 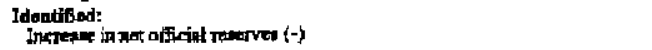 & $\begin{array}{l}28.8 \\
15.0\end{array}$ & $\begin{array}{l}-14.7 \\
-30.5\end{array}$ & $\begin{aligned}-34.1 \\
.35 .2\end{aligned}$ & $\begin{array}{l}-25.3 \\
.25 .3\end{array}$ & $\begin{array}{l}-14.7 \\
-19.5\end{array}$ & -35.8 & $\begin{array}{l}-45.0 \\
-41.2\end{array}$ \\
\hline Whe of OAF aratis (t) & -1.3 & 4.2 & 4,7 & -5.9 & -1.7 & -7.9 & -7.6 \\
\hline Increare in proll officiel ravaryee ( -3 & 16.3 & -34.7 &,- 35.9 & -18.3 & -17.8 & 27.9 & -33.5 \\
\hline 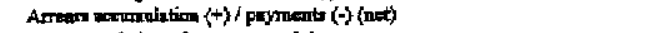 & 13.8 & 20 & -15.8 & 0.0 & 4.8 & 0.0 & -4.8 \\
\hline A & 13.8 & 15.8 & 0.0 & 0.0 & 48 & 0,0 & 0.0 \\
\hline 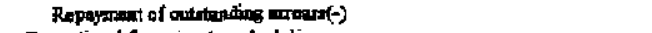 & 0.0 & -13.8 & $-15,8$ & 0.0 & 0.0 & 0.0 & $-4,5$ \\
\hline Enceptinum finaraing / reuchoduting & 0.0 & 19.8 & 16.8 & 0.0 & 0.0 & 0.0 & 0,0 \\
\hline 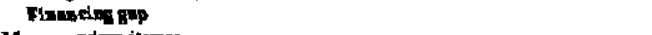 & 8.0 & $\mathbf{0 . 0}$ & 0.0 & 798 & 0.0 & 31.1 & 36.9 \\
\hline Mowornad ma ditame: & & & & & & & \\
\hline Current worount balunce, areludins & & & & & & & \\
\hline 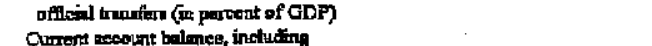 & -13.2 & -14.1 & $\cdot 15.8$ & -16.7 & -15.9 & -147 & .15 .8 \\
\hline 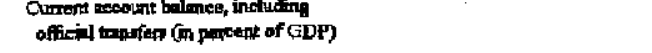 & -7.6 & -6.7 & $-5,6$ & -73 & -7.5 & -7.1 & 8.3 \\
\hline 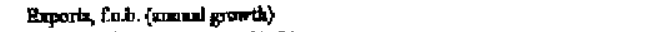 & -18.7 & -1.8 & 180 & 2.3 & .14 & 9.4 & 20.4 \\
\hline 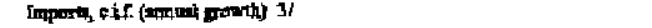 & 8.2 & .2 .6 & 19.2 & 1.7 & 1.5 & 4.9 & I5.1 \\
\hline Export wolume prowth & -0.7 & 5.6 & 3.8 & 6.9 & 10.8 & 4.5 & 18.5 \\
\hline Lonport valure growth 3) & I6.1 & -0.2 & 16.2 & 7.2 & 4.3 & 1.5 & 13.3 \\
\hline Expont prica inden change & -18.1 & -7.0 & 13.6 & 4.3 & -119 & 4.7 & 1.6 \\
\hline lmport wios inder ateripgt & -6.8 & -2.1 & 23 & -5.2 & -1.6 & 0.3 & 1.6 \\
\hline Tradp baluge fon persent GDP) & -12.4 & $\cdot 32.5$ & $-14,4$ & -14.7 & -161 & -123 & -15.3 \\
\hline Not officiel newrves (and-period) 6/7/ & 74.9 & 105.4 & 140.6 & 160.6 & 160.1 & 196.4 & 2013 \\
\hline 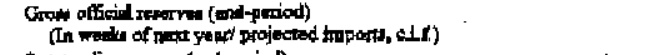 & $\begin{array}{r}1 \pm 3.2 \\
11.3\end{array}$ & $\begin{array}{r}196.8 \\
12.1\end{array}$ & $\begin{array}{r}190.9 \\
14.3\end{array}$ & 200.2 & $\begin{array}{r}205.8 \\
13.5\end{array}$ & $\begin{array}{r}207.3 \\
16.0\end{array}$ & $\begin{array}{r}240.4 \\
14.9\end{array}$ \\
\hline Oututindins wrewe (and-period) & 13.8 & 15.8 & 0.0 & D. & 4.8 & 0.0 & 0.0 \\
\hline 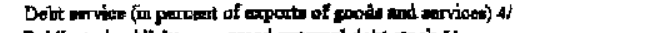 & 6.7 & 5.7 & 3.8 & 7.0 & 3.3 & 5.3 & 4.9 \\
\hline 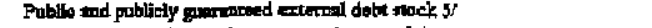 & 759 & 028 & $\mathbf{8 3 7}$ & 912 & 894 & 1009 & 960 \\
\hline 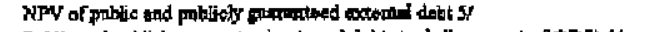 & $\ldots$ & 571 & $\mathbf{5 4 2}$ & 591 & 571 & 639 & 630 \\
\hline 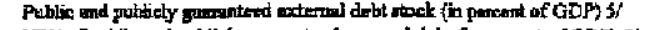 & 78.1 & 91.4 & 863 & gas & 82.9 & 93.6 & 87,0 \\
\hline 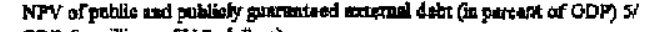 & $\cdots$ & 63.0 & 35.9 & 57.5 & $\$ 5.5$ & 59.2 & 57.1 \\
\hline GDP (in millionn of US. dotling? & 972 & 906. & 970 & 1020 & 1,030 & 1,078 & 1,104 \\
\hline
\end{tabular}

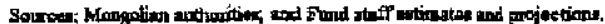

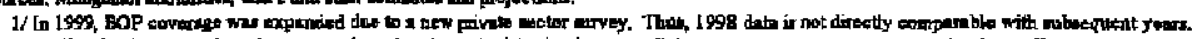

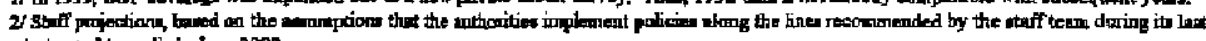

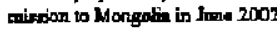

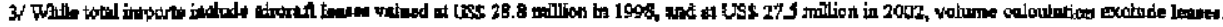

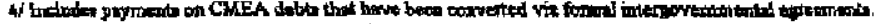

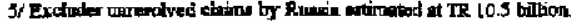

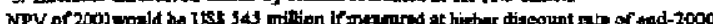

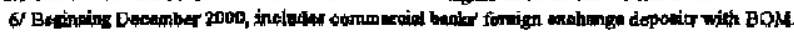

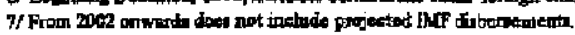


Table 6. Mongolia: External Debt and Debt Service, 2000-07 1/

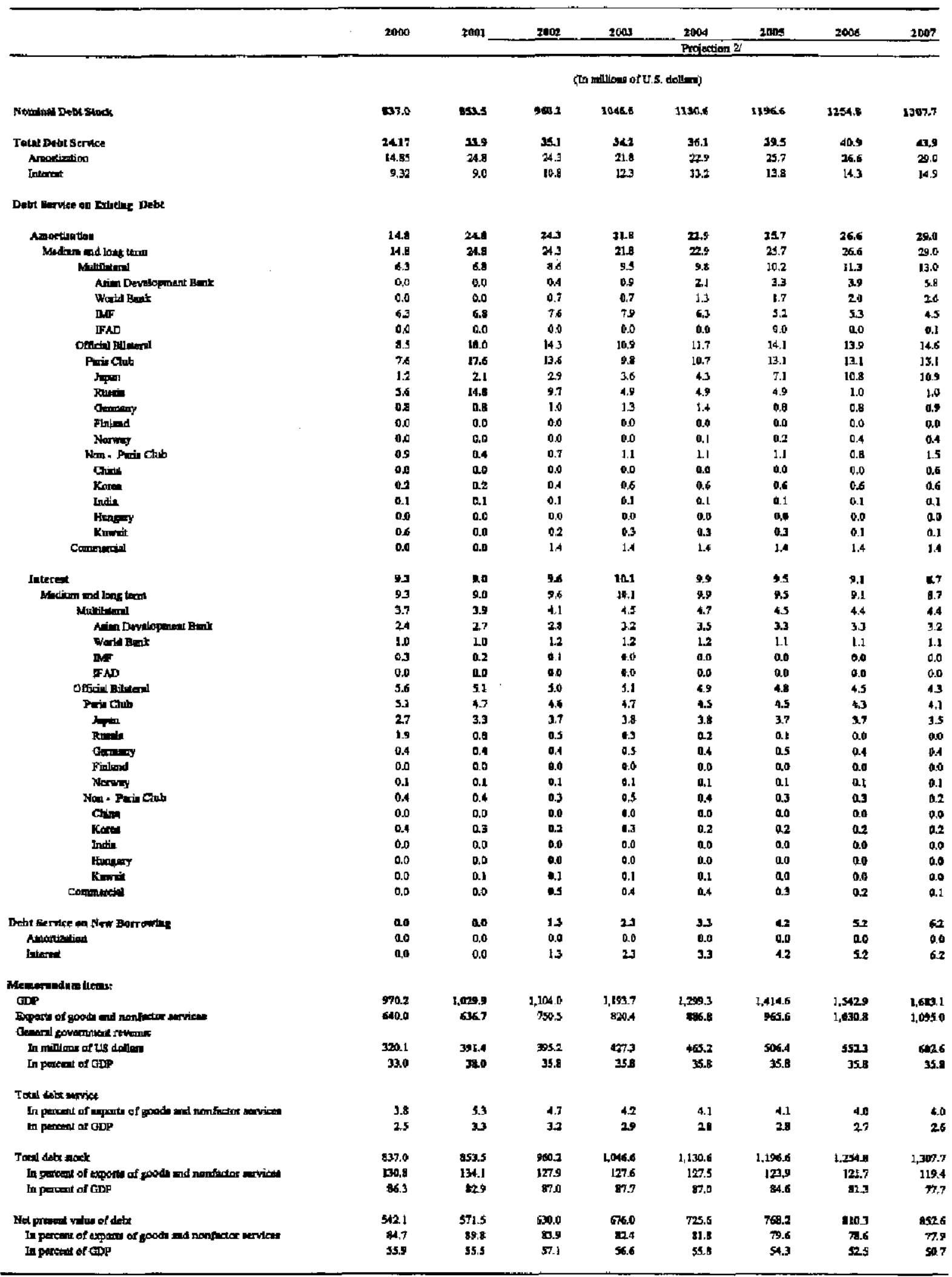

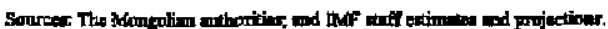

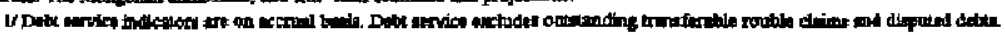

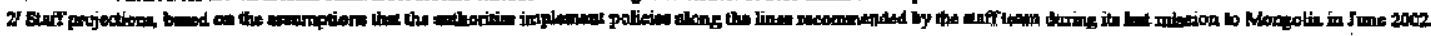


Table 7. Mongolia: Structural Benchmarks and Performance Criteria

Under the PRGF Arrangement

\section{A. Structural Performance Criteria}

1. Secure Parliamentary approval of amendment to Budget Law to clarify and strengthen the accountability of local government officials with respect to the control and reporting of bank accounts and the enforcement of Cabinet regulations and directives from the head of treasury, including by specifying the penalties for arrears accumulation and the misuse of public funds.

2. Secure Parliamentary approval of legislation to centralize the proceeds from VAT collected at all levels of government and assign a fixed percentage of VAT receipts to the local government sector as a whole.

3. Complete transfer of all pilot entities' deposits to the TSA, adopt a Cabinet resolution to extend the TSA to all line ministries and Ulaanbaatar City and close all their off-budget accounts, and initiate transfer of remaining central government deposits to the TSA.

4. Obtain Parliamentary approval of 2002 Budget in line with the macroeconomic framework agreed with the IMF, including adequate allocations for a continuing reduction of arrears and expenditure saving reforms and a wage and employment policy consistent with the maintenance of current spending within the agreed envelope.

5. Require local governments to adopt the same reporting standards on bank accounts as the central government and to provide monthly reports on their account balances.

\section{B. Structural Benchmarks}

6. Enforce legal requirement to report semi-annually to the MOFE on all government entities, including EBFs, and prepare semi-annual report for consolidated central government and available data on local governments, including comprehensive data on public employment, with the first semi-annual report to cover data for January-June 2001.
End- Observed.

December

2001

End-

December

2001

End-

December

2001

EndDecember 2001

End-April 2002

EndSeptember 2001

Partly completed; the consolidated fiscal report for the first half of 2001 contained serious mistakes, owing in part to serious technical constraints within the MOFE. The authorities recently completed the preparation of an annual 
7. Submit bill to the Parliament to reassign the Corporate Income Tax and the excise tax on alcohol to the central budget starting in 2002 and develop a new equalization transfer model to be used as a guide for the 2002 budget.

8. Adopt joint action program agreed by Treasury and SFSA to monitor budget entities' bank accounts, ensure that payments arrears problems are properly addressed, and establish a time-bound plan for the progressive reduction and elimization of arrears.

9. Adopt legislation requiring all general government entities, inciuding EBFs, to report quarterly to the MOFE, including on the number of staff employed disaggregated by agency.

10. Implement arrears reduction plan and meet arrears reduction targets set for each debtor agency under the Treasury/SFSA joint action program.

11. Complete transfer of all central government and Ulaanbaatar City deposits and EBFs to the TSA, close all off-budget accounts held by central government and Ulaanbaatar City, and ensure that at least 75 percent of total central government and Ulaanbaatar City expenditures are routed through the TSA system.

12. Adhere to best intemational standards for the licensing of new banks, including by limiting prospective applicants only to the largest and most reputable institutions from countries with proven records of effective consolidated supervision, and consult with IMF staff about the appropriate interpretation of these standards when considering applications for new bank licenses.
End- Partly completed; transfers

Decernber from the central budget to local 2001 governments are still based on negotiations.

End- Completed in June 2002.

December

2001

End- Observed.

December

2001

End-June 2002

End-June 2002

Continuous Ongoing.
Not observed.

In light of the delay in completing item 8 , the implementation of the arrears reduction plan could now be assessed in December 2002.

Not observed.

Given technical constraints, rephased TSA reforms are under implementation. 
Table 8. Mongolia: Medium-Term Macroeconomic Framework, 1999-2007

(In perents of GDP, wless otherwise indieated)

\begin{tabular}{|c|c|c|c|c|c|c|c|c|c|}
\hline & 1999 & 2000 & 2001 & 2002 & 2003 & 2004 & 2005 & 2006 & 2007 \\
\hline \multicolumn{10}{|l|}{ Real nector } \\
\hline Real GDP (percent change) & 3.2 & 1.1 & 1.1 & 3.9 & 5.0 & 6.0 & 6.0 & 60 & 6.0 \\
\hline GDP deflator (percent changer) & 9.7 & 11.7 & 7.0 & 6.0 & 5.0 & 5.0 & 9.0 & 5.0 & 5.0 \\
\hline Contsumer prices (period average, peroent shenge) & 7.6 & 11.6 & 8.0 & 5.0 & 5.0 & 3.0 & 5.0 & 5.0 & 5.0 \\
\hline Conmuner pricen (ond-period, pereent change) & 10.0 & 8.1 & 8.0 & 6.0 & 5.0 & 5.0 & 5,0 & 5.0 & 5.0 \\
\hline Per capita GDP (in U.S. dollars) & 383.9 & 408.8 & 427.5 & 451.5 & 480.9 & 515.8 & 553.3 & 594.4 & 638.9 \\
\hline \multicolumn{10}{|l|}{ Saving and investment $2 /$} \\
\hline Gross domastic investmont & 37.0 & 32.9 & 22.9 & 24.3 & 25.1 & 25.6 & 26.2 & 26.8 & 27.3 \\
\hline Government & 14.7 & 12.1 & 10.4 & 8.7 & 9.0 & 9.0 & 9.1 & 9.1 & 9.2 \\
\hline Private & 22.4 & 20.8 & 12.5 & 15.6 & 16.1 & 16.6 & 17.1 & 17.7 & 18.1 \\
\hline Grogs domestic anving & 14.4 & 42 & 4.2 & 6.8 & 109 & 13.2 & 15.2 & 16.3 & 172 \\
\hline Goverumeat & 10.0 & 15.5 & 16.6 & 14.6 & 14.8 & 15.1 & 15.7 & 15.9 & 16.3 \\
\hline Private & 4.4 & -11.4 & -12.4 & -7.8 & -3.9 & -1.9 & -0.4 & 0.5 & 0.9 \\
\hline Irvestment-aving bolance & -6.7 & -5.6 & $-7,5$ & -8.3 & -7.1 & -6.1 & -5.0 & -5.0 & -3.1 \\
\hline Grows nationsal saving & 30.3 & 27.3 & 15.4 & 16.1 & 18.1 & 19.6 & 21.2 & 21.8 & 22.2 \\
\hline \multicolumn{10}{|l|}{ Fiscal necounts } \\
\hline Total revenos and gronts & 27.2 & 33.6 & $\mathbf{3 8 . 0}$ & 35.8 & 35.8 & 35.8 & 35.8 & 35.8 & 35.8 \\
\hline Domentic reventre & 26.5 & 33.2 & 37.2 & 35.1 & 35.1 & 35.1 & 35.1 & 35.1 & 35.1 \\
\hline Tax reveribe & 19.7 & 25.0 & 29.0 & 27.1 & 27.2 & 27.3 & 27.4 & 27.5 & 27.6 \\
\hline Nontex reveruse & 6.8 & 8.2 & 8.1 & 8.1 & 7.9 & 7.8 & 7.7 & 7.6 & 7.3 \\
\hline Grant: & 0.7 & 0.5 & 0.8 & 0.7 & 0.7 & 0.7 & 0.7 & 0.7 & 0.7 \\
\hline Totol expenditure and net lending & 39.4 & 40.5 & 43.3 & 42.4 & 41.9 & 41.3 & 40.8 & 40.4 & 39.9 \\
\hline Current expenditure & 26.7 & 30.1 & 324 & 33,0 & 32.4 & 31.8 & 31.2 & 30.8 & 30.2 \\
\hline Wages and starios & 6.9 & 8.2 & 8.1 & 8.1 & 8.0 & 7.9 & 7.7 & 7.6 & 7.4 \\
\hline Goods and services & 109 & 11.9 & 14.4 & 14.2 & 14.1 & 13.9 & 13.9 & 13.3 & 13.1 \\
\hline Interest payments & 1.9 & 1.7 & 1.5 & 1.7 & 1.3 & 1.0 & 1.0 & 0.9 & 0.9 \\
\hline Other & 7.1 & 8.2 & 8.4 & 9.0 & 9.0 & 9.0 & 9.0 & 8.9 & 8.8 \\
\hline Capital expenditure and net lending & 12.7 & 10.4 & 10.9 & 9.4 & 9.5 & 9.5 & 9.6 & 9.6 & 9.7 \\
\hline Current balance & +0.2 & 3.1 & 4.7 & 2.1 & 2.7 & 3.3 & 3.9 & 4.3 & 4.9 \\
\hline Overall bulance (including grants) & -12.2 & -6.8 & -5.3 & -6.6 & -6.1 & -5.5 & -5.0 & -4.6 & -4.1 \\
\hline Foreign financing & 11.4 & 6.4 & 6.4 & -5.0 & 3.1 & 4.6 & 4.1 & 4.0 & 3.6 \\
\hline \multicolumn{10}{|l|}{ Monetary sector } \\
\hline Brogd money (pertoent change) & 31.7 & 17.5 & $\mathbf{2 8 . 0}$ & 20.1 & 12.1 & 12.3 & 12.3 & 12.3 & 11.3 \\
\hline Velocity (GDPMZ) & 4.3 & 4.1 & 3.5 & 3.2 & 3.1 & 3.0 & 3.0 & 3.0 & 3.0 \\
\hline \multicolumn{10}{|l|}{ Bulabee of payments } \\
\hline Exports (percent ohalage) & -1.8 & 18.0 & -2.4 & 20.4 & 10.3 & 8.9 & 9.5 & 7.0 & 6.4 \\
\hline Imports (percent change) & -26 & 192 & 25 & 15.1 & 4.8 & 5.9 & 7.0 & 6.5 & 6.2 \\
\hline Current account balamoe (exoluding officinl tranfers) & -14.1 & -15.8 & -15.9 & -15.8 & -13.1 & -11.6 & -10.1 & -9.7 & -9.4 \\
\hline Current account tralagce (moluding official transfera) & .6 .7 & -5.6 & -7.5 & -8.3 & -7.1 & -6.1 & -5.0 & -5.0 & -5.1 \\
\hline Capital and financial account balance & 6.9 & 7.0 & 7.7 & 10.0 & 8.0 & 6.8 & 6.7 & 6.2 & 6.2 \\
\hline Overall balanoe & 1.6 & 3.5 & 1.4 & 1.7 & 1.0 & 0.8 & 1.7 & 1.2 & 1.1 \\
\hline Finenoing gap (in millions of U.S. dollars) & 0.0 & 0.0 & 0.0 & 26.9 & 20.3 & 16.7 & 5.3 & 0.0 & 0.0 \\
\hline \multicolumn{10}{|l|}{ Groes official reserves } \\
\hline (in millions of U.S. collers) & 156.8 & 190.9 & 206.8 & 240.4 & 264.4 & 284.7 & 308.2 & 321.9 & 336.4 \\
\hline (in weeks of inports of goodh and services) & 10.3 & 12.0 & 11.4 & 12.6 & 13.1 & 13.2 & 13.4 & 13.2 & 13.0 \\
\hline \multicolumn{10}{|l|}{ Delut indicators } \\
\hline Total public debt & 100.1 & 94.7 & $8 ?, 6$ & 88.8 & 87.9 & 87.0 & 84.6 & 81.4 & 78.1 \\
\hline of which: external debt & 91.4 & 86.3 & 82.9 & 87.0 & 87.7 & 87.0 & 84.6 & 81.3 & 77.7 \\
\hline (in mitlions of U.S. dollens) & 327.8 & 837.0 & 893.5 & 960.2 & $1,046.6$ & $1,130.6$ & $1,196.6$ & $1,254.8$ & $1,307.7$ \\
\hline NPV of tatal gublic debt & 71.8 & 64.3 & 60.2 & 58.9 & 56.8 & 55.8 & 54.3 & 52.6 & 51.1 \\
\hline of which: external debt & 63.0 & 55.9 & 55.5 & 57.1 & 56.6 & 55.8 & 54.3 & 52.5 & 50.7 \\
\hline (in millions of U.S. dollars) & 570.5 & 542.1 & 571.5 & 630.0 & 676.0 & 725.6 & 768.2 & 810.3 & 852.6 \\
\hline External public debt service 3 / & 5.7 & 3.8 & 5.3 & 4.7 & 4.2 & 4.1 & 4.1 & 4.0 & 4.0 \\
\hline
\end{tabular}

Sources: Mongolien suthoritiea; and staff eatimates and projection.

1) Staff projeetions, bened on the assumption that the authorities implement policies aloatg the lines recoramended by the staff team during it lant mission to Mongolia in June 2002.

2 Up to 2000 , the authorities' extimates.

3/ In percent of exports of goods and nonfuctor services. 
Table 9. Mongolia: Fund Position and Indicators of Fund Credit, 2000-07 1/

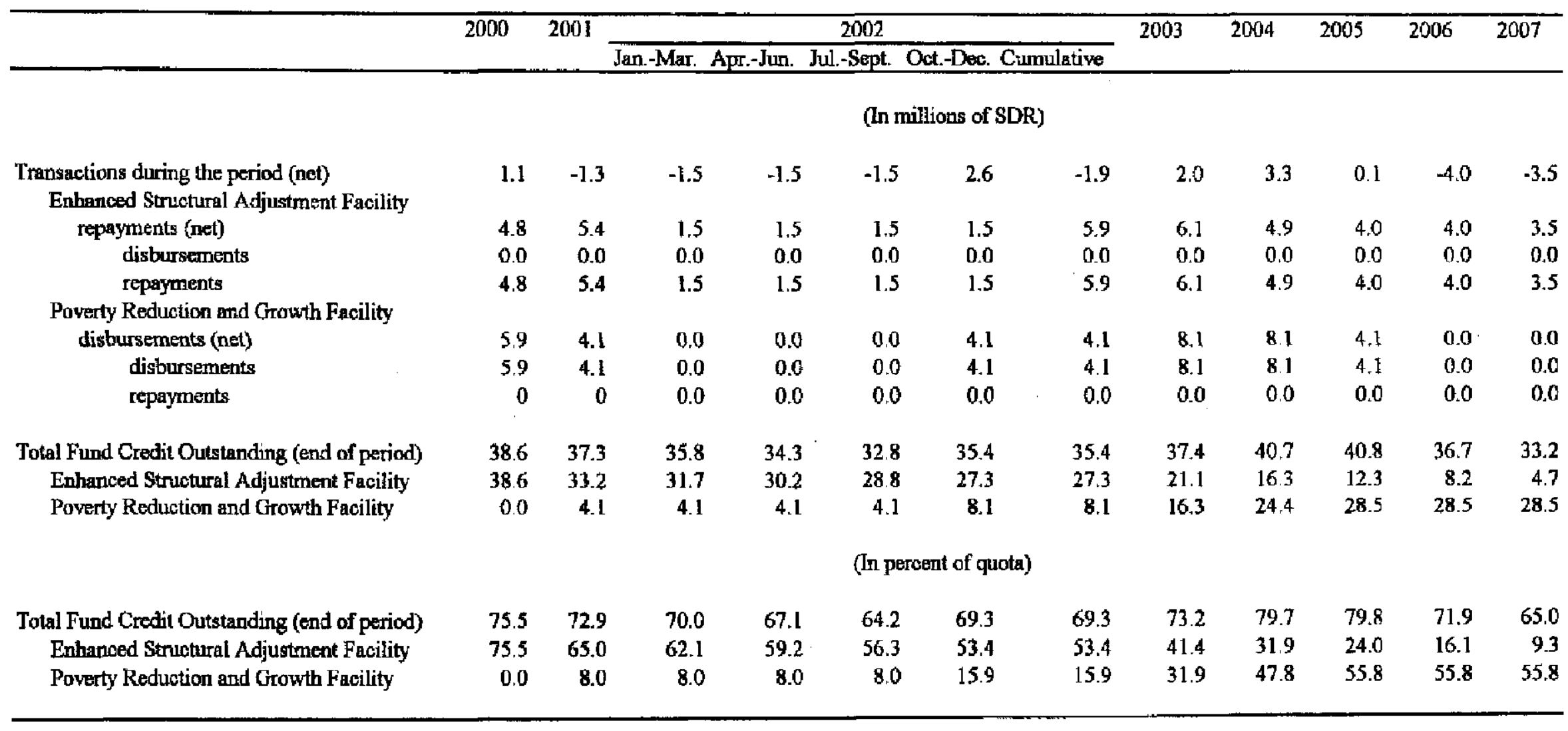

Sources: International Monetary Fund, Treasurer's Department , and staff projections.

I/ Assumes disbursements and debt service under the prospective PROF arrangement. 
Figure 1. Mongolia: Economic Developments, 1996-2004 1/
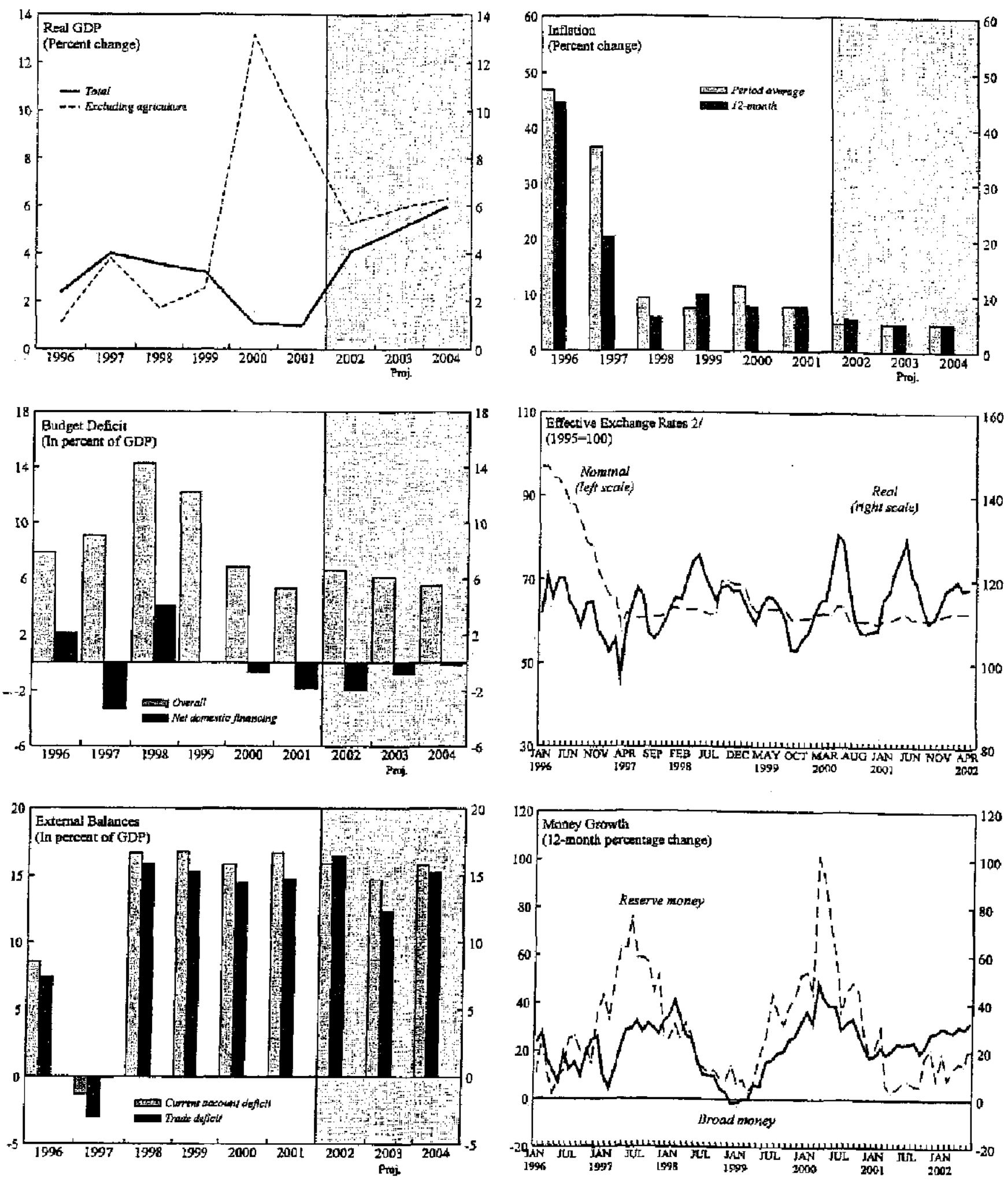

Sourcis: Mongolian authonitieg; and Fund staff estimates.

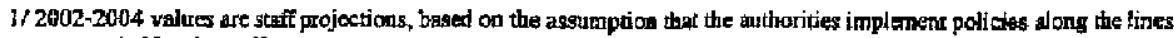
fecomitutanded by the staff.

2T Ag increase indicates apprecistion. 
Figure 2. Mongolia: Fiscal Indicators, 1996-2004

(In percent of GDP)
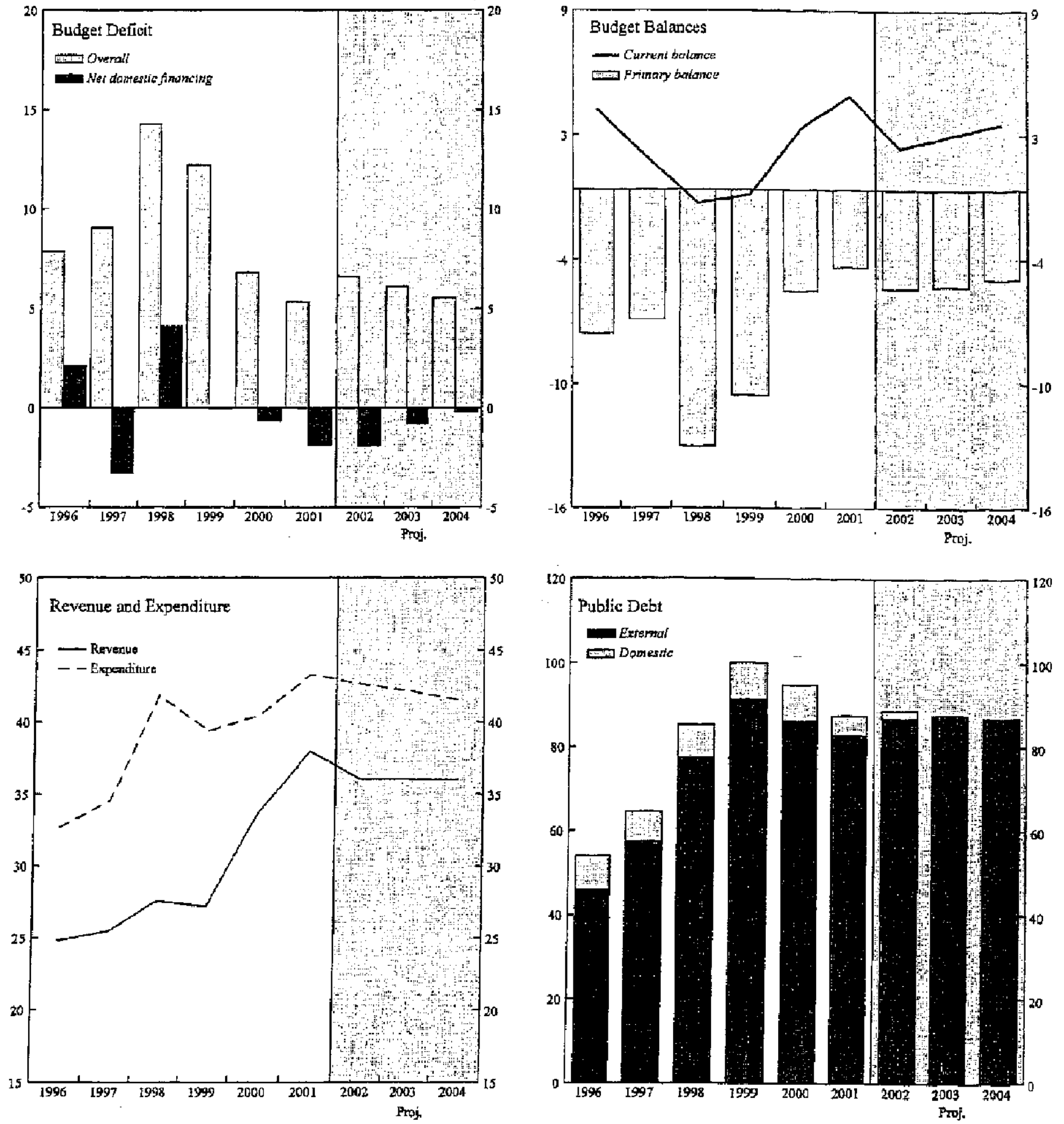

Sources: Mougolian authorities; and Fund staff estimates and projections. 
Figure 3. Mongotia: Monetary Developments, 1996-2002
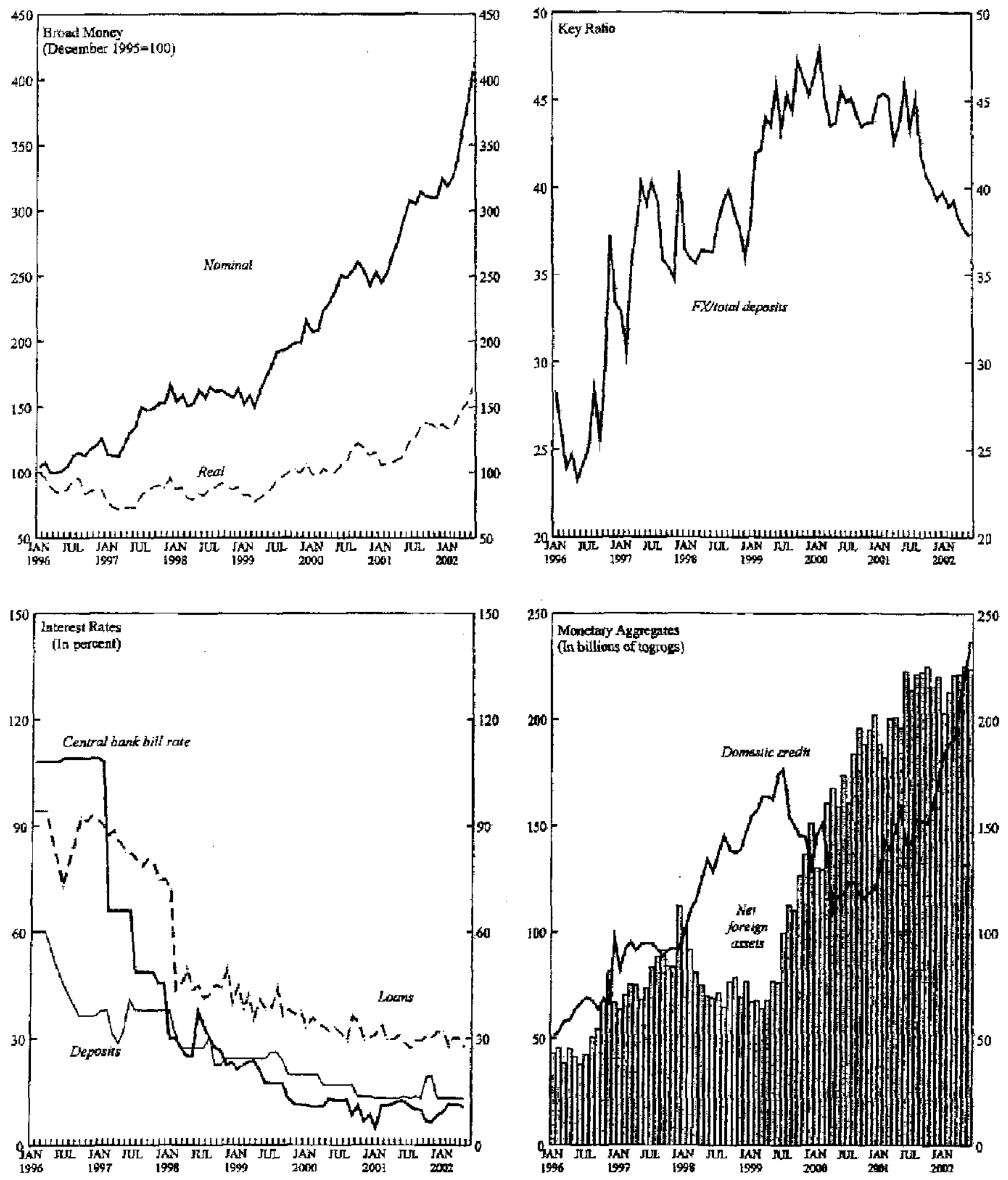

Seurces; Mongolias autbocities; and Fund sreff estimates. 
Figure 4. Mongolia: External Developments, 1996-2004
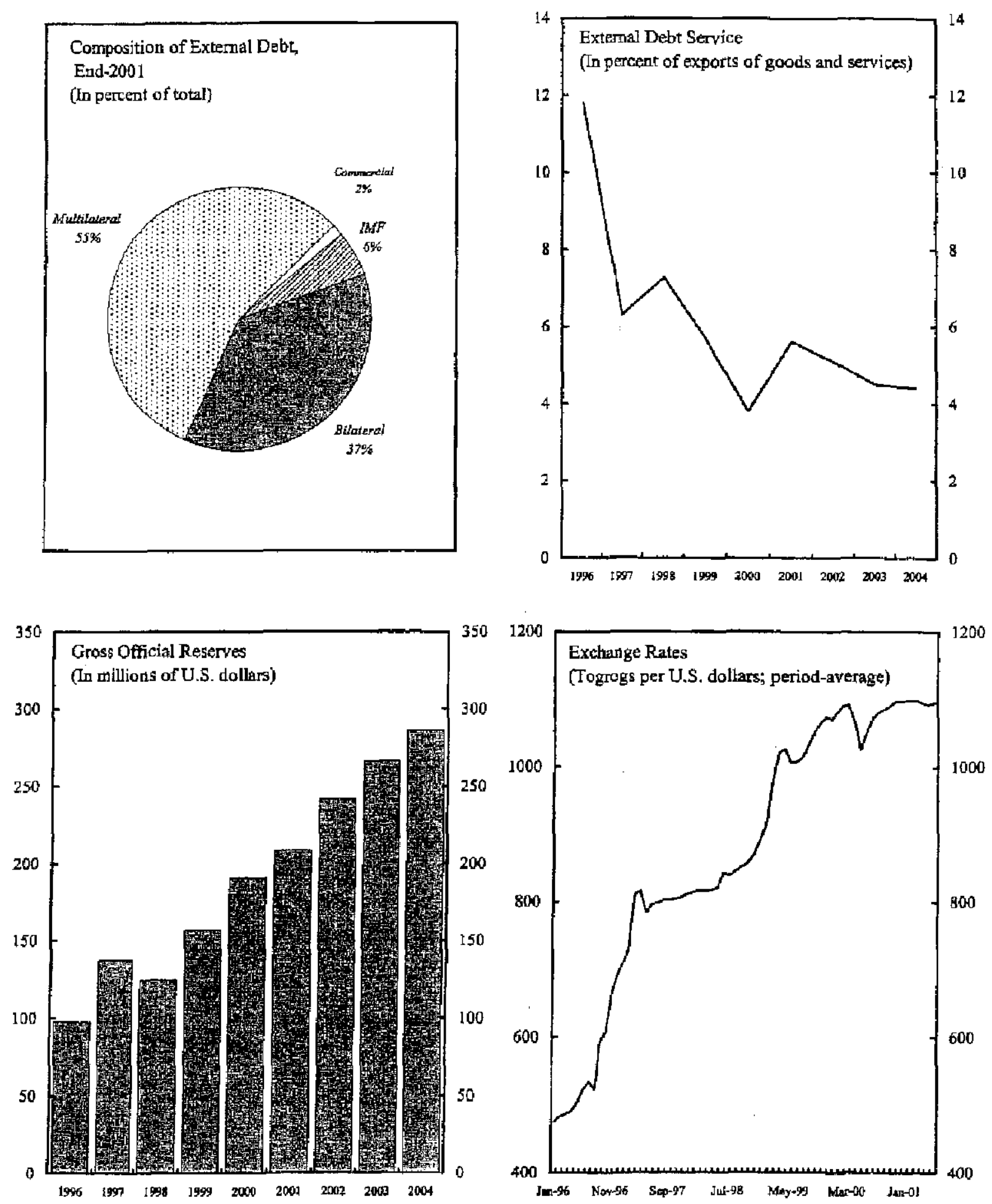

Sources: Mongolian authorities, Fund staff estimates; and International Financial Statistics: IMF. 


\section{Mongolia-Poverty Profile}

According to the 2002 World Development Indicators, the per capita PPP Gross National Income (GNI) in Mongolia was around US\$1,760 in 2000 and was ranked $161^{\text {st }}$ among 207 nations. In light of an average per-capita PPP GNI of US\$1,980 in all low-income countries, Mongolia has one of the lowest living standards in the world.

Statistical data on poverty in Mongolia need to be improved significantly in order to obtain comparable and current estimates of poverty measures. The Living Standards Measurement Surveys (LSMS) conducted in 1995 and 1998, with the assistance of the World Bank and the United Nations Development Program (UNDP) respectively, are the most reliable sources of quantitative data on poverty available. Based on these sources, the salient trends in Mongolia's poverty profile can be summarized as follows. ${ }^{1}$

- The number of people living below the poverty line remained relatively unchanged from 1995-98, after having risen significantly during the early 1990s. Following a sharp increase from a virtual absence of officially recorded poverty prior to the early 1990 s, the poverty rate stabilized at around 35-36 percent during the second half of the decade.

- However, the depth and severty of poverty increased over the period 1995-98, as did income inequality. The depth and severity of poverty rose during the second half of the $1990 \mathrm{~s}$, indicating a widening of the gap between average consumption expenditures of the poor and the poverty line, and a decline in the purchasing power of the poor to acquire basic needs. Incorne inequality worsened, as evidenced by an increase of the Gini coefficient from 0.31 in 1995 to 0.35 in 1998 , but still remains modest by international standards.

- The incidence of poverty is higher in urban centers relative to rural areas. The overall poverty headcount was higher in the aimag (province) centers as was the depth and severity of poverty. This is likely partly a symptom of the lack of economic opportunities in rural areas, and the resultant migration from rural to urban.

- The incidence of poverty is high among female-headed households and large households regardless of location. In 1998, 47 percent of unban and 36 percent of rural female-headed housebolds (defined as bouseholds with no surviving male partner) were classified as poor compared to 29 percent of urban and 26 percent of rural male-headed households. The same year, 45 percent of poor and

\footnotetext{
'However, there exist problems of direct comparability between some indicators in the two LSMS, as the methodology utilized in each was not entirely consistent.
} 
55 percent of extremely poor ${ }^{2}$ urban households were large households (defined as households with six or more members), while the corresponding figures for the rural areas were 51 and 49 percent.

- Labor market status and educational achievement are important determinants of poverty. In 1998, 57 percent of the unemployed lived below the poverty line, while 60 percent of the working age population without a secondary education were classified as poor compared to 18 percent with tertiary or vocational training.

The Participatory Living Standards Assessment (PLSA) 2000 indicates that the gap between the wealthy and the impoverished is perceived to have widened signifienntly over the period 1995-2000. The PLSA was conducted in 2000 by the National Statistical Office of Mongolia (NSO), with assistance from the World Bank and other international agencies, and is a qualitative assessment of poverty in Mongolia. The PLSA indicates that people's perceptions are that new categories of "wealthy" and "impoverished" emerged during the period 1992-95 compared to the relatively low income inequality prevalent prior to 1992 , and that the gap between the rich and the poor intensified over the period 1995-2000.

The PLSA indicates that multiple sources of insecurity and vulnerability emerged in the 1990s. The privatization of state-owned enterprises and pastoral collectives, and the subsequent loss of an assured income from formal employment in the public sector, Ied people to engage in informal sector production and employment, livelihoods particularly vulnerable to seasonal variation. The decline in public action to reduce risks associated with the animal husbandry sector shifted the burden of pastoral risk management from the state to individuals and heightened vulnerability to inclement weather. As a result, two common triggers of impoverishment identified in the PLSA were unemployment in the urban centers, and in rural areas, the loss of livestock due to adverse weather. The cost of education and the unexpected illness of a household member and the associated cost of medical treatment were also identified as significant impoverishment triggers common across both urban and rural areas.

Other social indicators point to a deterioration in social conditions during the $1990 \mathrm{~s}$. In particular, secondary school enrollment rates declined in the 1990 s and infant mortality worsened during the latter half of the decade. The Human Development Index for Mongolia decreased from 0.669 in 1995 to 0.628 in 1998, relegating the country from a rank of 101 in 1995 to 117 in 1998 from among 174 countries. However, most social indicators, in particular, school enrollment and maternal and infant mortality rates, have demonstrated a marked improvement since 1999.

\footnotetext{
${ }^{2}$ Persons with income lower than 40 percent of the minimum living standard are classified as "extremely poor".
} 
The government's I-PRSP articulates a private sector-led growth strategy within the framework of a medium-term macroeconomic stabilization program as the main impetus behind the alleviation of poverty in Mongolia. The government's target is at least a halving of the number of households living below the poverty line and at least a 25 percent reduction in the number of extremely poor households by 2005 , with further inroads by 2015. 
Mongolia-Social and Demographic Indicators

\begin{tabular}{|c|c|c|c|c|c|c|}
\hline \multirow[t]{2}{*}{ Indicator } & \multirow[t]{2}{*}{ Unit of Measure } & \multicolumn{3}{|c|}{ Latest Single Available Year } & \multicolumn{2}{|c|}{ Snne Region/Lucome Group } \\
\hline & & $1980-89$ & 1990-95 & 1996-2001 & $\begin{array}{l}\text { East Asia } \\
\& \text { PaciJic } \\
\end{array}$ & $\begin{array}{l}\text { Low- } \\
\text { iacome }\end{array}$ \\
\hline \multicolumn{7}{|l|}{ Poverty } \\
\hline National headcount index & Percent of population & $\ldots$ & 36.3 & 35.6 & $\ldots$ & $\cdots$ \\
\hline Utban headcoutunt index & Percent of population & $\ldots$ & 38.5 & 39.4 & $\cdots$ & $\ldots$ \\
\hline Rurral headcount index & Percent of population & $\ldots$ & 33.1 & 32.6 & $\ldots$ & '.. \\
\hline \multicolumn{7}{|l|}{ Income } \\
\hline GDP per capita & Constatat 1995 USS & 511 & 392 & 428 & 1,252 & 466 \\
\hline PPP GNI per cayits & PPP intertational dollars & 1,750 & 1,540 & 1,760 & 4,130 & 1,980 \\
\hline Gini coefficient & & ... & 0.31 & 0.35 & $\cdots$ & $\cdots$ \\
\hline \multicolumn{7}{|l|}{ Healt th } \\
\hline \multicolumn{7}{|l|}{ Morialin } \\
\hline Infant mortality & Per 1,000 live births & $\ldots$ & 44.4 & 30.0 & 35.5 & 76.1 \\
\hline Matemal mortality & Per 100,000 live birtins & $\ldots$ & 101.0 & 82.0 & $\ldots$ & $\ldots$ \\
\hline \multicolumn{7}{|l|}{ Immitenization rafe } \\
\hline Measles & Percent under 12 -manthis & 86.0 & 85.0 & 93.0 & 85.4 & 56.6 \\
\hline DPT & Percent under :2-months & 84.0 & 88.0 & 94.0 & 85.2 & 56.6 \\
\hline Child malnucrition & Weight for age, percent under five years & $\ldots$ & 12.3 & 8.6 & $\mathbf{L} 0.0$ & $\cdots$ \\
\hline \multicolumn{7}{|l|}{ Life expecrancy as birth } \\
\hline Total & Years & 61 & 65 & 67 & 69 & 59 \\
\hline Male & Years & 60 & 64 & 65 & 67 & 38 \\
\hline Female & Years & 63 & 66 & 69 & 71 & 60 \\
\hline Actess to water supply & Percent of population & $\ldots$ & 67.5 & 51.9 & 74.8 & 75.7 \\
\hline Population per physician & Persons & $\ldots$ & 393 & 368 & 909 & 1,667 \\
\hline Population per nurse & Fersons & $\ldots$ & 279 & 324 & $\ldots$ & $\ldots$ \\
\hline Fopulation per hospiral bed & Persons & m. & 100 & 133 & 333 & 667 \\
\hline \multicolumn{7}{|l|}{ Education } \\
\hline \multicolumn{7}{|l|}{ Gross enrollment rates } \\
\hline \multicolumn{7}{|l|}{ Prinary } \\
\hline Totat & Percent of age group & $\ldots$ & 93.4 & 102.1 & 119.4 & 96.6 \\
\hline Male & Percenk of age group & $\ldots$ & 93.6 & 101.5 & 120.9 & 102.5 \\
\hline Female & Pescertu of age groulp & $\cdots$ & 93.1 & 102.6 & 120.9 & 85.5 \\
\hline Secondary & Percent of age group & $\ldots$ & 65.6 & 68.2 & 68.9 & 45.7 \\
\hline Pupil-teacher ralio: primary & Pupjils per teachar & 30.9 & 24.8 & 30.9 & 23.0 & 42.0 \\
\hline \multicolumn{7}{|l|}{ Adull Witeracy } \\
\hline Total & Percent of population aged $15+$ & 48.2 & 41.7 & 39.6 & 14.2 & 37.6 \\
\hline Male & Percent of males aged $55+$ & 35.6 & 30.5 & 28,1 & 7,9 & 28.4 \\
\hline Fenale & Percert of females aged $15+$ & 60.5 & 52.7 & 49.0 & 20.7 & 47.0 \\
\hline \multicolumn{7}{|l|}{ Hurann Resources } \\
\hline \multicolumn{7}{|l|}{ Population } \\
\hline Total & Millions, mid-ycar & 2.1 & 2.3 & 2.4 & $1,855.2$ & $2,459.8$ \\
\hline Uiban & Percent of poptlation & $\$ 67$ & $\$ 2.3$ & 57.6 & 35.2 & 31.9 \\
\hline \multicolumn{7}{|l|}{ Population growth rave } \\
\hline Total & Anntal Percent & 2.4 & 1.5 & 1.3 & 1.1 & 1.9 \\
\hline Urban & Annual Percem & 6.0 & -1.7 & -1.0 & .r & 3.4 \\
\hline \multicolumn{7}{|l|}{ Labor force (aged $15-64$ ) } \\
\hline Total & Millions. & $\ldots$ & 0.8[ & 0.85 & $1,051.70$ & $1,115.07$ \\
\hline Female & Percent of labor force & $\ldots$ & 47.3 & 48.7 & 44.4 & 37.8 \\
\hline Age dependency ratio & Dep. to working-age pop. & 0.84 & 0.74 & 0.63 & 0.50 & 0.71 \\
\hline Fettility rate & Births per woman & 4.8 & 3.6 & 2.5 & 2.1 & 3.6 \\
\hline Natural Resources & & & & & & \\
\hline Land area & Thoostand, sq. kan & $1,566.5$ & $1,566.5$ & 1566.5 & $15,968.9$ & $32,535.7$ \\
\hline Population Densily & Persons per sq. km & 1.32 & 1.45 & 1.53 & 116.17 & 75.60 \\
\hline Arable land & Percent of land area & 0.88 & 6.84 & 0.84 & 11.85 & 13.17 \\
\hline Irrigrated land & Percent of crop land & 5.6 & 6.4 & 6.4 & 38.7 & 26.4 \\
\hline
\end{tabular}

Sources: Word Bank: World Development Indicators Database, National Statistical Office of Mongolia (NSO), UNDP and NSO:

Living Siandard Measurement Sunvey (1998) and sthff estimates. 


\section{Mongolia-External and Public Debt Sustainability Analysis}

1. To evaluate Mongolia's external and public debt sustainability, this note examines the evolution of critical debt indicators under various scenarios for the key underlying variables and assesses the sensitivity of debt dynamics to a number of standardized shocks in the context of the debt sustainability framework recently developed in the Fund (SM/02/166).

\section{A. The Structure of Mongolia's External Public Debt}

2. In discussing the structure of Mongolia's external public debt, a major distinction needs to be drawn between the debts incurred before and after the transition in 1991. Pre1991 debt, denominated largely in transferable rubles (TR), arose primarily as a result of Mongolia's transactions with the former Soviet Union. While the amount of this debt is very large in nominal terms (equivalent to about ten times Mongolia's annual GDP), the terms for its settlement have not yet been agreed, and it is not currently being serviced ${ }^{1}$ Post-1991 debt, by contrast, includes mainly debts to official creditors, which are denominated in freely convertible currencies, carry well-defined interest rates and maturity terms, and are being regularly serviced.

3. Pending a settlement on the large stock of pre-1991 transferable ruble debt, the staff's analysis in recent years has focused mainiy on post-1991 debt. As of end-2001, total post1991 public and publicly guaranteed debt amounted to US\$853 million (83 percent of GDP), of which 61.3 percent was owed to multilateral institutions, 37.1 percent to bilateral

creditors, and only 1.5 percent to commercial creditors. As most official debt comprises longterm loans with concessional interest rates, Mongolia's annual debt service burden is very low, currently at 3.3 percent of GDP. The net present value (NPV) of the total post-1991 debt amounted to US\$572 million (67 percent of nominal value or $551 / 2$ percent of GDP) as of end-2001.

4. Following the recent staff practice, the analysis in Sections B, C and D below focuses on assessing the sustainability of post-1991 debt, excluding the transferable ruble claims held by Russia. Section B reviews the staff's baseline scenario, which is the benchmark for the subsequent sensitivity analysis, while Sections $C$ and $D$ include separate presentations on the stress tests that have been conducted to assess, respectively, the sustainability of external debt and public debt. A separate sensitivity test is conducted in Section E to illustrate how the eventual settlement on transferable nuble debt might affect Mongolia's debt dynamics.

\footnotetext{
${ }^{1}$ Based on the data submitted on September 17, 1997 by Russia when it was in the process of joining the Paris Club as a creditor, the total stock of debt disbursed to Mongolia before January 1992 was U\$ $\$ 10,514.7$ million or TR 10,511.5 million. About one third of this debt arose from the clearing of Mongolia's pre-1991 trade deficits with the former Soviet Union, while the bulk of the remainder was related to social infrastructure projects.
} 


\section{B. The Baseline Scenario}

5. The baseline scenario is predicated on the pursuit of prudent macroeconomic policies and steadfast implementation of market-oriented reforms along the lines envisaged in the staff's medium-term macroeconomic framework. In particular, a restrained policy on public expenditures leads to a progressive reduction in the government's primary deficit from 5 percent of GDP in 2002 to 3.2 percent of GDP by 2007 ; monetary and exchange rate policies remain geared to the attainment of the government's disinflation and external reserve objectives; and external debt management remains prudent, with the govermment continuing to borrow primarily on concessional terms while avoiding the issuance of public guarantees for external borrowing by the nongovernment sector. Assuming that these policies are complemented by market-friendly structural reforms, increased private investment along with continuing improvements in economic efficiency helps raise the annual rate of growth of GDP to 5 percent in 2003 and 6 percent thereafter.

6. The baseline scenario implies that both total public debt and external debt are placed on a steadily declining path. The stock of public debt edges up to about 89 percent of GDP in 2002 and it declines steadily thereafter, falling to 78 percent of GDP by 2007. Following a similar pattem, the stock of total external debt (which consists of government and government-guaranteed debt) peaks at a little less than 88 percent of GDP in 2003, and declines to less than 78 percent of GDP by 2007 . With fiscal adjustment allowing Mongolia to gradually retire the outstanding stock of domestic public debt, this scenario implies an improving composition of public debt over time; by 2007, almost all of Mongolia's public debt comprises external debt secured on concessional terms. As a result, debt service payments decline to $2 \frac{1}{2}$ percent of exports of goods and services by 2007 , while the net present value (NPV) of total public debt falls to about 51 percent of GDP.

\section{External Sustainability}

7. Stress tests suggest that, with policies along the lines described above, Mongolia's ratio of external debt to GDP would remain on a downward trend over the medium term irrespective of the nature of the shock, although the level of debt could be much higher in the short run (Table 1). The highlights of the results are as follows:

- A depreciation shock that leads to a 30 percent decline in the GDP deflator (stress test 7) would have by far the most severe impact; the ratio of external debt to GDP would peak at 124 percent in 2002, and it would still exceed 100 percent by 2007 . A shock on the U.S. dollar-based GDP deflator (stress test 4) would cause a similar, although somewhat attenuated, spike in the debt ratio. These results underscore the importance of maintaining a flexible exchange rate regime to avoid any misalignment that might necessitate a sharp adjustment down the road.

- Noninterest current account shocks (stress tests 5 and 6) could also cause a sharp increase in the debt stock; the extemal debt ratio would peak at 103-103.5 percent of GDP in 2003, but it would fall to less than 90 percent by 2007 . These tests highlight 
the vulnerability of Mongolia's debt dynamics to terms of trade shocks, which remain subject to sharp fluctuations given its relatively narrow commodity export base.

- A real GDP growth rate shock (stress test 3) would have a significant but more moderate effect on the external debt ratio, which would peak at about 96 percent of GDP in 2003, and would decline to 84 percent of GDP by 2007.

- Not surprisingly, given the concessionality of Mongolia's external debt, an interest rate shock (stress test 2) would have a marginal impact on the level of debt even in the short run.

- Finally, under the scenario with average historical values of key variables (stress test 1), the debt ratio would decline faster than under the baseline scenario. While the bistorical average GDP growth rate was lower than the growth envisaged in the baseline scenario, the effect of this is more than offset by a smaller current account deficit and a more favorable path for the U.S. dollar-based GDP deflator.

\section{Fiscal Sustainability}

8. The sensitivity analysis on fiscal sustainabllity serves to highlight that policy slippages pose by far the principal risk for Mongolia's public debt dynamics (Table 2). In contrast to the external sustainability analysis, which was predicated on the maintenance of sound macroeconomic policies, the fiscal sustainability analysis includes slippage scenarios which would allow the primary fiscal deficit to be significantly larger than in the baseline scenario. The stress tests suggest that such policy slippages would be of far more consequence than any of the external shocks considered above. The highlights of the results are as follows:

- A reversion of the key parameters to the average levels recorded over the last few years would lead to a continuing increase in the ratio of debt-to-GDP, which would rise from $92 \frac{1}{2}$ percent in 2002 to 107 percent by 2007 (stress test 1 ). While none of the nonpolicy parameters alone can account for the unsustainable path of public debt, any combination of historical averages that includes the average primary deficit of recent years ( $7^{1 / 2}$ percent of GDP) proves unsustainable. Enduring fiscal consolidation therefore is indispensable for debt sustainability.

- Even with only a temporary increase of the primary deficit, the public debt ratio would remain at well over 100 percent over the medium term and, by 2007 , it would still be at a level of around 90 percent (stress tests 4 and 5). Given Mongolia's exposure to harsh winters and its heavy reliance on revenues from trade-almost 45 percent of tax revenues are trade-related-its primary deficit remains subject to substantial volatility. This reinforces the need for a strong effort to curb expenditure growtb. 
As in the case of external debt dynamics, a one-time 30 percent depreciation causes a sharp increase in the public debt ratio in 2002 (stress test 6); while that ratio declines steadily thereafter, it is still well over 90 percent by 2007 .

Shocks on the interest rate or the real GDP growth rate or the debt ratio alone do not appear to pose any major threat to fiscal sustainability (stress tests 2,3 and 7); in each of these cases, following an initial jump in the level of public debt, the ratio of public debt to GDP declines steadily and falls to less than 85 percent by 2007 . However, owing to the substantial share of high-interest domestic debt in the past, an interest shock based on historical averages (stress test 2) leads to a much higher deviation of the public debt ratio from the baseline than in the external debt sustainability analysis.

\section{E. Implications of Settlement of Transferable Rable Claims}

9. The terms of settlement of the transferable ruble debt to Russia are an important source of uncertainty for Mongolia's debt sustainability. Mongolia and Russia bave recently initiated a round of discussions on this matter through the Intergovernmental Commission on Bilateral Economic Relations. While no agreement on the ultimate size or method of settlement has been reached, both parties agreed on the principle that this matter should be resolved through bilateral negotiations in a way compatible with Mongolia's debt sustainability and fiscal constraints.

10. To illustrate how the terms of such a settlement might affect the baseline scenario, the staff has conducted a test under hypothetical up-front discount rates of 70 percent, 80 percent, and 90 percent. ${ }^{2}$ The balance was assumed to be rescheduled with a 20-year maturity, five-year grace period, and a market interest rate of 5.85 percent in U.S. dollars (comparable to the prevailing CIRR). As illustrated in Table 3, Mongolia's public debt ratio could rise to an unsustainable level under either one of the above scenarios. Against this background, Mongolia would need to secure better terms for the restructuring of its debt to Russia and/or approach the Paris Club to request a formal rescheduling on the whole stock of its official debt (including some US\$90 million of public enterprise debt that is not guaranteed by the government). If it were to take the latter course of action, Mongolia could also consider its possible eligibility for relief under the HIPC Initiative depending on the final terms of debt reduction under the Paris Club. In any case, the authorities would need to carefully consider all available options, in consultation with the main creditors, bearing in mind the possible repercussions on future debt service payments and new drawings.

${ }^{2}$ Under the understanding reached between Russia and the Paris Club, transferable ruble debt owed by countries for which Russia is the sole or largest military creditor among Paris Club members could be eligible for 80 percent discount. Among recent precedents, Vietnam settled its debt with Russia in 2000 by obtaining 85 percent reduction of the principal and agreeing to repay the remainder over 23 years at an interest rate of 5 percent $(\mathrm{EBS} / 01 / 43)$, while a 90 percent up-front discount was applied to Nicaragua's debt in 1996 (SM/96/238). 
Table 1. Mongolia : External Sustainability Framework, 1995-2007

\begin{tabular}{|c|c|c|c|c|c|c|c|c|c|c|c|c|c|}
\hline & \multicolumn{7}{|c|}{ Aetralt } & \multicolumn{6}{|c|}{ Projectiens } \\
\hline & 1995 & 1996 & $199 ?$ & 1998 & 199 & 2000 & 2001 & 2002 & 2003 & 2004 & 2006 & 2006 & 2007 \\
\hline \multicolumn{14}{|l|}{ L Basollno Motium-Term Profections } \\
\hline I Exthreal dab:5xports of GASS & 95.6 & 113.2 & 99.6 & 148.6 & 156.3 & 130.8 & $3,34.1$ & 127.9 & 127.6 & 127.5 & 123.9 & 121.7 & 119,4 \\
\hline 2 Extermal debuGDP & $\Delta 1,1$ & 46.0 & 57.4 & 77,4 & 91.4 & 86.3 & 82.9 & 87.0 & 87.7 & 87.0 & 44.6 & 81.3 & J7. \\
\hline 3 Change in extcrnal debthGDP & -32.3 & 4.9 & I 1.4 & 20.7 & 14,0 & -5.1 & -3.4 & $4, i$ & 0.7 & -0.7 & -2.4 & -3.3 & -3.6 \\
\hline 4 Net debt-creating extemal fows/GDP $(5+9+12)$ & .35 .2 & 3.4 & 0.4 & 14.3 & [1.3 & -4.6 & -1.7 & $\mathbf{2 . 6}$ & -3.5 & -4.8 & $-\$ .8$ & -5.6 & +5.1 \\
\hline 5 Cinedt account deficiL excluding interest payments/GDP & -2.9 & 2.3 & -3.9 & 10.3 & 8.6 & 4.7 & 6.6 & 7.3 & 6.0 & 5.0 & 4.0 & 4.1 & 4.2 \\
\hline 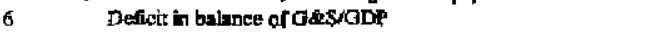 & 23 & 7.9 & 1.7 & 17,0 & 16.1 & 15.3 & 18.7 & 17.6 & 14.1 & 12.5 & 11,0 & 10.5 & 10.1 \\
\hline Exports of GESKGPP & 43.0 & 40,5 & 57.6 & 52,1 & 58.3 & 66.0 & 61.8 & 68 & 68.7 & 68.3 & 60.3 & 66.8 & 65.1 \\
\hline Import of OLS/GDP & 43.2 & 48.6 & 59,4 & 69.1 & 74.6 & B1.3 & $80 . \$$ & 85.6 & 83.0 & 80.7 & 79.2 & 77.3 & 75.2 \\
\hline Minus net non-debt creating capital inflows/GDP & -0.8 & -1.3 & $-1,9$ & -1.9 & -3.8 & -4.1 & $-4,2$ & -5.3 & -4.0 & -3.8 & .3 .7 & -3.5 & $.3,4$ \\
\hline Met forwign direct investment, equity/GDP & 0.8 & $\$ .3$ & 1.9 & 1.9 & 3.8 & 4.1 & 4.2 & 5.3 & 4.0 & 3.8 & 5.7 & 3.5 & 3.4 \\
\hline Net portfolio investulentequity/GDP & 0.0 & 0.0 & 0.0 & 0.0 & 0.0 & 0.0 & 0.0 & 0.0 & 0.0 & 0.0 & 0.0 & 0.0 & 0.0 \\
\hline$(r-g-(\rho+g \rho)) y(1+g+\rho+\alpha \rho)) d e b t K G D P(14 / 13)$ & $. \$ 1,6$ & 2.4 & 6.2 & 5.8 & 6.6 & -5.1 & -4.2 & -4.6 & -3.5 & 6.1 & -6.1 & -6.1 & -5.9 \\
\hline Adjustment finctot: $\mathrm{l}+\mathrm{g}+\mathrm{p}+\mathrm{g} \rho$ & 1.8 & 1.0 & 0.9 & 0.9 & 0.9 & 1.1 & 1.1 & 1.1 & 1,1 & 1.1 & 1.1 & B.1 & 1.1 \\
\hline$(1-g-(\beta+g \rho)) d e b t G D P(15+16+17)$ & -56.4 & 2.4 & $\$, 9$ & 3.3 & 6.1 & -5.5 & -4.4 & $-4,9$ & -6.0 & -6.6 & 6.6 & -6.7 & -6.4 \\
\hline$r$ (imterest rate) times debt/GDP & 3.4 & 0.8 & 0.6 & 0.9 & 0.8 & 1.0 & 0.9 & 1.0 & 1.5 & 1.1 & 1.1 & 1.0 & 1.0 \\
\hline minus g (real GDP growth trite) times debt/GDP & -4.6 & $-1,0$ & -1.9 & $-2,0$ & -2.5 & +1.0 & -1.0 & -3.2 & -4.4 & -5.2 & -5.2 & $-\$ 11$ & -4.9 \\
\hline minus $(\rho+g p)(\rho=$ U.S. doliar value of GDP deflator, grow & -53.1 & 2.6 & 6.7 & 6.5 & 7.8 & -5.5 & -4.4 & -2.7 & -2.7 & -2.5 & -2.5 & -2.6 & -2.5 \\
\hline 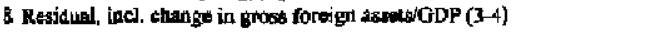 & 2.9 & 1.5 & 10 & 5.9 & 2.6 & -0.5 & -1.7 & 6.7 & 4.2 & 4.2 & 3.4 & 2.3 & 1.4 \\
\hline \multicolumn{14}{|l|}{ Memorandum [tems: Key makro and externe] agewrptions } \\
\hline Nominal GDP (loeal ounoway) & 550.3 & 646.5 & 8326 & 817.4 & 925.3 & $1,044.6$ & $1,130,5$ & $1,245.0$ & $1,373.2$ & $1,528.0$ & $1, \pi 02.2$ & $1,893.2$ & $2,107.3$ \\
\hline Naminal GDP (U.S. dollars) & $1,236.6 !$ & $1,179.0$ & $1,054.0$ & 972.1 & 905.5 & 979.2 & $1,029.9$ & $1,104.0$ & $1,193.7$ & $1,299.3$ & $1,414,6$ & $1,542.9$ & $1,683.1$ \\
\hline Reat GDP gowti (in percent per year) & 6.3 & 2.4 & 4.0 & 3.5 & 3.2 & 3.1 & 1.1 & 3.9 & 5.0 & 60 & 6.1 & 6.0 & 5.0 \\
\hline 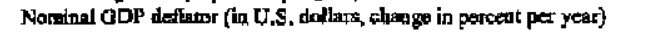 & 68.1 & -6.1 & -14.1 & .10 .9 & -9.8 & 6.0 & 5.4 & 3.2 & 3.0 & 2.7 & 2.7 & 2,9 & 2.9 \\
\hline Extemal injerest rate (pertent per year) & 1.9 & I.B & 1.4 & 15 & 1.0 & 1.1 & 1.1 & 1.3 & 1.3 & 1.3 & 1.2 & 1.2 & 1.2 \\
\hline Grow th of expors of Ges (U.S, dollar terme, in percent per year) & 29.5 & -9.1 & 26.7 & -16.6 & 4.6 & 29.8 & -10.5 & 17.9 & 9.3 & 8.1 & 8.9 & 6.8 & 5.2 \\
\hline Grewth of imports of GSES (U.S. chollar berms, in percont per year) & 30.7 & 3.2 & 93 & 7.4 & 0.5 & 16.8 & 5.1 & 14.0 & 4.9 & 5.9 & 6.9 & 6.4 & 6.1 \\
\hline \multicolumn{14}{|l|}{ D. Sensitivity Annlysti for External Debr-to-GDP Rads } \\
\hline \\
\hline & & basciline & $=$ & & & & & & 84.6 & 44.2 & $\mathbf{2 3 , 0}$ & 80.8 & 77.9 \\
\hline 2 If interest rate in 2002 and 2003 is arcrage plas two standant deviations & s, othas at & ns a g then & Taterelia & & & & & 87.6 & 89.17 & 6 - & t5. 7 & 823 & 786 \\
\hline & & Ins, dowe & & & & & & 94.5 & 95.7 & 94.9 & 10 & 87.8 & $\$ 3.7$ \\
\hline \multirow{3}{*}{\multicolumn{8}{|c|}{ 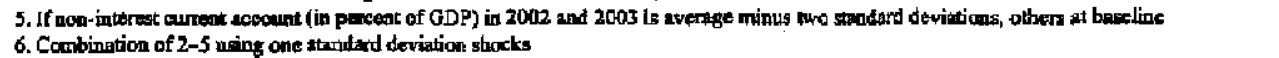 }} & 100.0 & 99.9 & 90.4 & 951 & 91.1 & 66.8 \\
\hline & & & & & & & & 94.2 & 103.0 & 1013 & 97.9 & 93,6 & E9.1 \\
\hline \multirow{2}{*}{\multicolumn{8}{|c|}{ 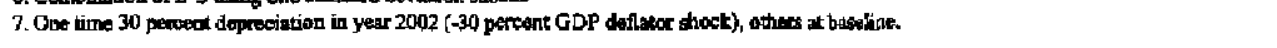 }} & 96.4 & 103.4 & 102.6 & 982 & 93.9 & 89.4 \\
\hline & & & & & & & & 124,1 & 122.4 & 1193 & $1] 4.6$ & I\%9.2 & 103.6 \\
\hline \multicolumn{14}{|l|}{ Memangindurn tegns } \\
\hline \multicolumn{8}{|c|}{ Cument account deficit, thcluding interest payments (percent of GDP, averige of past seven yeans) } & 3.7 & 3.7 & 3.7 & 3.7 & 3.7 & 3.7 \\
\hline \multicolumn{8}{|c|}{ Curent account deficit, excluding intrrest payments (pexcant of GDP, standard devitaiden of past severn years) } & 5.4 & 5.4 & $\mathbf{5 . 4}$ & 5.4 & 5,4 & 3.4 \\
\hline \multicolumn{8}{|l|}{ Net hoh-debt ertating capital infows (pencent of GDP, avarage of past seven ytars) } & 2.6 & 2.6 & 2.6 & 2.6 & 2,6 & 2.6 \\
\hline \multicolumn{8}{|l|}{ Interest rate (overage of past sevea years) } & 1.4 & 1,4 & ].4 & 1.4 & 1,4 & 1.4 \\
\hline \multicolumn{8}{|l|}{ Intrest rate (standiand deviation of past goven yaurs) } & 0.3 & 0.3 & 0.3 & 0.3 & 0.3 & 0.3 \\
\hline \multicolumn{8}{|l|}{ Real GDP growith rate (average of past seven years) } & 3.1 & 3.1 & 3.1 & 3.1 & 3.1 & 3.1 \\
\hline \multicolumn{8}{|l|}{ Real GDP growth rote (stondard deviation of past seven years) } & 1.8 & 1.8 & 1.8 & I.6 & 1.8 & 1.8 \\
\hline \multicolumn{8}{|l|}{ GDP defiztor, US dollar erms (average of past seven years) } & 5.5 & 5.5 & 5.5 & 5.5 & 5.5 & 35 \\
\hline \multicolumn{8}{|l|}{ 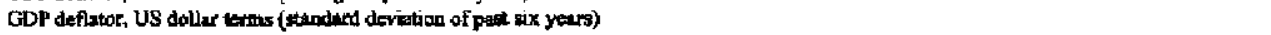 } & 8.5 & 8.5 & 8.5 & 8.5 & 8.5 & 8.5 \\
\hline
\end{tabular}


Table 2. Mongolia: Public Sector Debt Sustainability Framework, 1999-2007

\begin{tabular}{|c|c|c|c|c|c|c|c|c|c|c|c|c|c|}
\hline & \multicolumn{7}{|c|}{ 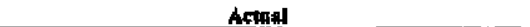 } & \multicolumn{6}{|c|}{ Frojectlons } \\
\hline & 1005 & 1996 & 1997 & 1998 & 1999 & 2300 & 2001 & 2002 & 2003 & 2004 & 2005 & 2006 & 20001 \\
\hline \multicolumn{14}{|l|}{ I. Baneline Medium-Terro Projections I/ } \\
\hline I Public detay'tevensirs & 163.2 & 217.6 & 253.2 & 309.2 & 368.0 & 281.6 & 238.7 & 248.2 & 245.4 & 243.3 & 236.5 & 227.7 & 218,4 \\
\hline \multirow{2}{*}{$\begin{array}{l}\text { 2 Publie deturasp } \\
3 \text { Change in public dets'onP }\end{array}$} & 423 & $\$ 4,0$ & 64.5 & 85.3 & 100.1 & 94.7 & 87.6 & 38.. & 87.9 & 87.0 & $\$ 4.6$ & $\$ 1.4$ & 78.1 \\
\hline & 3 & 11.7 & 10.5 & 20.8 & 14.8 & -5.4 & -7.1 & 1.2 & -1.8 & -0.9 & -2.4 & -3.6 & -3.3 \\
\hline 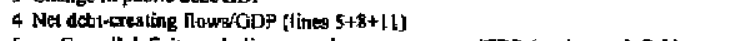 & -29.1 & 1.2 & -4.2 & 13.7 & 1.0 & -5.7 & -3.2 & .3 .0 & -3.1 & -4.0 & -4.4 & .4 .5 & 4.6 \\
\hline 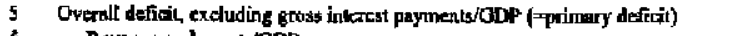 & 5.6 & 7,3 & 6.5 & 12.9 & 10.3 & 5.1 & 3.9 & So & 4.9 & 4.5 & \$.0 & 3.7 & 3.2 \\
\hline Revenut and grantstoon & 25.6 & 24.8 & 25.5 & 27.6 & 27.2 & 331.6 & 38.0 & 358 & 35.8 & 35.8 & 35.8 & 35.8 & 35.8 \\
\hline Noninherest expenditure/ODP & 31.2 & 32.1 & 32.0 & 40.5 & 37.5 & 38.7 & 41.9 & 40.8 & 40.7 & 40.2 & 39.8 & 39.4 & 39.0 \\
\hline 8 Minus non-dot encating filubecing flows/ODP & -0.7 & -0.4 & -1.2 & -1.8 & -1.3 & $.1 . t$ & -1.4 & -1.6 & -1.0 & -0.6 & $\$ 0.6$ & -0.5 & $-0,3$ \\
\hline Privatization Receiplu/GDP & 0.7 & 0.4 & 1.2 & 1.8 & 1.3 & 0.7 & 0.5 & 1.6 & 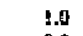 & 0.6 & 0.6 & 0.5 & 0.5 \\
\hline Other & 0.0 & 00 & 0.0 & 0.0 & 0.0 & 0.4 & 0.9 & 0.0 & 0.0 & 0.0 & 0.0 & 0.0 & 0.0 \\
\hline 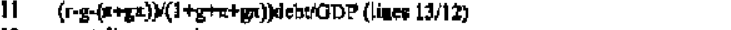 & -33.9 & -5.1 & $-9,5$ & 2.6 & $-B .1$ & -9.7 & 4.7 & -6.4 & -7.0 & -7.9 & -7.8 & -7.7 & -7.4 \\
\hline 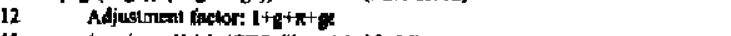 & 1.9 & 1.2 & 1.3 & 1.0 & t.1 & 1.1 & i.1 & 1.1 & i.t & i.t & 1.1 & 1.I & 1.1 \\
\hline$(x-8-(n+8 \pi)) d$ debdoDP (lines $14+15+16)$ & -659 & 6.7 & -12.3 & 2.9 & -9.1 & $-10,9$ & -6.2 & -7.0 & -7.8 & -8.7 & -8.7 & +8.5 & -8.2 \\
\hline$r$ (intere: & 0.6 & 0.7 & $3 \mathbf{3}$ & 1.3 & 2,1 & 2.0 & 1.6 & 1.8 & 1.4 & 1.2 & 1.1 & 1.0 & 1.0 \\
\hline uinus g (res ODP grawth mate) times deb/GDP & -4.5 & -1.0 & -2.2 & -2.3 & -2.7 & -1.1 & -1.1 & -3.4 & .4.5 & -5.2 & -5.2 & -5.1 & - .9 \\
\hline 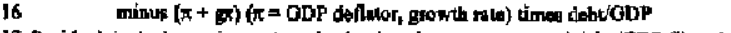 & -62.1 & 6.4 & $-1,3.4$ & 3,5 & -8.5 & -11.8 & -6.7 & -5.4 & -4.7 & -4.7 & -4.6 & - A.5 & -4.3 \\
\hline 17 Reridual, incl, change in asseds and valuation changes on extcmal debt/GDP (lines: & 0.7 & 10.5 & 14.7 & 7.1 & 13.8 & 0.3 & -3.9 & 4.2 & 2.2 & 3.1 & 1.9 & 1.3 & 13 \\
\hline \multicolumn{14}{|l|}{ Memorendupl hoon: Kex ancro and entenal assumptions } \\
\hline \multirow{7}{*}{ 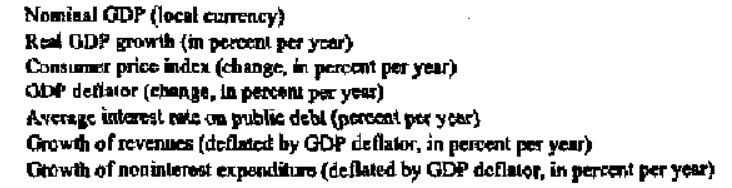 } & 350.3 & 646,6 & 832.6 & 817.4 & 925.3 & $1,044,6$ & $1,130.5$ & $1,245.0$ & $1,373.2$ & $1,528.0$ & 1,7002 & 8993.2 & $2,107.1$ \\
\hline & 6.3 & 2.4 & 4.0 & 3.5 & 3.2 & 1.1 & 1.1 & 3.9 & 5.0 & 5.0 & 60 & 6.0 & 6.0 \\
\hline & 56.8 & 46.8 & 36.6 & 9.4 & 7.6 & 11.6 & 8.0 & 6.0 & 5.0 & 5.0 & 5.0 & 5.0 & 5.0 \\
\hline & $8 \geq 7$ & 14.8 & 23.8 & -5.2 & 9.7 & $\$ 1.7$ & 7.0 & 6.0 & 5.0 & 50 & 5.0 & 5.0 & 5.0 \\
\hline & 0.9 & 1.7 & 6.1 & 2.1 & 2.5 & 20 & 1.7 & 2.1 & 1.6 & 1.3 & 1.3 & 1.2 & 1.2 \\
\hline & -10.0 & -0.8 & 6.8 & 12.1 & 1.8 & 25.0 & 14.2 & -2.1 & 5.1 & 5.9 & 6.0 & 6.0 & 6.0 \\
\hline & -17.0 & 5.3 & 3.8 & 310 & -4.4 & 4.3 & 9.3 & 1.2 & 4.8 & 4.9 & 4.8 & 3.1 & $\mathbf{4 . 8}$ \\
\hline \multicolumn{14}{|l|}{ IL Stress Tests } \\
\hline \multirow{2}{*}{\multicolumn{8}{|c|}{ 1. If interest rate, real GDP growithe rate, primary balance and aon-debt flows (in percent of GDP) }} & & & & & & \\
\hline & & & & & & & & 92.6 & 96.0 & 100.2 & 102.9 & 105.0 & 1069 \\
\hline \multirow{2}{*}{\multicolumn{8}{|c|}{ 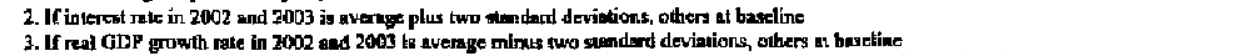 }} & 91.8 & $\begin{array}{l}9.1 .1 \\
9.6 .0\end{array}$ & $\begin{array}{l}92.7 \\
9.4\end{array}$ & 89.7 & $\begin{array}{l}86.1 \\
87.6\end{array}$ & $\begin{array}{l}\text { 82.4. } \\
\text { 89.7 }\end{array}$ \\
\hline & \multirow{2}{*}{\multicolumn{4}{|c|}{ 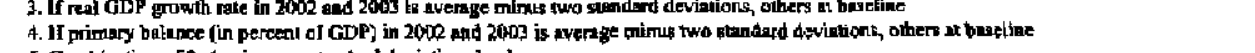 }} & & & & 92.5 & tod.t. & 102.4 & 98.6 & 94.1 & 89.7 \\
\hline \multicolumn{7}{|l|}{ 5. Combination of 2-4 using dine zlendend devistion ahocks } & & 98.2 & 107.9 & 105.2 & 101.2 & 96.5 & 91.8 \\
\hline \multirow{2}{*}{\multicolumn{8}{|c|}{ 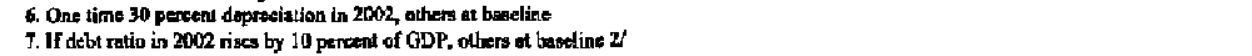 }} & 133.7 & 110.8 & 107. & 103.6 & 98.7 & 93.2 \\
\hline & & & & & & & & 9.8 & 97.1 & 95.4 & 92.1 & Aast & 84.4 \\
\hline \multicolumn{14}{|l|}{ Memonusdunderag } \\
\hline \multicolumn{8}{|l|}{ 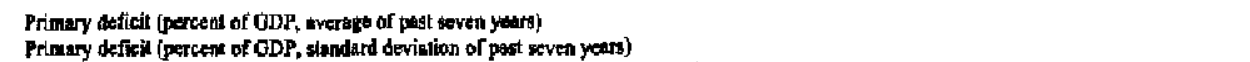 } & 7.4 & 7.4 & 7,4 & 7.4 & $T .4$ & 7.4 \\
\hline \multirow{2}{*}{\multicolumn{8}{|c|}{ Primary defikil (percene of ODP, slandard devinion of past seven years) }} & 3.2 & 3.2 & 3.2 & 3.2 & 3.2 & 3.2 \\
\hline \multirow{2}{*}{\multicolumn{8}{|c|}{ 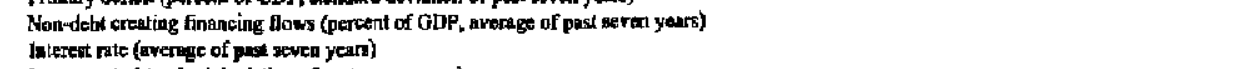 }} & 1.1 & 1,1 & 1.1 & 1.1 & 1.1 & 1.1 \\
\hline & & & & & & & & 2.4 & 2.4 & 2.4 & 2.4 & 2.1 & 2.4 \\
\hline \multicolumn{8}{|l|}{ 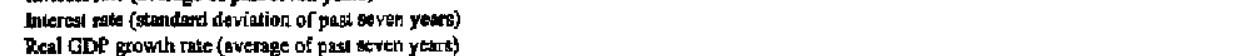 } & 1.7 & 1.7 & 1.7 & 1.7 & 1.7 & 1.7 \\
\hline \multirow{2}{*}{\multicolumn{8}{|c|}{ 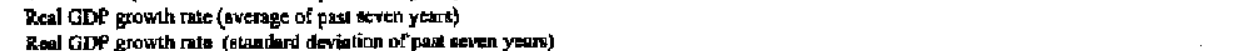 }} & 3.1 & 3.1 & 3.1 & 3.1 & 3.1 & $3+1$ \\
\hline & & & & & & & & 1.8 & 1.8 & 1.8 & 1.8 & $1, \mathrm{R}$ & 1.8 \\
\hline
\end{tabular}

1/ Caleutations caver the genescal gaverwinent.

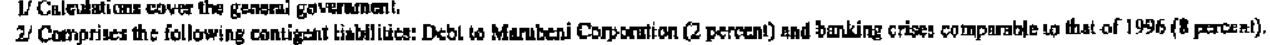


Table 3. Mongolia: Debt Dynamics with Hypothetical Settlement of Russian Claim l/

\begin{tabular}{|c|c|c|c|c|c|c|c|}
\hline Year & 2001 & 2002 & 2003 & 2004 & 2005 & 2006 & 2007 \\
\hline \multicolumn{8}{|l|}{ 1. Base Case } \\
\hline Nomional Debt/ GDP ratio & 82.9 & 87.0 & 87.7 & 87.0 & 84.6 & 81.3 & 77.7 \\
\hline NPV of Debt to Exports Ratio & 93.6 & 93.2 & 919 & 88.6 & 86.2 & 84.3 & 82.7 \\
\hline NPV of Debt to Govermment Revenue Ratio & 146.0 & 159.4 & 158.2 & 156.0 & 151.7 & 146.7 & 141.5 \\
\hline Debt Service to Exports Ratio & 5.5 & 5.2 & 4.6 & 4.4 & 4.4 & 4.3 & 4.3 \\
\hline Debt Service to Government Revenue Ratio & 8.7 & 8.9 & 8.0 & 7.8 & 7.8 & 7.4 & 7.3 \\
\hline \multicolumn{8}{|l|}{ 2. Base Case+ Russian with 70 percent discougt } \\
\hline Nomional Debt/GDP Ratio & 82.9 & 372.7 & 351.9 & 329.8 & 307.6 & 285.8 & 252.6 \\
\hline MPV of Debt to Exports Ratio & 93.6 & 560.0 & $\$ 20.5$ & 473.6 & 4403 & 412.5 & 368.4 \\
\hline NPV of Debt to Government Revenue Ratio & 146.0 & 957.5 & 896.4 & 834.1 & 774.6 & 717.8 & 630.1 \\
\hline Debt Service to Exports Ratio & 5.5 & 5.2 & 29.7 & 26.9 & 25.1 & 23.5 & 42.6 \\
\hline Debt Service to Govemment Revenue Ratio & 8.7 & 8.9 & 51.2 & 47.4 & 44.2 & 40.8 & 72.8 \\
\hline \multicolumn{8}{|l|}{ 3. Base Case+ Russian with 80 percent Discount } \\
\hline Nomional Debt/ GDP ratio & 82.9 & 277.5 & 263.9 & 248.9 & 233.2 & 217.6 & 194.3 \\
\hline NPV of Debt to Exports Ratio & 93.6 & 404.4 & 377.7 & 345.3 & 322.3 & 303.1 & 273.2 \\
\hline NPV of Debt to Government Revenue Ratio & 146.0 & 691.5 & 650.3 & 608.1 & 566.9 & 527,4 & 467.2 \\
\hline Debt Service to Exports Ratio & 5.5 & 5.2 & 21.4 & 19.4 & 18.2 & 17.1 & 29.8 \\
\hline Debt Service to Govemment RevenuesRatio & 8.7 & 8.9 & 36.8 & 34.2 & 32.1 & 29.7 & 51.0 \\
\hline 4. Base Case+ Russian with 90 percent Discount & ! & & & & & & \\
\hline Nomional Debt/ GDP ratio & 82.9 & 182.2 & 175.8 & 167.9 & 158.9 & 149.5 & 136.0 \\
\hline NPV of Debt to Exports Ratio & 93.6 & 248.8 & 234.8 & 216.9 & 204.2 & 193.7 & 178.0 \\
\hline NPV of Debt to Government Revenus Ratio & 146.0 & 425.4 & 404.3 & 382.0 & 359.3 & 337.1 & 304.4 \\
\hline Debt Service to Exports Ratio & 5.5 & 5.2 & 13.0 & 11.9 & 11.3 & 10.7 & 17.0 \\
\hline Debt Service to Government Revenue Ratio & 8.7 & 8.9 & 22.4 & 21.0 & 19.9 & 18.5 & 29.1 \\
\hline
\end{tabular}

l/ It is assumed that Russian claim is settled at the end of 2002, with the first interest payment at the end of 2003 . 


\section{Mongolia-Statistical Issues}

\section{Progress to Date}

The Mongolian authorities have established a framework for monitoring macroeconomic developments and have made substantial improvements in all statistical areas with extensive technical assistance, including from the Fund. Core data are provided on a timely basis. Mongolia is participating in the General Data Dissemination System (GDDS), and its metadata were posted on the Dissemination Standards Bulletin Board $(D S B B)$ in August 2000. A ROSC mission that visited Mongolia in May 2000 assessed data dissemination practices in Mongolia in relation to the TMF's GDDS. The data module of the ROSC for Mongolia was published on the IMF website in May 2001.

An STA mission to assist in the continuing process of improving national accounts visited Mongolia in February 2000. In conjunction with this mission, the authorities revised the annual GDP estimates for 1995-99 to incorporate the new source data and rebase to 1995 prices. Per the request of the National Statistical Office (NSO), STA has posted a long-term resident advisor on real sector statistics at the NSO since August 2001. The advisor has assisted the NSO in improving primary data collection and compilation systems for national accounts and price statistics.

An STA mission on consumer price statistics was fielded in September-October 2000. Based on the recommendations of this mission; the methodology utilized to compile the CPI was substantially revised in January 2001. The main revisions were as follows: (i) the CPI basket was updated based on the results of the 1999 Household Income and Expenditure Survey (HIES). The previous CPI contained 205 items while the revised CPI comprises 239 items; a deletion of four items and an addition of 38 new items.

Furthermore, a number of old items were redefined in order to better reflect current consumption patterns; (ii) the CPI weights were updated using the results of the 1999 HIES. The weights were updated again in March 2002 based on the 2000 HIES results; and (iii) the CPI was rebased from December 1995 to December 2000.

The authorities adopted systematic procedures for compiling annual fiscal reports for general government and each of the subsectors of general government, on the basis of the methodology proposed by an FAD/STA mission in March 2001. They also completed an inventory of all government bank accounts and instituted stricter standards for registering bank accounts for government agencies to allow the full reconciliation between government accounts data and banking data. However, adequate reconciliation of monetary and fiscal data and other mission recommendations have yet to be implemented. 
The May 2001 monetary and financial statistics mission found that the Bank of Mongolia (BOM) implemented most of the recommendations of the 1997 STA mission, including the valuation of monetary gold and the recording of Fund accounts in the BOM balance sheet.

In May 2001, the long-term resident advisor in balance of payments statistics completed a 26-month assignment to help develop the balance of payments statistics compilation system, which included the implementation of an enterprise survey. The results from the survey were reflected in the 1999 balance of payments data and also used to generate some partial international investment position estimates for the nonbank sector. A new report form on international transactions that pass through domestic banks was developed. Measures were also undertaken to conduct a survey of foreign embassies and international organizations. With the BOM's new regulation to require banks to report their international transactions effective from January 1, 2002, the accuracy and timeliness of BOP statistics are expected to be substantially enhanced. The annual enterprise survey of the BOM, if carried out and extrapolated in a proper way, is also expected to improve the data quality.

\section{Outstanding Issues}

- While some progress has been made in developing a national accounts framework, the quality of GDP estimates, particularly with respect to the current deflation methods for constant price estimates, could be improved further. A proper methodological treatment of arimal losses due to special harsh winters has to be finalized soon. Efforts are also needed to improve coverage of the informal sector and small-scale activity, especially in the services sector. Raw data could be refined with a view to producing reliable quarterly estimates of GDP. Furthermore, the construction of expenditure-based national accounts in constant price terms would serve as a useful check for the production side estimates.

- There has been limited progress in implementing the recommendation of the STA mission on consumer price statistics to compile a national CPI and to develop a producer price index, mainly due to resource and capacity constraints.

- There are a number of deficiencies in the data on wages and eamings. The development of labor market statistics through the establishment of quarterly sample surveys would help mitigate these shortcomings. The government conducted a survey of the civil service in May 2002, which would help to produce a detailed database on civil service employment and wages.

- The May 2001 STA mission identified a number of issues, including the coverage of monctary statistics, classification of a number of foreign on-lent loans, and recording of repurchase agreements on the treasury bills. The BOM is following up on the recommendations of the mission. 
- The quality of fiscal data--provided either for budgetary purposes or for publication in the GFS Yearbook - could be improved substantially, and improvements are underway in light of the FAD/STA mission of March 2001. Key weaknesses have been noncomprehensive coverage of the fiscal accounts, weaknesses in source accounting data, not documented compilation and consolidation procedures, lack of reconciliation between government accounts data and banking data at an aggregate level. These weaknesses are also present in monthly and quarterly reports, but compounded by the incomplete coverage of government accounts. Indeed, the poor quality of the quarterly data reported for publication in IFS has meant that the latest data published in IFS are for 1996 Q3. The planned application of an integrated government-wide chart of accounts will help resolve the underlying technical problems while ongoing treasury reforms should significantly improve accounting and reporting practices.

- Despite the improvement of BOP statistics' coverage and quality, firther improvement is needed in several areas. Particularly the data regarding remittances of migrant workers abroad and foreign direct investment need to be improved urgently.

\section{Publications}

The NSO publishes monthly and annual Statistical Bulletins in English and Mongolian. These bulletins include data on population, employment, national accounts, prices, household income and expenditure, central and local government revenue and expenditure, and external trade. The BOM publishes a monthly Statistical Bulletin (within 15 days of the end of the month, which includes summary statistics for the central bank, consolidated balance sheet of commercial banks, and interest and exchange rate data) and Annual Reports since 1993. All publications are available to the public. 
Mongolia--Core Statistical Indicators

(As of September 20, 2002)

\begin{tabular}{|c|c|c|c|c|c|c|c|c|c|c|c|c|}
\hline & $\begin{array}{c}\text { Exchange } \\
\text { Rates }\end{array}$ & $\begin{array}{l}\text { International } \\
\text { Reserves }\end{array}$ & $\begin{array}{l}\text { Reserve/ } \\
\text { Base } \\
\text { Money }\end{array}$ & $\begin{array}{l}\text { Central } \\
\text { Bank } \\
\text { Balance } \\
\text { Sheet }\end{array}$ & $\begin{array}{l}\text { Brosd } \\
\text { Money }\end{array}$ & $\begin{array}{l}\text { Interest } \\
\text { Rates }\end{array}$ & $\begin{array}{l}\text { Consumer } \\
\text { Price } \\
\text { Index }\end{array}$ & $\begin{array}{l}\text { Exports/ } \\
\text { Imports }\end{array}$ & $\begin{array}{l}\text { Current } \\
\text { Account } \\
\text { Balance }\end{array}$ & $\begin{array}{l}\text { Overall } \\
\text { Government } \\
\text { Balance }\end{array}$ & GDP/GNP & $\begin{array}{c}\text { External } \\
\text { Debt }\end{array}$ \\
\hline $\begin{array}{l}\text { Date of Latest } \\
\text { Observation }\end{array}$ & $\begin{array}{l}\text { Sept. } 19 \\
2002\end{array}$ & $\begin{array}{l}\text { Sept. 6, } \\
2002\end{array}$ & $\begin{array}{c}\text { Sept. 6, } \\
2002\end{array}$ & $\begin{array}{l}\text { Sept. } 6 \\
2002\end{array}$ & $\begin{array}{l}\text { Aug. 31, } \\
2002\end{array}$ & $\begin{array}{l}\text { Sept. } 4, \\
2002\end{array}$ & $\begin{array}{l}\text { Aug. } \\
2002\end{array}$ & $\begin{array}{l}\text { Aug. } \\
2002\end{array}$ & Q1 2002 & $\begin{array}{l}\text { Aug. } \\
2002\end{array}$ & 2001 & 2001 \\
\hline Date Received & $\begin{array}{l}\text { Sept. 20, } \\
2002\end{array}$ & $\begin{array}{l}\text { Sept. 11, } \\
2002\end{array}$ & $\begin{array}{l}\text { Sept. 13, } \\
2002\end{array}$ & $\begin{array}{l}\text { Sept. 13, } \\
2002\end{array}$ & $\begin{array}{l}\text { Sept. 20, } \\
2002\end{array}$ & $\begin{array}{c}\text { Sept. 11, } \\
2002\end{array}$ & $\begin{array}{l}\text { Sept. 11, } \\
2002\end{array}$ & $\begin{array}{l}\text { Sept. 12, } \\
2002\end{array}$ & $\begin{array}{l}\text { Aug. } 27, \\
2002\end{array}$ & $\begin{array}{l}\text { Sept. 12, } \\
2002\end{array}$ & $\begin{array}{c}\text { June 10, } \\
2002\end{array}$ & $\begin{array}{c}\text { May } 8 \\
2002\end{array}$ \\
\hline $\begin{array}{l}\text { Frequency of } \\
\text { Data }\end{array}$ & Daily & Weekly & Weekly & Weekly & Monthly & Weekly & Monthly & Manthly & Quarterly & Monthly & Annual & Annual \\
\hline $\begin{array}{l}\text { Frequency of } \\
\text { Reporting }\end{array}$ & Weckly & Weekly & Weekly & Weekly & Monthly & Weekly & Monthly & Monthly & Quarterly & Monthly & Annual & Annual \\
\hline Source of Data & BOM & BOM & вом & $\mathrm{BOM}$ & BOM & BOM & NSO & NSO & BOM & MOFE & NSO & MOFE \\
\hline $\begin{array}{l}\text { Mode of } \\
\text { Reporting }\end{array}$ & Electronic & Electronic & Electronic & Electronic & Electronic & Electronic & Electronic & Electronic & Electronic & Fax & Fax & Electronic \\
\hline Confidentiality & Unrestricted & Unrestricted & Unrestricted & Unrestricted & Unrestricted & Unrestricted & Unrestricted & Unrestricted & Unrestricted & Unrestricted & Unrestricted & Unrestricted \\
\hline $\begin{array}{l}\text { Ftequency of } \\
\text { Publication }\end{array}$ & Daily & Monthly & Monthly & Monthly & Monthly & Menthly & Monthly & Monthly & Quarterly & Monthly & Annual & Annual \\
\hline
\end{tabular}




\section{Mongolia-Fund Relations}

(As of August 31, 2002)

I. Membership Status: Joined: 02/14/1991; Article VIII

II. General Resources Account:

Quota

Fund Holdings of Currency

Reserve Position in Fund

II. SDR Department:

Holdings

IV. Outstanding Purchases and Loans: ESAF/PRGF Arrangements
SDR Million

51.10

51.03

0.07

SDR Million

0.03

SDR Million

33.75
Percent Quota

100.0

99.9

0.1

Percent Allocation

N/A

Percent Quota

66.1

V. Financial Arrangements:

$\begin{array}{lcccc}\text { Type } & \begin{array}{c}\text { Approval } \\ \text { Date }\end{array} & \begin{array}{c}\text { Expiration } \\ \text { Date }\end{array} & \begin{array}{c}\text { Amount Approved } \\ \text { (SDR Million) }\end{array} & \begin{array}{c}\text { Amount Drawn } \\ \text { (SDR Million) }\end{array} \\ \text { PRGF } & 09 / 28 / 2001 & 09 / 27 / 2004 & 28.49 & 4.07 \\ \text { ESAF/PRGF } & 07 / 30 / 1997 & 07 / 29 / 2000 & 33.39 & 17.44 \\ \text { ESAF } & 06 / 25 / 1993 & 06 / 24 / 1996 & 40.81 & 29.68\end{array}$

VI. Projected Obligatlons to Fund: (SDR Million; based on existing use of resources and present holdings of SDRs):

Principal

Charges/interest

Total

\begin{tabular}{rrrrr}
\multicolumn{5}{c}{ Forthcoming } \\
2002 & 2003 & $\mathbf{2 0 0 4}$ & $\mathbf{2 0 0 5}$ & $\mathbf{2 0 0 6}$ \\
2.4 & 6.1 & 4.9 & 4.0 & 4.0 \\
0.1 & 0.1 & 0.1 & 0.1 & 0.1 \\
2.5 & 6.2 & 5.0 & 4.1 & 4.1
\end{tabular}

\section{Safeguards Assessments}

Under the Fund's safeguards assessment policy, the Bank of Mongolia (BOM) was subject to a full safeguards assessment with respect to the PRGF arrangement that was approved by the Executive Board on September 28, 2001. An on-site safeguards assessment of the BOM was completed on March 5, 2002. Staff recommended that the BOM implement measures to strengthen its external audit mechanism and financial reporting framework. The BOM has so far implemented several of the recommendations. Staff continues to monitor the BOM's efforts to: (i) commit to the full adoption of International Accounting Standards (IAS) and to disclose its guarantees and pledges in its financial statements; (ii) disclose the fair value of derivatives in its net international reserve position and financial statements; and (iii) amend 
the central bank law to introduce independent oversight of BOM operations through an expanded Board that includes non-executive members.

\section{Exchange Arrangement:}

On May 27, 1993, Mongolia moved from a fixed exchange rate against the U.S. dollar to a floating exchange rate system. However, the BOM bas, at times, made active use of its intervention practices to maintain a stable nominal exchange rate vis-a-vis the U.S. dollar over extended periods of time. The official exchange rate is now set weekly on the basis of transactions in the interbank market. At end-August 2002, the official midpoint rate was Tog 1,116 per U.S. dollar.

\section{Article IV Consultation:}

The 1999 Article IV consultation (EBS/00/3) was concluded by the Executive Board on January 24, 2000 (SUR/00/14). Mongolia is on the standard 12-month consultation cycle.

\section{ROSC Assessments}

- ROSC, Data Module, May 4, 2001 (SM/01/144)

- ROSC, Fiscal Transparency Module, November 8, 2001 (SM/01/329)

\section{Recent Financial Arrangements:}

A three-year arrangement under the Enhanced Structural Adjustment Facility in an amount equivalent to SDR 40.81 million ( 80 percent of quota) with a first annual arrangement in an amount of SDR 18.55 million (36.3 percent of quota), was approved on June 25, 1993 (EBS/93/79). The second annual arrangement in an amount of SDR 11.13 million (21.8 percent of quota) was approved on November 23, 1994 (EBS/94/213). The ESAF arrangement lapsed on June 24, 1996.

A three-year arrangement under the ESAF/PRGF in an amount equivalent to SDR 33.4 million (65.4 percent of quota), with a first annual arrangement in an amount of SDR 11.13 million (21.8 percent of quota), was approved by the Executive Board on July 30,1997 . The first year arrangement lapsed on July 30, 1998. The second annual arrangement of SDR 14.8 million (29 percent of quota) was approved on June 16,1999 . The first review under that arrangement was completed in January 2000 and the arrangement lapsed on June 15, 2000. The ESAF/PRGF arrangement lapsed on July 29, 2000.

A new three-year arrangement under the PRGF in an amount equivalent to SDR 28.49 million ( 55.8 percent of quota), with the first year of the arrangement in an amount of SDR 12.21 million (23.9 percent of quota), was approved by the Executive Board on September 28, 2001. 


\section{Technical Assistance:}

Missions:

- Revenue Administration (FAD), September 2002

- Banking supervision (MAE), May 2002

- Review of treasury and intergovemmental fiscal reforms (FAD), August 2001

- Banking supervision and accounting (MAE), May-June 2001

- Money and banking statistics (STA), May 2001

- Government finance statistics (STA), March 2001

- Fiscal transparency and ROSC (FAD), March 2001

- Intergovernmental fiscal relations and budget reform (FAD), January 2001

- Visits by MAE peripatetic experts on banking supervision, payment system, monetary policy, and accounting and audit, November 2000 (ongoing).

- Consumer price statistics (STA), September-October 2000

- ROSC: data module (STA), May 2000

- Restructuring bonds and other securities (MAE), March 2000

- National accounts statistics (STA), February 2000

\section{Resident Advisors:}

- National accounts statistics (STA), August 2001-January 2003

- Treasury reform (FAD), June 1999-November 2002

- Balance of payments (STA), March 1999-May 2001

Technical assistance for the period May 1995-October 1999 is reported in Annex II of $\mathrm{EBS} / 00 / 3$.

\section{Resident Representative:}

Mr. Martin's term as resident representative was extended for a third year beginning midNovember 2001. 


\section{Mongolia-Relations with the World Bank Group ${ }^{1}$}

Mongolia became a member of the World Bank, IDA and IFC in February 1991. A Country Assistance Strategy (CAS) for 1998-2000 was approved by the Board on June 2, 1998. The primary goal of the CAS is to support the government through lending and nonlending services in completing the transition to a market-led economy, improve living standards, and reduce poverty.

Completed lending operations: The following credits have been fully disbursed and closed: An Economic Rehabilitation Credit (US\$30 million) and a Technical Assistance Credit (US\$5 million), both approved in December 1991; an Economic Transition Support Credit (US\$20 million), approved in October 1993, to finance critical imports and technical assistance for the mining and transport sectors; a Transport Rehabilitation Credit (US\$30 million), approved in May 1994, addressed key constraints in the transport sector, particularly by arresting the deterioration of the quality and quantity of transport services in railways, urban transport, trucking, and roads; the Poverty Alleviation for Vulnerable Groups Credit (US $\$ 10$ million), approved in July 1995, aimed to promote income-generating activities for the poor, raise basic education enrollment rates, reduce maternal mortality, and assist the disabled, particularly children; a Coal Project (US\$35 million), approved in May 1996, helped to upgrade operations and management of the Baganuur coal mine and financed training in mine operation, mine management, and feasibility studies; a Banking and Enterprise Adjustment Credit (US\$10 million) associated with the Banking, Enterprise and Legal Technical Assistance Credit (US\$2 million), approved in May 1997, aimed to support the government in implementing its structural reform programs in the financial and enterprise sectors and in developing the legal framework for commercial and financial transactions.

Ongoing lending operations: The current portfolio comprises nine active projects. The Ulaanbaatar Services Improvement Project is helping to upgrade water supply and sanitation facilities in the capital's low-income ger districts; it became effective in July 1998. A Fiscal Technical Assistance Project was approved by the Board in June 1998 and became effective in February 1999. This project supports the development of an efficient and transparent government financial management system and the introduction of a value-added tax to strengthen the government's revenue base. A Private Sector Development Credit was approved in May 1999 and became effective in December 1999. It supports the development of Mongolia's private enterprise and financial sectors. A Financial Sector Adjustment Credit (US\$32 million) was approved in May 2000 to support policy reforms required to implement a medium-term strategy for financial sector reform. The Transport Development Project (US\$34 million), approved in March 2001, is supporting the reconstruction and upgrading of roads in Mongolia's central and western regions to provide rural communities with better access to health, ectucation and social services. The Energy Project (US\$30 million), approved in May 2001, will reduce system losses and improve revenue collection in electricity distribution companies, and improve the reliability and financial sustainability of electricity distribution companies. A Learning and Innovation Lending (LIL) Credit

\footnotetext{
' Prepared by World Bank staff; any questions relating to Mongolia's relations with the Bank can be addressed to Ms. Vera Songwe (Tel. 473-3425) or Mr. Zafar Ahmed (Tel. 473-4699).
} 
(US\$5 million), approved in December 2001, is supporting a Legal and Judicial Reform Project. The Financial Capacity Development Project (US\$5 million), approved in June 2002, will support institutional capacity-building of the Mongolian banking sector to reduce systemic risks and enhance financial intermediation. The Sustainable Livelihoods Project (US\$19 million), also approved in June 2002, will support the first phase of the development and implementation of a nonwelfarist national anti-poverty strategy to foster secure, sustainable livelihoods.

Future lending operations: Future IDA lending will continue to concentrate on supporting macroeconomic stabilization and structural adjustment programs, investment projects, and technical assistance. Credits are being proposed in support of capacity building for economic management, developing urban infrastructure, and supporting the government's poverty reduction strategy.

\begin{tabular}{|c|c|c|c|}
\hline & \multicolumn{3}{|c|}{$\begin{array}{l}\text { World Bank: Credit Approvals and Disbursements } \\
\text { to Mongolia, FY 1992-2002 } \\
\text { (In millions of U.S. dollars) }\end{array}$} \\
\hline & $\begin{array}{c}\text { Credit } \\
\text { Approvals }\end{array}$ & $\begin{array}{c}\text { Credit } \\
\text { Disbursements }\end{array}$ & $\begin{array}{l}\text { Undisbursed Balance at } \\
\text { the end of the Fiscal Year }\end{array}$ \\
\hline FY92 & 35.0 & 15.6 & 19.4 \\
\hline FY93 & 0.0 & 12.7 & 6.7 \\
\hline FY94 & 50.0 & 15.2 & 41.5 \\
\hline FY95 & 0.0 & 8.4 & 33.1 \\
\hline FY96 & 45.0 & 11.9 & 66.2 \\
\hline FY97 & 12.0 & 11.8 & 66.4 \\
\hline FY98 & 21.7 & 34.6 & 53.5 \\
\hline FY99 & 12.0 & 16.0 & 47.0 \\
\hline FY00 & 32.0 & 13.3 & 65.5 \\
\hline FY01 & 64.0 & 10.9 & 113.5 \\
\hline FY02 & 28.7 & 23.3 & 125.7 \\
\hline
\end{tabular}

Nonlending services: Three Country Economic Memoranda (CEMs-1991, 1994 and 1997) bave been distributed to the Board. An Energy Sector Review, a report on Prospects for Wheat Production, and a National Environmental Action Plan were completed in FY95. A Poverty Assessment and a Public Enterprise Review were completed in FY96. A report on the consequences of large-scale privatization, prepared in collaboration with the University of Maryland, was completed in early 1998. A Transport Strategy Study was completed in FY99. World Bank staff participate regularly in PRGF missions. The World Bank opened an office in Ulaanbaatar in June 1998. The first Country Portfolio Performance Review was beld in June 1999 and a second one is being completed. Current nonlending services include, a new public expenditure review and notes on trade policy, the copper sector, and publicprivate infrastructure issues. A poverty update and participatory Living Standard Assessment 
have been completed as well as an Environmental Monitor. Mongolia is now part of the World Bank's GDLN (Global Development Learning Network) system.

Aid coordination: The World Bank continues to play a strong role in aid coordination. Six Assistance Group Meetings of donors took place in Tokyo since 1991, co-chaired by the World Bank and the Government of Japan. The seventh meeting was beld in Ulaanbaatar in June 1999. The Mongolia Consultative Group Meeting, chaired by the World Bank, was held for the first time in Paris in May 2001, and the second Consultative Group meeting, co-chaired by the World Bank and the govemment, was held in Ulaanbaatar in July 2002 . In addition, the World Bank (IDA, FIAS, IFC and MIGA) is assisting the government with the promotion of Foreign Direct Investment (FDI). The first Investors' Conference on oil, gas and mining was held in Ulaanbaatar in June 1997, and the second on agro-industry and tourism took place in Ulaanbaatar in June 1998.

IFC: Mongolia is part of IFC's Extending Reach Program, an initiative to promote private sector development and investment in selected countries where difficult country conditions have constrained IFC activity. As part of this program, IFC invested in a small leather garmenting operation and the banking sector, and is currently considering projects in the tourism and financial sectors. IFC has also mobilized trust funds to conduct technical assistance in developing a tourism development program and in helping draft Mongolia's leasing law. IFC has assisted in conducting two foreign investment seminars to promote FDI. IFC's investment strategy in Mongolia is to provide long-term financing to private companies, improve the investment framework in the country, and assist in attracting technical know-how and foreign investment.

MIGA: Mongolia signed the MIGA convention in 1991 and ratified it the following year. MIGA will be able to assist the country in atracting foreign investment through its marketing and guarantee activities. MIGA has provided TA to the Board of Foreign Investment in investment promotion.

WBI: The World Bank Institute, the World Bank's external training division, has organized a number of seminars and courses in Mongolia as part of its Central Asia program. Courses included economic management, business valuation, financial sector development, and social sector reform. 


\section{Mongolia-Relations with the Asian Development Bank}

Mongolia became a member of the Asian Development Bank (ADB) in February 1991. ADB operations in Mongolia have been guided by its Country Operational Strategy (COS). The first COS covering 1994-99 was prepared in 1994. It was aimed at facilitating Mongolia's transition to a market economy by (i) creating an environment in which a competitive efficient market economy can flourish; (ii) developing the human resources and skills necessary for a market economy; and (iii) developing the infrastructure needed for a market economy. In line with the Poverty Reduction Strategy approved by the ADB Board in 1999, ADB entered into a Poverty Partnership Agreement (PPA) with the Government of Mongolia in 2000. Within the framework of the PPA and built on the lessons learned during the period 1994-99, ADB formulated in May 2000 its new COS for 2000-05. The new COS places poverty reduction at the highest level of importance to be achieved through pro-poor interventions that foster private sector-led economic growth and good governance. The new $\mathrm{COS}$ is aimed at fostering economic growth and combat poverty by switching the main mechanism for growth generation from public sector investments in infrastructure to employment-generating investments aimed at engaging the private sector. However, the COS also provides that support for road sector investment would be considered if the contribution of the sector to reducing poverty and promoting human development can be established. Accordingly, ADB currently focuses its operations on the six core sectors, namely, finance, public sector, social sector, agriculture, urban development and road.

In March 2002, ADB and the Government conducted the second joint annual review of the implementation of PPA. The PPA annual review confirmed that Mongolia is on a right track towards achieving the Millennium Development Goals. Good progress has been made in addressing the non-income poverty and achieving the goals of human development, particularly in terms of reducing infant and under-five mortality, improving health care and school enrollment. The bottleneck for poverty reduction lies with staggering economic growth unable to create sufficient employment or ensure a steady improvement of income, particularly the income of the poor. Therefore, grater emphasis on accelerating economic growth has been recommended.

ADB also has a window - the Private Sector Group (PSG)-for private sector operation without government guarantee. The PSG is currently working with the International Finance Corporation in providing assistance to the Government in the privatization of selected banks to supplement ADB's public sector interventions in the financial sector.

By early July 2002, the ADB had approved 29 loans from the Asian Development Fund (ADF) totaling US\$504.4 million. In addition, by that date, the ADB had approved 97 technical assistance (TA) grants amounting to US\$48.9 million. ADB has taken a lead role in several key sectors (e.g., policy and institutional reforms in the agriculture sector, public administration reforms, education, health, finance, roads, telecommunications, power,

${ }^{1}$ Prepared by Asian Development Bank staff. 
air navigation, and housing). In the second half of 2002 two loans are expected to get approval by the ADB Board: Education Sector Development Project (US\$68.5 million) and Integrated Development of Basic Urban Services in Secondary Towns (US\$26.5 million). Besides, the second tranch (US\$12.5 million) of the ongoing Governance Reform Program Ioan is to be released shortly after the passage of the Public Sector Management and Finance Law.

To ensure more effective use of development resources to achieve the development goals, ADB has recently adopted a new policy on performance-based allocation of its concessional ADF resources. According to this new policy, from 2002 onward, ADB will allocate the ADF resources to its eligible member countries including Mongolia, based on a country performance assessment. The country assessment focuses on major indicators concerning sustainable economic growth, socially inclusive development, governance and public sector management, and portfolio performance. For 2002, in line with the aforementioned new policy, ADB's lending level to Mongolia has been determined through country performance assessment with US\$32-34 million as the base case lending scenario. As a parallel support to its lending operation, $\mathrm{ADB}$ will endeavor to provide annually about US $\$ 3.1$ million technical assistance grant to Mongolia, mainly for project preparation, and activities directly related to reduction of poverty and promotion of good governance. A high case scenario may go up to US\$40 million subject to the country's performance to be evaluated against updated triggers.

The ADB has regularly participated in Mongolia Consultative Group meetings and coordinated its operations with the Fund, the World Bank and other donors. At the Ninth Assistance Group Meeting held in Ulaanbaatar in July 2002, the ADB was the lead discussant on governance and poverty issues. Through this and other forums, the ADB will continue to be actively involved in policy dialogue with the government, particularly with regard to continuing of reforms in (i) the promotion of good govemance in formulating effective policies and establishing efficient institutions; (ii) public sector management and finance which will lay a foundation for effective macroeconomic management; and (iii) the financial sector, to provide affordable financing services badly needed for increased private sector investment and production efficiency. The ADB will also continue to assist Government in strengthening its capacity in aid coordination, and planning and management of public investments. ADB's effectiveness in delivering its program of assistance to Mongolia has been strengthened with the official opening and full operation of a Resident Mission in August 2001.

In March 2002, Mongolia was accepted as a full member of the ADB supported sub-regional cooperation for the Central Asian Republics and the People's Republic of China (PRC). This sub-regional cooperation will provide Mongolia with a new dimension to participate in regional cooperation on a wider geographic basis. Started with a moderate program in 2000 , ADB has assisted Mongolia and PRC to establish a very effective institutional framework to promote and coordinate between the two countries. Cooperation in transportation, trade and investment and environmental management has been identified as a common priority. 


\section{INTERNATIONAL MONETARY FUND}

EXIETRNAL

Public Information Notice (PIN) No. 02/130

November 14, 2002
International Monetary Fund

$70019^{\text {th }}$ Street, NW

Washington, D. C. 20431 USA

\section{IMF Concludes 2002 Article IV Consultation with Mongolia}

On October 25, 2002, the Executive Board of the International Monetary Fund (IMF) concluded the Article IV consultation with Mongolia. ${ }^{1}$

\section{Background}

Mongolia has made great strides since it initiated its transition to a market-based economy in the early 1990s, but it continues to face important challenges. Good progress toward promoting macroeconomic stability and market-oriented reforms resulted in a recovery from the collapse in output suffered during the early 1990s. However, the government's large recourse to deficit financing in the context of a generalized weakening of fiscal governance led to an unsustainable build-up of public debt. With the political consensus for privatization and reform weakening in the late 1990s, the prospects for sustainable economic growth diminished. The current government that took office in August 2000 embarked on a new adjustment program aimed at restoring macroeconomic stability and reinvigorating the reforms required to promote a more rapid pace of private sector-led growth.

Domestic economic performance was mixed during 2000-01 and the first half of 2002. The severe winters of 2000-01 took a heavy toll on output and rural incomes. Real GDP growth is officially estimated to have declined to about 1 percent a year in 2000-01, despite robust domestic demand in the industrial and service sectors. Inflation rose to $11 \frac{1}{2}$ percent in 2000 , as the effects of weather-related decreases in food supplies and higher public utility tariffs were compounded by a 25 percent general increase in civil service wages. However, inflation fell

'Under Article IV of the IMF's Articles of Agreement, the IMF holds bilateral discussions with members, usually every year. A staff team visits the country, collects economic and financial information, and discusses with officials the country's economic developments and policies. On return to headquarters, the staff prepares a report, which forms the basis for discussion by the Executive Board. At the conclusion of the discussion, the Managing Director, as Chairman of the Board, summarizes the views of Executive Directors, and this summary is transmitted to the country's authorities. 
back to 8 percent in 2001 and inflationary pressures continued to decline in 2002, as the togrog remained stable vis-à-vis the U.S. dollar and domestic food prices eased. The real effective exchange rate of the togrog appreciated by 9 percent in 2001, before leveling off in 2002 , thus reverting to its level as of 1998 .

The key challenge for fiscal policy has remained to promote fiscal sustainability. While continuing pressures on outlays for public wages, goods and services, and domestic capital expenditure pushed the ratio of government expenditure to GDP to well over 40 percent in 2001, an offsetting surge in government revenues, reflecting in part the effects of a package of tax increases adopted under the 2001 budget, helped reduce the overall fiscal deficit to about $51 / 2$ percent of GDP in 2001 . Following the introduction of a number of reform measures to improve fiscal transparency and accountability, including fiscal data quality and reporting, the stock of government arrears declined by $1 \% \frac{1}{2}$ percentage points of GDP during 2001. Reflecting also favorable valuation effects, the stock of government debt (excluding the large stock of unresolved pre-1991 debt to Russia) fell from 100 percent of GDP in 1999 to $871 / 2$ percent of GDP in 2001. However, fiscal developments during 2002 have led to some reversal of the recent gains, as government wages and pensions were raised by an average rate of 20 percent from October 2002. In the absence of a credible civil service and pension reform strategy, existing plans to grant further large increases in government wages and pensions in 2003 and 2004 against the background of weakening prospects for revenue growth could pose a serious threat to fiscal sustainability.

Monetary and credit aggregates have risen sharply over the last two years. To a large extent, these developments reflect the welcome effect of an increase in confidence in the banking system as it continues to rehabilitate itself following the banking system crises of the 1990s. In these circumstances, monetary management by the Bank of Mongolia (BOM) has had to focus increasingly on keeping the growth of reserve money within a prudent range through the placement of BOM bills. Despite this effort, reserve money growth has accelerated from $81 / 2$ percent in 2001 to a year-on-year rate of more than 20 percent as of August 2002 , while the year-on-year rate of growth of credit to the private sector has remained at more than 100 percent.

Mongolia's overall balance of payments has recorded significant surpluses over the last two years, but its external position remains vulnerable. Exports rose briskly in 2000 under the impetus of rising world prices for copper and cashmere exports, but they leveled off in 2001, as the earlier improvement in the terms of trade was largely reversed and China imposed a ban on exports of raw materials of animal origin following the outbreak of foot-and-mouth disease in Mongolia. While import growth also rebounded in 2000 , it was subdued during 2001 . With receipts from emigrants' remittances reported to remain buoyant, the current account deficit is estimated to have been kept within a range of 51/2 to $7 \frac{1}{2}$ percent of GDP in 2000-01, which could be comfortably financed with the help of the existing pipeline of concessional external loans. Gross international reserves have risen steadily to a level of more than US\$200 million or the equivalent of about 14 weeks of imports at end-2001. The stock of Mongolia's post-1991 external debt, which consists primarily of government debt secured on concessional terms, declined to 83 percent of GDP in 2001 and the debt service ratio has so far remained manageable. However, continuing heavy reliance on foreign assistance to finance a large 
current account deficit makes the economy highly vulnerable to changes in donor and investor sentiment. Moreover, a settlement has yet to be reached on the large stock of pre-1991 convertible ruble debt (equivalent to 10 times Mongolia's GDP), which could have sericus implications for Mongolia's future debt service burden and external sustainability.

The government is making sustained efforts to implement its structural reform program. In the area of public sector management, the reforms to rationalize intergovernmental fiscal relations regarding VAT and other tax receipts have been largely completed. However, there has been no tangible progress in the key area of public administration reform, and the implementation of measures to shift all government deposits to a Treasury Single Account has been slower that expected. In the areas of bank reform and public enterprise privatization, notable progress has been made in the last two years, including through the continuing rehabilitation of the Agricultural Bank, the ongoing strengthening of bank supervision, and the recent privatization of the Trade and Development Bank, which is expected to be finalized by end-2002. However, the privatization of other large enterprises which are still carrying out loss-making quasi-fiscal activities has been delayed, while the energy sector's persistent financial imbalances continue to pose a threat to medium-term fiscal and external sustainability.

\section{Executive Board Assessment}

Executive Directors recognized Mongolia's achievements in its transition to a market-based system, which-despite harsh climatic conditions-included a decline in the rate of inflation to the single-digit range, a significant buildup of international reserves, a recovery of output from the collapse suffered in the early 1990 s, and progress in institutional and other reforms.

Directors considered that, despite these achievements, Mongolia faced daunting challenges in its efforts to promote robust growth, reduce poverty, and achieve fiscal and debt sustainability. These challenges have been exacerbated by the pressures on government spending, which have led to a large buildup of external public debt, and heightened the economy's external vulnerability. Considering the weak output growth during 2000-01, Directors were concerned that emerging macroeconomic imbalances could threaten to undermine the prospects for sustainable, pro-poor growth in the period ahead.

Directors stressed that enduring fiscal consolidation will be essential to place the public debt on a sustainable path, improve the operation of monetary and exchange rate policies, and facilitate private sector-led growth. A sustainable fiscal position will require a rationalization of public expenditures to make room for essential public investment, basic social services, and safety nets for the poor, while reducing over time the high tax burden. In this context, Directors cautioned that the authorities should ensure that further large increases in civil service wages and pensions do not jeopardize the attainment of a sound fiscal position. They therefore welcomed the authorities' decision to suspend the increases proposed in the 2003 draft budget, while taking early steps to adopt an effective civil service and pension reform strategy, with technical assistance from the World Bank.

Directors encouraged the authorities to build on recent progress toward improving fiscal transparency and accountability in the period ahead, in line with the recommendations of the 
Fund's Fiscal Affairs Department. In this connection, they welcomed the recent decision to reincorporate into the budget for 2002 the operations of entities that are slated to be privatized but which continue to conduct quasi-fiscal operations. Steadfast implementation of the government's re-phased treasury reform program, including through its timely extension to the social security system, was also underscored.

Directors commended the BOM for its track record in containing inflation. They noted that the recent rapid expansion of the monetary and credit aggregates suggested a return of confidence in the banking system. However, they cautioned against an excessive easing of monetary conditions, and considered that more decisive steps might need to be taken in the period ahead to control liquidity. In an environment of rapid credit expansion, Directors encouraged the BOM to tighten overall bank supervision, particularly the enforcement of loan classification and provisioning standards. They welcomed the recent distribution to banks of new anti-money laundering recommendations in line with the Financial Action Task Force guidelines, and looked forward to legislation that would require stricter reporting of questionable accounts, and prompt implementation of United Nations Resolutions in this area. In addition, to improve the transparency of its own operations, the BOM was urged to adopt and implement fully International Accounting Standards, and to continue implementing the recommendations in the recently completed safeguards assessment.

Directors observed that relatively large and persistent inflows of official and private capital in recent years, together with the BOM's intervention practices, may have exerted upward pressure on the real exchange rate. They noted that future developments in the exchange rate would need to be monitored closely in order to ensure that the competitiveness of the country's export sector and the authorities' efforts to diversify the economy are not adversely affected.

Directors encouraged the authorities to persevere in their efforts to establish a competitive, market-oriented economy, while maintaining a vibrant rural sector. They welcomed, in particular, the rehabilitation of the Agricultural Bank, which had enabled the government to offer it for privatization ahead of schedule, and considered the privatization of the Trade and Development Bank to be an important step in the further development of an efficient banking system in Mongolia. Directors urged the authorities to address quickly the problems of other large enterprises that still carry out loss-making quasi-fiscal activities, including in the important energy sector.

Directors expressed concern about the size of Mongolia's external debt burden and debt service costs. In these circumstances, they stressed that prudent fiscal and debt management policies as well as the avoidance of external public borrowing on nonconcessional terms are essential to ensure external viability over the medium term. Directors also stressed the importance of maintaining orderly relations with all creditors, and taking prompt action to resolve outstanding claims. To promote export-led growth and investment, the authorities were encouraged to streamline Mongolia's trade and investment regime further by simplifying customs administration, licensing, and regulations as well as by taking steps to ensure that national laws and regulations are enforced on a nondiscriminatory basis. 
Directors recognized the progress made in developing Mongolia's statistical base in recent years. They encouraged the authorities to continue their efforts to improve the quality and reliability of real sector, fiscal, and balance of payments data,

Directors welcomed the authorities' willingness to reconsider their wage and pension policies in consultation with the Fund and Bank staffs, and looked forward to prompt agreement on a sound policy framework that could pave the way for the completion of the Poverty Reduction and Growth Facility review. Directors noted the ongoing progress toward the development of a Poverty Reduction Strategy Paper (PRSP) and encouraged the authorities to take timely steps to prepare a full PRSP.

Public Information Notices (PINs) are issued, (l) at the request of a member country, following the conclusion of the Article IV consultation for countries seeking to make known the views of the IMF to the public. This action is intended to strengthen IMF surveillance over the economic policies of member countries by increasing the transparency of the IMF's assessment of these policies; and (ii) following policy discussions in the Executive Board at the decision of the Board. The Staff Report for the 2002 Article IV Consultation with Mongolia is also available. 
Nomina I GDP (2001): $\$ 1030$ million

Population (2001): 2.37 million

Quota: SDR 51.1 million

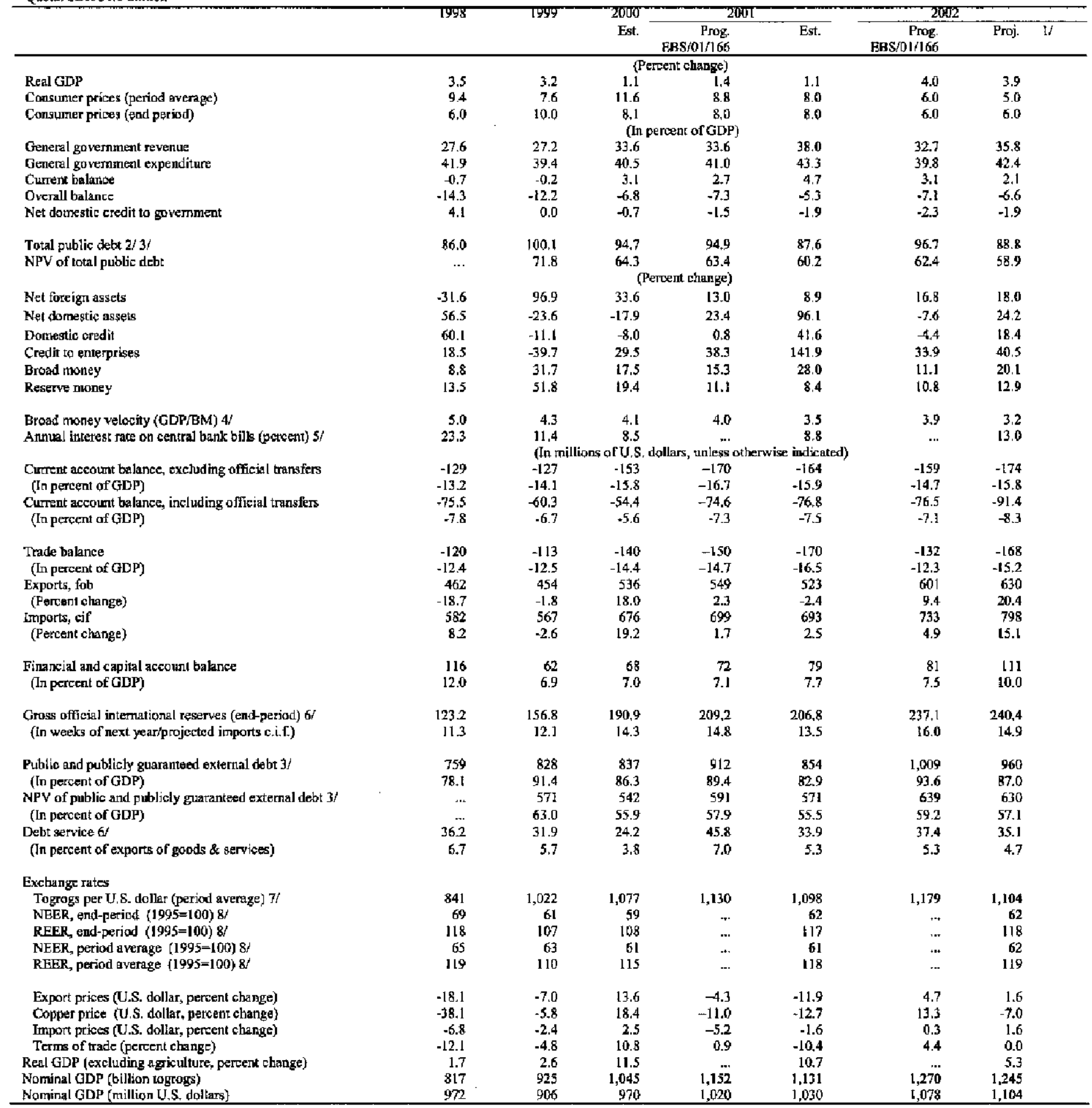

Sounce: Mongolian authorities; and IMF staff ectimates and projections.

I/ Staff projections, based on the assumption that the authorities implement policies along the lines recommended by the staff tenm during its

last mission to Mongolia in June 2002.

2/ Includes IMF loans, guarantees and arrears.

$3 /$ Excludes unne solved claims by Russia estimated at $T R$ 10.5 billion.

$4 /$ Seasonally adjusted figures for beogd motey velociny from 1997 onwards.

$5 /$ Ammualized yield on end-period auction of 14-day bills. For 2002, as of end-July.

6) Beginning December 2000, includes commencial banks' foreign exchange deposits with the Bank of Mongolia.

7) For 2002, as of Jure.

8 For 2002, as of Apri1. 


\section{Statement by Michael J. Callaghan, Executive Director for Mongolia and Damba Baasankhnu, Assistant to Executive Director October 25, 2002}

\section{Key Points}

- Mongolia faces daunting challenges given its location and harsh climatic conditions, but has made commendable progress in a relatively short time in its transformation to a market economy.

- The relationship with the Fund has been important in assisting Mongolia in its transformation, and relations with the staff continue to improve. Mongolia greatly appreciates the advice and assistance it receives from the Fund.

- The authorities clearly recognize the importance of fiscal sustainability and have acted accordingly, as evidenced by the recent trend of overall fiscal consolidation from 14.3 percent of GDP in 1998 to 6.8 in 2000 and further to 5.3 percent of GDP in 2001.

- In terms of the key concern raised by staff, namely the prospect of further increases in public sector wages and pensions along with an ambitious downsizing of the civil service, the authorities have advised that they will suspend the planned increases in wages and pensions in 2003 and will review the savings options in consultation with the World Bank and the Fund.

- The authorities have agreed to the publication of the staff report.

The staff report provides a comprehensive overview of the economic and financial situation in Mongolia, as well as a frank assessment of some of the challenges the country faces, with the emphasis very much on the challenges in the area of fiscal policy.

Directors who attended the Board retreat in December 2001 may recall that Jeffrey Sachs was very critical of a previous Fund staff report on Mongolia, stating that its focus was primarily on detailed budgetary issues and failed to take into account the daunting challenges the country faces in terms of its transition to a market based system, its land-locked geographic position, as well as its harsh climatic conditions.

\section{Many challenges bnt much progress with the assistance of the Fund}

With Sachs' comment in mind, it is important to recall the enormous economic and political transformation the country has undertaken in a relatively short period. Moreover, it is also 
relevant to note that Mongolia's economic performance has been very favorable compared with other transition economies, notwithstanding having to cope with a series of extreme climatic shocks. This latter aspect is highlighted in the Selected Issues Paper.

Another key aspect is that the Fund has played an important role in the development of the Mongolian economy, and the relationship between the authorities and the staff team has continued to improve in recent years. It would be unfortunate if a contrary impression was given by some of the frank comments in the staff paper.

The authorities' responsiveness to Fund staff views is evidenced by the fact that the government introduced a supplementary budget in 2002 which, in accordance with staff advice, reincorporated into the accounts 26 social sector entities that were previously excluded because they were scheduled to be privatized. The revised overall deficit for 2002 contained in the supplementary budget was $61 / 2$ per cent of GDP, again consistent with staff advice.

Most importantly, in terms of the key concern raised by the staff in this year's report, namely the prospect of further increases in civil service wages and pensions along with an ambitious downsizing of the public sector as proposed in the draft 2003 budget, the authorities have indicated that they will suspend the planned increase in wages and pensions in 2003 and will review the savings measures in consultation with the World Bank and the Fund. The authorities are keen to receive a World Bank mission as soon as possible to discuss the civil service reform package outlined in the draft 2003 budget.

\section{The challenge of maintaining public support for an ambitious reform program}

It also needs to be remembered that Mongolia is in the midst of implementing a fundamental restructuring of the economy, and we should never understate the political challenges involved in maintaining public support for such an ambitious reform agenda. This was emphasized in the recent Article IV consultations with the three major euro area economies. However, in the case of Mongolia it is also appropriate to recall that per capita income is only $\$ 425$ and the country faces major development needs in order to make substantial inroads into reducing poverty.

These factors are relevant in understanding the background to some of the recent decisions taken by the government. For example, the staff have focused on the rise in public sector wages and pensions. The authorities fully appreciate that any such increase in public sector wages and pensions must be consistent with the maintenance of a sustainable fiscal position. Towards this end, the draft 2003 budget involves an ambitious plan to reduce the size of the civil service by 16,500 and thereby generating annual savings of 1.1 per cent of GDP. The staff believe the public sector reform plans are excessively ambitious, but as noted previously, the authorities have indicated that they are keen to review the civil service reform measures in consultation with the World Bank and Fund. As noted above, the proposed increase in public sector wages and pensions in 2003 has been suspended pending the outcome of this review. 
It is important to recognize, however, that increases in public sector wages and pensions have been integral in maintaining support for the government's reform efforts as well as constituting an aspect of the social safety net. Public sector wages have increased by 52 per cent between 2001 and 1997, however, the average public sector wage in 2001 was still only $\$ 52$ per month. Yet as part of the reform to a market economy, subsidies have been removed from utility prices which has seen housing, heating and electricity prices rise by over 2.5 times and transport and communication prices rise by 61.1 per cent between 1997 and 2002. Ulaanbaatar is the coldest capital in the world and heating expenses constitute a very large proportion of any household budget. To put this in context, following recent energy price and tariff adjustments effective July 1, 2002, the utilities bill for an average farnily with four members living in a two bedroom apartment with centralized heating comprises 46 per cent of the family income.

In terms of the public pension, even after they increase effective 1 October 2002, the average monthly pension is only $\$ 23$. This hardly covers living expenses which have increased rapidly with recent energy tariff and price rises. In fact, the average pension is comparable with the poverty line recently established by the National Statistics Office. The number of households whose only source of income is the public pension or social assistance benefits comprises 21 per cent of total households.

\section{Recent economic developments are encouraging}

The staff report states that economic performance was mixed during 2000-01 and the first half of 2002 . Real GDP rose by 1.1 per cent in both 2000 and 2001 , compared with growth of 3.3 per cent in 1999 and 3.5 per cent in 1998. However the economy experienced exceptionally harsh winters in 2000 and 2001 which, when combined with drought conditions, resulted in substantial livestock losses, as outlined in Box 3 of the staff report. In addition, the advent of animal diseases had an adverse impact on stock levels as well as disrupting some of Mongolia's key export markets. Given that agriculture accounted for over half the growth in GDP in the 1990s, the underlying improvement in the performance of the economy was evidenced by the fact that notwithstanding the significant decline in agricultural output, growth in the secondary and tertiary industries kept overall GDP growth positive in $2000-2001$.

Mongolia has made significant progress in reducing inflation, notwithstanding the pressures on food prices as a result of drought conditions and stock loses. Inflation fell from 8 percent in 2000 to 5 per cent in 2002. The balance of payments position has improved and gross international reserves have reached the equivalent of 13.5 weeks imports. The overall budget deficit was reduced to 5.3 per cent of GDP in 2001 as a result of a significant improvement in revenue performance, changes in the intergovernmental tax sharing arrangements and lower then budgeted foreign-financed capital expenditure due to capacity restraints and slower preparation processes.

As noted in the staff report, the authorities are intent on maintaining orderly relations with all creditors and have reached agreement on a schedule of arrears on post-1991 debt to Russia. 
The report notes, however, that there appeared to be no allocation for the repayment of arrears in the 2002 supplementary budget. The authorities have advised that in accordance with the intergovernmental agreement for the repayments to be made in both cash and kind, as of October 23,2002, repayments of \$US2.75 million had been made to Russia over the course of 2002 and this will increase to \$US3.41 million by the end of the year. Mongolia has submitted a list of commodities which form part of the repayment arrangements and is waiting on a response from Russia.

\section{Improvements in the policy framework}

While the staff report concentrates on the challenges ahead, it is important to take stock of the major steps that have been taken to improve the overall policy framework, particularly fiscal management. These include strengthening tax administration, improving intergovernmental relations, enhancing fiscal reporting and accounting, introducing greater transparency and accountability, establishing a single treasury account, and adopting the long debated Public Sector Management and Finance Act. The establishment of a single treasury account system has had a positive impact on the governments cash management and reduced the costs/issuance of short-term treasury bills. It has also improved budget monitoring, facilitated the production of timely fiscal reports and enhanced the planning process.

Public sector arrears have been substantially reduced. Local governments have settled their payment arrears and central government entities are also close to settling all outstanding arrears. With the establishment of the treasury single account system, netting out operations are no longer undertaken. Inter-enterprise payment arrears have been one of the biggest problems hindering the cost recovery of state-owned enterprisers. In addition, the banking sector has been strengthened and competition enhanced and the performance of public sector utilities improved.

The implementation of the authorities privatization program is well under way. The largest commercial bank, the Trade and Development Bank, has been privatized, while the cashmere company, Gobi, was offered for sale but unfortunately no buyers have come forward. A new financial review of the company is being undertaken in order to improve the prospects for privatization. The Agricultural Bank, which provides banking services in rural areas, is being offered for privatization in advance of its scheduled date.

\section{The challenges ahead are clearly recognized}

While much progress has been made in transforming the Mongolian economy to a market based system, the challenges ahead remain daunting. The authorities clearly recognize the importance on building on the achievements to date, and as noted previously, many of the staff concerns stem from their belief that the government's reform strategy may be excessively ambitious.

The authorities agree with the staff about the need to reduce the role of the public sector in the economy, to improve the delivery of public services, to lower the tax burden, and create 
the environment for greater private sector activity. In pursuit of these objectives, and as mentioned previously, the government has developed an ambitious public sector reform plan in broad consultation with the parliament. The main objective is to reduce the dominance of the public sector in the economy. Measures being pursued include redefining the role of the state, reducing public employment through restructuring, commercialization and corporatization of public entities as well as the privatization of some entities, including in the higher education sector as well as institutions that are not considered to be undertaking the core functions government. It is also recognized that the banking sector needs to be further strengthened to ensure that the full range of financial services are available to support greater private sector activity.

Further steps are being taken to broaden the tax base and improve tax administration. The staff have expressed a concern that the uncertain benefits from the broadening of the tax base may not make up the losses resulting from reducing tax rates. After consultations with staff and analyzing the full impact of the envisaged tax reform measures outlined in Box 4, the authorities have decided to suspend any tax rate reducing measures until the expenditure reducing measures are implemented and associated savings have materialized.

\section{Public confidence has been restored in the banking system}

As highlighted in the staff report, there has been a return of public confidence in the banking system which was part of the reason for the strong growth in demand for money and the expansion in credit to the private sector. Nevertheless, the report also points out that the Bank of Mongolia ( $\mathrm{BOM}$ ) is in full agreement with the staff on the need to guard against excessively rapid growth of money and credit and has taken steps to raise the rates and placement of BOM bills. It is also worth highlighting that the BOM responded to concerns raised by the staff over the wording of the 2002 Monetary Policy Guidelines, by issuing a circular to commercial banks that it would not be offering new rediscounting facilities and preferential credit schemes to selected enterprises during 2002.

The BOM will continue to take steps to improve public confidence in the banking sector through strengthening its oversight and supervisory capacity and tightening the enforcement of prudent norms.

\section{Conclusion}

As noted previously, Mongolia greatly appreciates its relationship with the IMF and the advice and assistance it receives from the Fund. It places considerable importance on the current PRGF program and is working assiduously to ensure the successful conclusion of the first review. Towards this end, it is seeking a Fund mission to return to Mongolia as soon as possible. 